\title{
AVALIAÇÃO DO DESGASTE E DA RUGOSIDADE SUPERFICIAL DO ESMALTE BOVINO SUBMETIDO AO CLAREAMENTO E ESCOVAÇÃO SIMULADA
}

JULIANA FELIPPI DAVID E GOES DE AZEVEDO

Dissertação apresentada à Faculdade de Odontologia de Bauru da Universidade de São Paulo como parte dos requisitos para obtenção do título de Mestre em Odontologia, na área de Dentística Restauradora

(Edição Revisada) 


\title{
AVALIAÇÃO DO DESGASTE E DA RUGOSIDADE SUPERFICIAL DO ESMALTE BOVINO SUBMETIDO AO CLAREAMENTO E ESCOVAÇÃO SIMULADA
}

JULIANA FELIPPI DAVID E GOES DE AZEVEDO

\begin{abstract}
Dissertação apresentada à Faculdade de Odontologia de Bauru da Universidade de São Paulo como parte dos requisitos para obtenção do título de Mestre em Odontologia, na área de Dentística Restauradora
\end{abstract}

(Edição Revisada)

Orientador: Prof. Dr. Rafael Francisco Lia Mondelli 


\title{
DADOS CURRICULARES
}

\author{
Juliana Felippi David e Góes de Azevedo
}

Nascimento

16 de agosto de 1975

Naturalidade

Salvador - Ba

Filiação

1996-2001

2002-2003

2003-2005

Associações
Thales Olympio Góes de Azevedo Filho Sônia Maria Felippi de Azevedo

Curso de Graduação pela Faculdade de Odontologia da Universidade Federal da Bahia

Curso de Especialização em Dentística Restauradora pela Faculdade de Odontologia de Bauru da Universidade de São Paulo

Curso de Pós-Graduação em Dentística Restauradora, nível de mestrado pela Faculdade de Odontologia de Bauru da Universidade de São Paulo

CRO-Ba - Conselho Regional de Odontologia do estado da Bahia

ABO - Associação Brasileira de Odontologia

SBPqO - Sociedade Brasileira de Pesquisa Odontológica

GBPD - Grupo Brasileiro de Professores de Dentística 
"Não é o desafio que define quem somos nem o que somos capazes de fazer. O que nos define é o modo como enfrentamos esse desafio: podemos deitar fogo às ruínas, ou construir um caminho através delas, passo a passo, rumo à liberdade". Richard Bach 


\section{DEDICATÓRIA}

\section{Aos meus pais Thales Filho e Sônia,}

Vocês semearam o amor, a paciência e a perseverança em meu coração, Me apoiando em todos os momentos de minha vida, sendo os meus maiores incentivadores. Vocês me ensinaram a não desistir diante das dificuldades e a acreditar na minha capacidade de superá-las. Sempre decididos, otimistas e sensatos, nobres no caráter. Tudo o que sou e o que tenho devo a vocês.

Pai, você é o meu herói, minha inspiração, meu amigo, um exemplo.

Mãe, você é minha grande amiga, cúmplice, confidente.

Sinto muito orgulho de tê-los como meus pais. Amo muito vocês, obrigada!!!

\section{Aos meus irmãos Thales Neto e Guto,}

Vocês nunca terão a real idéia do quanto são importantes para mim. Obrigada por estarem sempre ao meu lado, compartilhando todos os momentos da vida. Amo vocês!

\section{Aos meus avós}

Pelo exemplo de vida, amor e persistência. Em especial a "vozinho" que, em vida, me apresentou aos fascínios do mundo acadêmico, sendo um dedicado professor. Obrigada Prof. Dr. Thales de Azevedo.

A vocês, com todo o meu amor, dedico este trabalho. 


\title{
AGRADECIMENTOS ESPECIAIS
}

\author{
A Deus, \\ "O senhor é o meu pastor, nada me faltará. \\ Em verdes prados ele me faz repousar.
}

Conduz-me junto às águas refrescantes, restaura as forças de minha alma.

Pelos caminhos retos Ele me leva, pelo amor do teu nome.

Ainda que eu atravesse o vale escuro, nada temereis, pois estais comigo. Vosso perdão e vosso báculo são o meu amparo.

Preparais para mim a mesa à vista de meus inimigos.

Derramais o perfume sobre minha cabeça e transbordais a minha taça. A vossa bondade e misericórdia hão de seguir-me por todos os dias de minha vida.

E habitarei na casa do senhor por longos dias" (Salmo 22/23 atribuído ao Rei Davi)

Obrigada por ter me presenteado com esta vida, por me fornecer às ferramentas necessárias para construção de minha felicidade, por toda benevolência, por me presentear com tantas alegrias. 
A todas as pessoas com as quais convivi durante esse período e que participaram de alguma forma na execução deste trabalho, com um simples sorriso ou com alguma ajuda, sempre fundamental na resolução dos problemas.

Ao Prof. Dr. Rafael Francisco Lia Mondelli, pela orientação prestada na execução deste trabalho, pelo incentivo e confiança que sempre me dedicou.

Ao Prof. Dr. José Mondelli, seu exemplo de amor e dedicação à profissão são inestimáveis, sendo uma inesgotável fonte de inspiração.

Ao Prof. Dr.José Carlos Pereira, pelo exemplo de humildade e dedicação, sempre com um conselho amigo.

Á Profa. Dra. Maria Teresa Atta pela amizade e exemplo de profissionalismo, tornando fácil e suave o dia-a-dia.

Ao Prof. Dr. Ricardo Marins de Carvalho pela transmissão de conhecimentos e agradável convívio.

Aos colegas de Pós-Graduação, Adilson, Adriana, Ana Carolina, Carla, Emerson André, Juliana, Maria Cecília, Miguel, Mônica, Patrícia, Rosana, Ticiane, pela amizade e convivência, encorajando-me sempre nos momentos difíceis e presentes nos momentos de alegria. Obrigada por estarem sempre acrescentando algo, para

que o curso se tornasse ainda mais rico. Principalmente à Débora, pelo companheirismo e amizade, por compartilhar o conhecimento, os pacientes e sua própria família.

Obrigada por confiar seus pensamentos, suas decepções e seus sonhos.

Em especial à Safira, pela companhia e amizade, pelo apóio nos momentos de estudo, decepções, tristezas, vitórias e alegria.

Por juntas acreditarmos que para realizar os sonhos, basta lutar por eles. 
Aos amigos do doutorado, Ana Raquel, Anderson, Anuradha, Eduardo, Diego, Fabiano, Flávia, Leonardo, Luiz, Margareth, Renato, Serginho, Terezinha, por dividirem os conhecimentos e as experiências. Em particular à Angélica, pela sinceridade e presteza em sempre ajudar, pelo espírito de companheirismo e amizade.

A todos os amigos conquistados em Bauru, em especial à Carla, Eduardo, Fernanda, Gabriiela, Ian, Juan, Linda, Marinelle, Taciana, por termos compartilhado inúmeros momentos de alegria.

Ao Luiz Gustavo, pelo convívio saudável, pela amizade e por toda a atenção e ajuda despendidas.

Aos professores e amigos da Bahia, Alessandra, Alexandre, Ceres, Francisco, Márcia, Marcos Alan, Maria Jacinta, Paula, Rebeca, Vagner, por despertarem em mim a consciência da vida acadêmica. E ao Dr. Walter Pires, por todo o incentivo.

A todos os meus amigos sempre sinceros e presentes, compartilhando a vida compreendendo a minha ausência e acima de tudo me ajudando nos momentos de incertezas. Em particular à Elisângela, Marcelle, Raquel, Taniesca, Vivian.

As minhas companheiras desde a infância, Alessandra, Edla, Francesca, Mariana, Patrícia, Renata, Perla, Viviane, agradeço por saber que sempre posso contar com vocês. A distância só provou a nossa verdadeira amizade.

A Fábia e Cláudia, por serem grandes amigas.

Aos meus afilhados Glorinha e Léo, fontes de inspiração.

A todos da minha família que, mesmo distantes, se fizeram presente. 


\section{AGRADECIMENTOS}

À Faculdade de Odontologia de Bauru da Universidade de São Paulo, na pessoa da sua Diretora Profa. Dra. Maria Fidela de Lima Navarro, pela a oportunidade em adquirir novos conhecimentos.

A todos os Professores do Departamento de Dentística, e Materiais Dentários, Prof. Dra. Maria Fidela de Lima Navarro, Prof. Dr. Eduardo Batista Franco, Prof. Dr. Carlos Eduardo Fransischone, Prof. Dr. Aquira Ishikiriama, Prof. Dr. Paulo Afonso Franciscone, Prof. Dr. Paulo Amarante de Araújo e Prof. Dr. César Antunes de Freitas, pelos ensinamentos transmitidos.

Aos funcionários da Dentística, Materiais Dentários e da Pós-Graduação, Nelson, Zuleica, Karen, Ziley, Rita, Ângela, Dito, Junior, Sandra, Neuza, Giane, Cleusa, Eduardo, pela cordialidade e disponibilidade com que sempre me atenderam, vocês se tornaram imprescindíveis na confecção deste trabalho.

Ao Prof. Dr. José Roberto Pereira Lauris, pela paciência em esclarecer a análise estatística deste trabalho.

À bibliotecária Valéria, pela revisão bibliográfica e aos demais funcionários da biblioteca pelas orientações cientifícas.

À professora Eloísa, pela presteza na leitura do presente trabalho.

À amiga Nádia, pela sua prestimosa ajuda neste trabalho.

À instituição de fomento CNPq, pelo apóio financeiro.

A todos, meus sinceros agradecimentos. 


\section{SUMÁRIO}

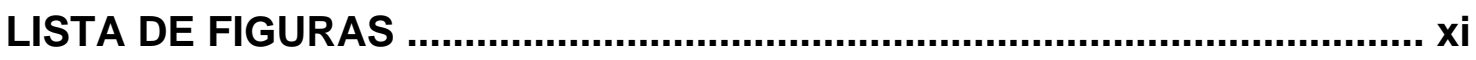

LISTA DE TABELAS ............................................................................ xiii

LISTA DE SIGLAS ................................................................................. xiv

RESUMO ............................................................................................ XVi

1. INTRODUÇÃO ......................................................................................... 01

2. REVISÃO DE LITERATURA ................................................................ 06

2.1. Evolução do clareamento ........................................................ 07

2.2. Clareamento Utilizando Agentes Fotossensíveis ..................... 11

2.3. Mecanismo de Ação dos Agentes Clareadores ......................... 16

2.4. Alterações Morfológicas no Esmalte após Clareamento ............ 21

2.5. Propriedades físicas do esmalte bovino .................................... 39

2.6.Formas de Avaliar o Desgaste e a Rugosidade Superficial do

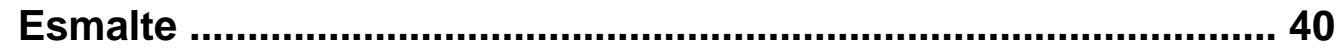

3. PROPOSIÇÃO .................................................................................... 49

4. MATERIAL E MÉTODOS ................................................................... 51

4.1. Material ............................................................................... 52

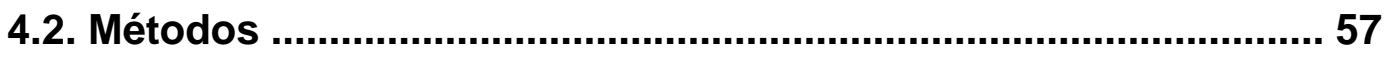

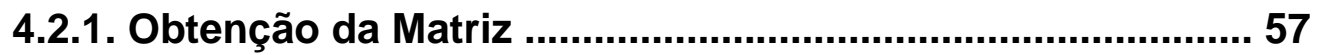

4.2.2. Confecção dos Espécimes .............................................. 58

4.2.3. Planificação e Polimento dos Corpos de Prova ................ 62

4.2.4. Determinação da Rugosidade Superficial Inicial .............. 64

4.2.5. Grupos a Serem Estudados ............................................. 65

4.2.6. Clareamento dos Espécimes ..........................................66 66

4.2.7.Determinação da Rugosidade Superficial Após o Clareamento ........................................................................ 69

4.2.8. Armazenamento dos Corpos de Prova ............................. 69

4.2.9. Procedimento de Abrasão ................................................. 69

4.2.10. Limpeza dos Corpos de Prova ...................................... 72

4.2.11. Determinação da Rugosidade Superficial Final .............. 72

4.2.12. Determinação do Desgaste Superficial .......................... 73 
4.2.13. Forma de Análise Estatística ......................................... 75

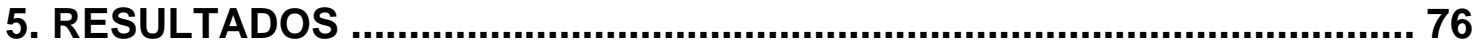

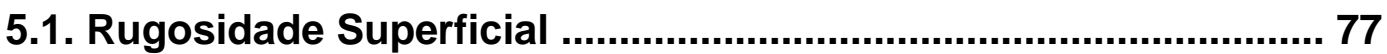

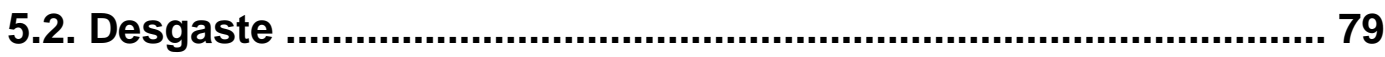

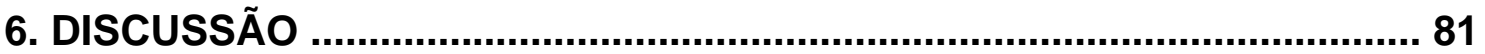

6.1. Discussão Relacionada às Técnicas de Clareamento ................ 82

6.2. Discussão Relacionada aos Métodos Empregada ...................... 84

6.3. Discussão Relacionada aos Resultados Encontrados ............... 90

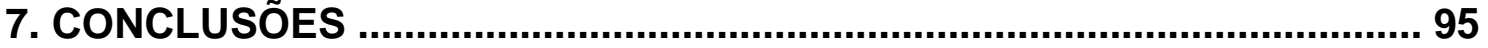

REFERÊNCIAS BIBLIOGRÁFICAS ........................................................ 97

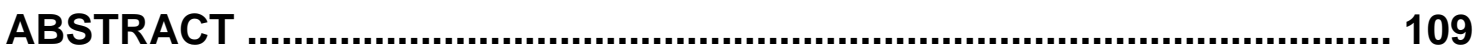




\section{LISTA DE FIGURAS}

FIGURA 1: Agente clareador à base de Peróxido de Hidrogênio 35\%, Lase Peroxide (DMC Equipamentos), composto de um frasco com peróxido de hidrogênio 35\%, um frasco com espessante, cuba para manipulação e espátula plástica.

FIGURA 2: Agente clareador à base de Peróxido de Carbamida 16\%, Whiteness Perfect (FGM Produtos Odontologicos), composto por bisnagas com o peróxido de carbamida à $16 \%$.

FIGURA 3: Aparelho de Luz Halógena Curing Light 2500 (3M Dental Products).

FIGURA 4: Aparelho Ultrablue IV (DMC Equipamentos) composto de luz híbrida à base de LED e Laser de Diodo.

FIGURA 5: Apresentação comercial do dentifrício e escova dental empregados

FIGURA 6: Projeto gráfico e medidas da cavidade, braços e plataforma da matriz empregada.

FIGURA 7: Matriz de aço inoxidável utilizada.

FIGURA 8: Matriz com os braços abertos, após remoção dos parafusos laterais.

FIGURA 9: Dentes incisivos centrais inferiores bovinos.

FIGURA 10: Visão lateral da face vestibular antes do aplainamento.

FIGURA 11: Visão lateral do aplainamento da face vestibular.

FIGURA 12: Seccionamento no sentido vestibulo-lingual.

FIGURA 13: Seccionamento no sentido mésio-distal.

FIGURA 14: Esquema do espécime obtido.

FIGURA 15: Espécimes obtidos após planificação do esmalte e preenchimento da câmara pulpar com resina composta.

FIGURA 16: Identificação do segmento controle com esmalte de unha.

FIGURA 17: Corpo de prova posicionado na matriz.

FIGURA 18: Politriz metalográfica Extec Losp.

FIGURA 19: Rugosímetro Hommel Tester T 1000.

FIGURA 20: Clareamento com luz híbrida. 
FIGURA 21: Clareamento com luz Halógena.

FIGURA 22: Clareamento com Peróxido de Carbamida à 16\%.

FIGURA 23: Clareamento com Peróxido de Carbamida à 16\%.

FIGURA 24: Máquina utilizada nos testes de escovação simulada.

FIGURA 25: Disposição do espécime em relação à barra metálica e à escova dental.

FIGURA 26: Injeção da solução (creme dental + água) durante o procedimento de escovação do espécime.

FIGURA 27: Ilustração esquemática mostrando o desgaste dos espécimes testados. (A) início da leitura feita pelo rugosímetro; (B) final da leitura e (C) desgaste máximo ocasionado pelo procedimento de abrasão.

FIGURA 28: Gráfico ilustrando as médias dos valores obtidos nos testes de rugosidade.

FIGURA 29: Gráfico ilustrando a média do desgaste. 


\section{LISTA DE TABELAS}

TABELA 1: Materiais utilizados e seus fabricantes

TABELA 2: Composição, lote, data de validade e indicação dos agentes clareadores empregados.

TABELA 3: Características dos aparelhos de luz empregados na ativação do agente clareador.

TABELA 4: Composição do dentifrício Colgate MFP

TABELA 5: Grupos estudados.

TABELA 6: Composição da saliva artificial.

TABELA 7: Valores das médias de rugosidade aritmética $(\mu \mathrm{m})$, iniciais, após clareamento, após escovação simulada, desvio padrão (DP) e análise estatística dos grupos estudados.

TABELA 8: Resultado da análise de variância para comparação entre as condições. Grupos (grupos estudados) e Fase (fase de tatamento - inicial, clareado e escovado).

TABELA 9: Resultado da média das rugosidades e análise estatística para comparação entre os grupos.

TABELA 10: Resultado da média das rugosidades e análise estatística para comparação entre as fases analisadas.

TABELA 11: Média do desgaste $(\mu \mathrm{m})$, desvio padrão e análise estatística dos diferentes grupos estudados. 


\section{LISTA DE SIGLAS, SÍMBOLOS E PALAVRAS DE LÍNGUA ESTRANGEIRA}

$$
\begin{aligned}
& \leq=\text { menor ou igual } \\
& \pm=\text { mais ou menos } \\
& \%=\text { por cento } \\
& \mathrm{dp}=\text { desvio padrão } \\
& g=\text { gramas }
\end{aligned}
$$

In situ (latim) = em sítio, no local (no caso, cavidade bucal)

In vitro (latim) = em laboratório

In vivo (latim) $=$ no ser humano

$\mathrm{ml}=$ mililitros

$\mathrm{mm}=$ milímetros

${ }^{\circ} \mathrm{C}=$ graus centígrados

$\mathrm{pH}=$ potencial hidogeniônico

$\mathrm{Ra}=$ rugosidade aritmética

$\mathrm{s}=$ segundos

$\min =$ minutos

$\mathrm{h}=$ hora

$\mu \mathrm{m}=$ micrometro

MEV = Microscopia Eletrônica de Varredura

MLP = Microscopia de Luz Polarizada

ESCA = Espectrocopia eletrônica para análise quimíca

MFP = Máximo Flúor Protetor

$\mathrm{HA}=$ halógena

$\mathrm{UB}=$ ultrablue

$\mathrm{N}=$ Newton

$\mathrm{H}_{2} \mathrm{O}=$ composição da água

$\mathrm{H}_{2} \mathrm{O}_{2}=$ composição do peróxido de hidrogênio

LED = Light Emitting Diodes

LASER = Light Amplification by Stimulated Emission of Radiation 


$$
\begin{aligned}
& \mathrm{nm}=\text { nanômetro } \\
& \mathrm{PH}=\text { peroxido de hidrogênio } \\
& \mathrm{PC}=\text { peroxido de carbamida } \\
& \mathrm{CP}=\text { corpo de prova }
\end{aligned}
$$


RESUMO

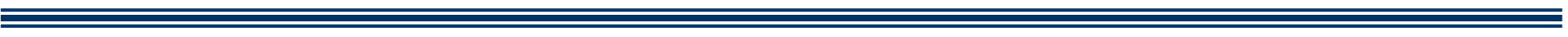




\section{RESUMO}

Este estudo avaliou o desgaste e a alteração de rugosidade superficial do esmalte bovino submetido a três diferentes técnicas clareadoras e escovação simulada. Fragmentos de esmalte com $1,5 \mathrm{~cm} \times 0,5 \mathrm{~cm}$ e altura de $0,4 \mathrm{~cm}$ foram obtidos. Metade dessa porção de esmalte recebeu tratamento clareador e escovação simulada, ficando a outra metade como controle. Foram polidos seqüencialmente e a rugosidade aritmética $(\mathrm{Ra})$ inicial determinada pela média $(\mu m)$ de 5 leituras com o rugosímetro Hommel Tester T 1000. Os espécimes foram divididos em quatro grupos $(n=10)$, de acordo com o tratamento empregado: G1= saliva artificial (controle); G2= peróxido de hidrogênio $(\mathrm{PH}) 35 \%$ (Lase Peroxide, DMC Equipamentos) ativado com luz híbrida (LED e laser de diodo) Ultrablue IV (DMC Equipamentos). O PH foi aplicado, aguardando-se 2 min para ser irradiado com a luz híbrida por 3 min e mantido sobre o espécime por mais 3 min, com 3 aplicações consecutivas; G3= PH 35\% ativado com luz halógena Curing Light (3M/ESPE Dental Products). O PH foi aplicado, com tempo de espera de 2 min, para ser irradiado com luz halógena por 30s, intervalo de 30s, até completar 3 min de ativação, sendo o agente mantido sobre o espécime por mais $3 \mathrm{~min}$, com 3 aplicações consecutivas; G4= clareamento com peróxido de carbamida (PC) 16\% (Whitenees Perfect 16\%, FGM) por 2h diárias durante 14 dias. Os espécimes foram imersos em saliva artificial pelo restante do tempo. Após o clareamento, a rugosidade ( $\mathrm{Ra}$ ) foi determinada e os corpos-de-prova armazenados em saliva artificial por 7 dias, com troca diária para remineralização, e submetidos a 100.000 ciclos de escovação simulada. Posteriormente, foram determinados a rugosidade final $(\mathrm{Ra})$ e o desgaste superficial, o qual foi verificado pela média de três leituras, utilizando a perfilometria através do rugosímetro Hommel Tester T 1000. As médias de rugosidade superficial foram submetidas à análise de variância a 2 critérios e teste de Tuckey que não detectou diferenças significantes entre os grupos para a rugosidade inicial e após clareamento. Após a escovação, houve diferenças significantes entre o grupo controle e os demais grupos, em que o G4 apresentou aumento significante da rugosidade em relação ao G2. As médias de desgaste 
foram submetidas à análise de variância e teste de Tuckey, onde o G1 apresentou menor desgaste que os demais grupos. As técnicas de clareamento dental empregadas na superfície de esmalte bovino proporcionaram aumento da rugosidade e do desgaste superficial, quando submetido à escovação simulada. 
1. INTRODUÇÃO 


\section{INTRODUÇÃO}

A capacidade de sorrir, inerente ao homem, o faz único e particularmente especial. O sorriso tem a função de comunicação e esse gesto apresenta muitos significados e conotações, sendo um sinal que enviamos às pessoas, disponibilizando a nossa capacidade de brincar, de nos unir e de nos aproximar delas. Pode ser um símbolo de alegria ou uma poderosa arma de sedução, mas antes de tudo, é a melhor demonstração de uma atitude favorável e positiva diante da vida. No entanto, muitas pessoas sentem-se envergonhadas em emitir esse tipo de expressão facial, por terem seus dentes fora dos padrões estéticos, comprometendo, inclusive, o seu convívio na sociedade.

Nas últimas décadas, uma das áreas da odontologia que mais vem crescendo está relacionada aos aspectos estéticos, uma vez que os pacientes procuram por tratamentos relacionados a uma boa aparência da dentição. Conseqüentemente, houve um grande avanço tecnológico na área de materiais restauradores estéticos e adesivos, bem como o surgimento e consagração de técnicas conservadoras como o clareamento dental. Sendo assim, cabe ao profissional conhecer e dominar os diferentes agentes clareadores, métodos de ativação, técnicas e seus efeitos sobre a estrutura dental, para que obtenha sucesso ao final do tratamento (HAYWOOD ${ }^{35}$, 1992; MONDELLI ${ }^{62}$, 2003; NAVARRO; MONDELLI ${ }^{64}$, 2002; REYTO ${ }^{69}$, 1998; SULIEMAN, et al. ${ }^{79}$, 2004).

A cor dos dentes, apesar de ser apenas um dos vários fatores que concorrem para o equilíbrio estético do sorriso, constitui o fator isolado mais importante por ser a desarmonia de cor mais imediata e rapidamente percebida do que as outras anomalias estéticas (HAYWOOD ${ }^{36}$, 1997). É muito importante que, durante a reprodução estética, o cirurgião-dentista saiba diagnosticar as causas da alteração de cor e indicar o clareamento antes de propor o procedimento odontológico adequado (GOLDSTEIN ${ }^{24}, 1997$; MONDELLI ${ }^{62}, 2003$ ), uma vez que o clareamento preserva as estruturas dentárias, quando comparado com técnicas mais radicais como o preparo de facetas ou coroas totais em resina ou cerâmica (McEVOY ${ }^{56}$, 1989). Dessa forma, os procedimentos que tornam os dentes mais claros fazem parte integrante do tratamento odontológico como um todo, minimizando ao máximo 
os danos causados nas intervenções clínicas (HAYWOOD ${ }^{36}, 1997$; KINGSBURY ${ }^{46}$, 1861; ZANIN et al. ${ }^{84}$, 2003). No entanto, expõe os tecidos duros do dente, bem como os tecidos moles, a riscos que devem e podem ser controlados ou evitados (NAVARRO; MONDELLI ${ }^{64}, 2002$ ).

Dentre as técnicas para o clareamento de dentes polpados, pode-se citar a técnica em consultório, idealizada por AMES em 1937, e a caseira idealizada por HAYWOOD; HEYMANN ${ }^{32}$ em 1989. Anteriormente, a técnica em consultório era realizada sob isolamento absoluto, onde se utilizava solução de peróxido de hidrogênio a 30\%, ativado com fonte de calor, em intervalos semanais. Mais recentemente, começaram a ser empregados os géis de peróxido de carbamida a $22 \%$ e $35 \%$, e o gel de peróxido de hidrogênio a 35\% fotossensível (GABER ${ }^{22}, 1997$; GOLDSTEIN $^{24}$, 1997; MONDELLI ${ }^{62}$, 2003; ZANIN et al. ${ }^{84}$, 2003). Para a técnica caseira é necessário confeccionar uma moldeira individual plástica em máquina a vácuo, através da qual o próprio paciente aplica, em sua casa, um gel à base de peróxido de carbamida a $10 \%, 15 \%$ ou $16 \%$, de acordo com as recomendações do dentista (HAYWOOD ${ }^{35}$, 1992; HAYWOOD; HEYMANN ${ }^{32}$, 1989; MONDELLI ${ }^{62}$, 2003).

O verdadeiro agente clareador é o peróxido de hidrogênio. O peróxido de carbamida decompõe-se em uréia e peróxido de hidrogênio, sendo soluções que penetram e se movem através do esmalte e da dentina devido ao seu baixo peso molecular. Embora não seja totalmente conhecido o mecanismo pelo qual os agentes clareadores atuam, o mais provável é que ocorra um processo de oxidação, sendo o peróxido de hidrogênio decomposto em $\mathrm{H}_{2} \mathrm{O}$ e $\mathrm{O}^{-}$, que atua sobre os pigmentos do esmalte e da dentina, levando substâncias complexas compostas de anéis de carbonos (pigmentos) a se converterem em substâncias abertas mais simples e mais claras (LYNCH et al. ${ }^{52}$, 1995; McEVOY ${ }^{56}, 1989$; RIEHL ${ }^{70}, 2002$ ).

O ressurgimento do clareamento de consultório em apenas uma sessão de atendimento ocorreu devido ao marketing relacionado à utilização de novos aparelhos e equipamentos por meio da emissão de luz, como a halógena, arco de plasma, LED (luz emitida por diodo) ou aparelhos a lazer de argônio, diodo, neodímio-YAG ou $\mathrm{CO}_{2}$ implicando na utilização de agentes em altas concentrações (GABER $^{22}$, 1997; GOLDSTEIN ${ }^{24}$, 1997; MONDELLI ${ }^{62}$, 2003; NAVARRO \& MONDELLI ${ }^{64}, 2003$, REYTO $^{69}, 1998$; ZANIN, et al. $\left.{ }^{84}, 2003\right)$. A solução do peróxido 
de hidrogênio a 30-35\% é depositada sobre o esmalte dental, sendo ativada de acordo com o sistema clareador empregado, por calor ou por radiação, incluindo os aparelhos de laser (GIOIA ${ }^{23}, 2000$; REYTO $\left.{ }^{69}, 1998\right)$.

A potencialização do gel clareador através da temperatura pode causar injúrias ao tecido pulpar (BOWLES; UGWUNERI ${ }^{11}$, 1987). As emissões fotônicas, como os laseres e os LED's, são radiações não ionizantes e concentradas que, ao serem absorvidas pelos tecidos com o qual interagem, resultam em efeitos fotoquímicos e mínimos efeitos fototérmicos, tendo como alvo moléculas escurecidas. Esses mecanismos geram um aumento mínimo de temperatura, sem dano ao tecido pulpar, pois aquecem o produto e não a estrutura dental (MONDELLI ${ }^{64}, 2003$; ZANIN et al. ${ }^{84}$, 2003).

Contudo, existem diversos relatos documentados na literatura afirmando que o uso indiscriminado dos peróxidos poderia afetar negativamente os tecidos duros e moles da cavidade bucal. Os efeitos notados quando do uso de agentes clareadores caseiros, em baixa concentração, geralmente se apresentam como depressões rasas, aumento de porosidades e leve erosão (BEM-AMAR, et al. ${ }^{9}, 1995$; BITTER $^{10}$, 1992; JOSEY et al. ${ }^{43}$, 1996; SHANNON, et al. ${ }^{76}$, 1993). Porém, quando do uso de agentes clareadores em maior concentração, observam-se alterações morfológicas severas na superfície do esmalte (HOSOYA, et al. ${ }^{40}, 2003$; LEE, et al. ${ }^{50}$, 1995), havendo um aumento da porosidade e rugosidade dessa estrutura (PIMENTA, et al. $^{66}$, 2003; RIEHL $\left.{ }^{70}, 2002 ;\right)$, as quais podem ser responsáveis pela diminuição da microdureza do esmalte (CAMILLI; PAMEIJER ${ }^{15}$, 2001; JUNQUEIRA, et al. ${ }^{44}, 2000$; TITLEY; TORNECK; SMITH ${ }^{80}$, 1988).

Outros autores, no entanto, afirmam que o uso dos agentes clareadores em altas concentrações não causam alterações na textura superficial do esmalte dentário, quando submetido ao tratamento com agentes clareadores, desde que supervisionados pelo dentista (GULTZ et al. ${ }^{26}$, 1999; SULIEMAN, et al. ${ }^{79}, 2004$; WORSCHECH, et al. $\left.{ }^{82}, 2003\right)$, porém tornam a superfície do esmalte mais susceptível, no processo de abrasão, às alterações de desgaste e rugosidade superficial (JOSEY, et al. ${ }^{43}$, 1996; KALILI et al. ${ }^{45}$, 1991; WORSCHECH, et al. ${ }^{82}$, 2003). 
Dessa maneira, é importante que os profissionais conheçam as técnicas clareadoras mais representativas para utilização sobre o esmalte dental, principalmente ao avaliar o desgaste e a rugosidade superficial, podem nortear que tratamentos seriam os mais inócuos e, conseqüentemente, mais indicados para se obter, além do efeito clareador, a máxima preservação da integridade dos tecidos duros dentais. 
2. REVISÃO DA LITERATURA 


\section{REVISÃO DA LITERATURA}

\subsection{Evolução do clareamento}

O interesse para a realização do clareamento dental remonta ao final do século XIX. Em 1850, DWINELLE ${ }^{18}$ publicou no "American Journal of Dental Science" diversos experimentos com dentes despolpados, os quais caracterizaram a introdução do processo de clareamento dental no meio odontológico. Nesse estudo, afirmou que a idéia de clarear dentes manchados lhe havia surgido naturalmente e que utilizou, para tanto, diversos compostos contendo o íon cloro, vapores de enxofre e alguns ácidos, como o oxálico; usou ainda o cloreto de cálcio e de sódio, formando uma pasta destes com o fosfato de cálcio. Sugeriu a hipótese de que o mecanismo de ação do cloro provavelmente seria o de atingir os pigmentos de ferro contidos nos tecidos dentários oriundos do sangue, com eles reagir e fazer com que estes saíssem pelas porosidades do dente; também supôs que o ácido oxálico agisse como um solvente do ferro. Sua conclusão foi a de que os íons de cloro seriam o melhor meio para se eliminar as manchas dos dentes.

KINGSBURY46, em 1861, publicou um artigo na revista "The Dental Cosmos", onde salientou a inquietação da comunidade odontológica com os manchamentos dentais mais conhecidos da época, os quais eram resultantes da aplicação de nitrato de prata, usado como dessensibilizante dentinário, ou da penetração de sangue nos túbulos dentinários nos casos de necrose pulpar. Ele descreveu suas tentativas em promover o clareamento de dentes manchados, pois valorizava a manutenção dos dentes naturais, ou da sua maior integridade possível, em detrimento da substituição por elementos artificiais. Assim, descreveu os diversos experimentos realizados, até encontrar uma substância que considerou efetiva para o propósito de induzir a "descoloração"; relatou o tratamento bem sucedido numa paciente jovem, que apresentou necrose pulpar em dois dentes antero-superiores nos quais, após a abertura da câmara pulpar, colocou um chumaço de algodão contendo tintura de iodo com o objetivo de "neutralizar o material necrótico"; após essa intervenção, aplicou cianeto de potássio, justificando que isto seria necessário não somente para 
remover as manchas provocadas pelo iodo, como para agir como um solvente da "hematina", o que seria o corante dos glóbulos vermelhos. Relatou que dissolveu dez grãos de cianeto de potássio em água, no momento de sua aplicação, formando uma solução que foi colocada na câmara pulpar, ali permanecendo por 5 a 10 minutos, depois foi lavada com água tépida para remoção total da solução. Verificou que esse procedimento era mais vantajoso do que os que usavam ácidos e outras substâncias, por produzir, na maioria dos casos, efeitos imediatos sem causar injúrias à dentina.

HARLAN $^{28}$ publicou, em 1884, suas bem sucedidas experiências, durante um período de 18 meses, para o clareamento de dentes despolpados. Era necessário o uso de isolamento absoluto, remoção de toda a dentina manchada da cavidade pulpar coronária e lavagem da mesma com água ou preferencialmente com peróxido de hidrogênio. O principal agente clareador utilizado era o cloreto de alumínio hidratado que, ao entrar em contato com a dentina seca recebia uma ou duas gotas de água, iniciando-se o processo de clareamento pela liberação do íon cloro. O autor esclareceu que os fluidos orais nunca deveriam entrar em contato com a cavidade pulpar e para tal, esta deveria estar hermeticamente selada.

Em 1889, KIRK ${ }^{47}$, descreveu os prováveis mecanismos químicos do clareamento dental. Relatou o seu método para o clareamento de dentes despolpados baseado na liberação de ácido sulfúrico, a partir de uma mistura de sulfito de sódio (100gramas) com ácido bórico (70 gramas). Uma pequena porção era colocada na câmara pulpar e adicionava-se uma gota de água, fechando-se imediatamente a cavidade com guta-percha. Os resultados foram gratificantes, ocorrendo o clareamento dental, segundo o autor, mais rapidamente do que quando se usava o cloro.

Em 1910, FISCHER ${ }^{20}$ apresentou uma técnica de clareamento dental utilizando o Peridrol, uma substância à base de peróxido de hidrogênio. Para o clareamento de dentes despolpados, a solução era utilizada a 30\%. Após instalação de dique de borracha, promovia-se a abertura coronária e a colocação de um 
chumaço de algodão embebido em peróxido de hidrogênio a 30\% na câmara pulpar. Uma gaze, também embebida com o peróxido, era colocada em toda a volta da coroa dental e os olhos do paciente eram protegidos com uma toalha. A gaze era exposta à luz solar por uma hora e meia na primeira sessão, e uma hora nas subseqüentes, com intervalo de três dias entre elas, num total de quatro a cinco sessões. O dente era restaurado provisoriamente, até a restauração definitiva feita com cimento de silicato. Para o clareamento de dentes polpados, utilizava o Peridrol a $15 \%$, seguindo o mesmo protocolo, obtendo bons resultados.

Escrevendo um artigo sobre a remoção de manchas em esmalte mosqueado, $\mathrm{AMES}^{2}$, em 1937, afirmou que as manchas desse tipo poderiam ser causadas pela ingestão de água e, provavelmente, por outros alimentos com excessiva quantidade de fluoretos, durante o período de calcificação dentária, as quais poderiam ser removidas pelo método por ele preconizado. Este consistia na obtenção de uma mistura de cinco partes de peróxido de hidrogênio a 100\%, com uma parte de éter, em volume; era realizado o isolamento absoluto do dente a ser tratado, uma vez que a solução levava a injúrias no tecido mole. Um chumaço de algodão embebido na solução deveria ser colocado sobre o dente, para então sofrer a ação clareadora de um instrumento aquecido, processo continuamente repetido por um tempo que variava de 30 minutos a 1 hora. $\mathrm{O}$ autor observou que, finalizado o tratamento, podia-se notar que as áreas não afetadas pelo manchamento estavam clareadas em demasia, sendo que essa pequena alteração voltava ao normal após duas ou três semanas. Como forma de controle, eram feitas fotografias antes e após o tratamento, com mais um controle após três semanas.

Com o objetivo de clarear dentes vitais manchados por tetraciclina, CHRISTENSEN $^{16}$, em 1978, descreveu a técnica operatória realizada em consultório. Era feito o isolamento absoluto do campo operatório e amarrias com fio dental em todos os dentes, protegendo assim os tecidos moles. Condicionado o esmalte com ácido fosfórico, na concentração de 40 á 50\%, por um minuto e aplicação do peróxido de hidrogênio á 35\% ativado pelo calor. Nos casos em que o tratamento não alcançava o resultado desejado e não solucionava as exigências do 
paciente, indicavam-se restaurações indiretas, como facetas ou coroas totais de resina ou porcelana, resolvendo assim, o problema estético do paciente.

Um grande impulso, no entanto, em relação aos tratamentos clareadores dentais ocorreu com a divulgação da técnica de HAYWOOD; HEYMANN ${ }^{32}$, em 1989, para clareamento de dentes vitalizados, na qual o paciente usava uma moldeira individual carregada com o produto clareador, durante o período noturno, enquanto dorme, processo que ficou amplamente conhecido como clareamento doméstico ou caseiro. Salientaram várias desvantagens do que se denominou de tratamento tradicional para dentes vitalizados, em consultório, feito à base de peróxido de hidrogênio como: o número excessivo de passos técnicos, a existência de efeitos colaterais, a necessidade de condicionamento ácido, o risco do uso de um peróxido tão concentrado que tornava necessária a proteção do paciente, o grande tempo clínico necessário para se conseguir resultados satisfatórios, o custo elevado e o alto índice de recidivas num intervalo de 2 a 3 anos. Afirmaram que o novo método oferece segurança e eficácia para dentes levemente descoloridos, citando como vantagens da técnica o fato de não ser necessário o condicionamento ácido, o menor tempo clínico, o menor custo para o paciente e a utilização de uma substância que não é cáustica, mas sendo de fundamental importância a supervisão do tratamento pelo dentista. A técnica consistia, primeiramente, no registro da cor dos dentes do paciente, com uma escala de cores padronizada ou mediante fotografias, para posterior comparação. Era feita a moldagem das arcadas com alginato e procedia-se à confecção de um modelo de gesso. Sobre este, era confeccionada em máquina a vácuo, uma moldeira plástica individual, para uso noturno Forneciam ao paciente um tubo de peróxido de carbamida a 10\%, instruíamno a colocar o gel clareador nos espaços adequados da moldeira e dormir com aquele dispositivo por, aproximadamente, 2 a 5 semanas. Observaram que alguns problemas ocorriam no início do tratamento, como suave irritação localizada na gengiva, leve sensibilidade a variações térmicas e pequeno desconforto por sensibilidade dentária exacerbada na primeira hora após a remoção da moldeira, os quais desapareceram na segunda semana de tratamento. Concluíram que esse novo tratamento clareador era conservador e deveria ser considerado como a 
primeira alternativa para se tratarem dentes levemente manchados, uma vez que apresenta como principal vantagem o pouco tempo de permanência no consultório, significando economia de tempo e dinheiro para o paciente. No entanto, deveriam ser realizadas mais pesquisas sobre ela.

Em uma revisão de literatura sobre a evolução do clareamento de dentes polpados, MONDELLI ${ }^{62}$, em 2003, descreve as técnicas de clareamento mais atuais, entre elas a caseira e a de consultório, com e sem a utilização de agentes fotossensíveis, bem como os materiais e os aparelhos de ativação por luz para o clareamento como, luz halógena, arco de plasma, luz híbrida (LED e Laser de Diodo), Laser de Argônio, laser de Diodo. O autor conclui que as várias opções para a realização do clareamento de dentes polpados, independente do tipo e do grau de alteração de cor que apresentem, permitem ao profissional a escolha da técnica, dos materiais e dos aparelhos ativadores que melhor se enquadrem nas características individuais dos pacientes e na realidade do dia-a-dia do consultório. Existem várias opções de equipamentos para serem utilizados no clareamento de consultório ou para outras aplicações clínicas, as quais apresentam custos variados. Os resultados estéticos alcançados se apresentam altamente satisfatórios, despendendo tempo curto para o tratamento e tornando-se a tônica do século em termos de tratamentos cosméticos e estéticos.

\subsection{Clareamento Utilizando Agentes Fotossensíveis}

De acordo com $\mathrm{KUTSCH}^{48}$, em 1993, desde o desenvolvimento do laser em 1962, existem inúmeros estudos para seu uso na odontologia, e pesquisas têm examinado o efeito do mesmo nos tecidos duros. A energia do laser de $\mathrm{CO}_{2}$, com comprimento de onda de 10.600nm, é absorvido pela água, gerando muito calor, o que leva à carbonização do tecido. O laser Nd:YAG, com comprimento de onda de 1.064nm, não é bem absorvido pela água, mas é particularmente absorvido pela hemoglobina e melanina. A luz do Laser de Argônio, com dois comprimentos de onda de 488 e 514,5nm é pobremente absorvida pela água, mas é bem absorvida pela hemoglobina, melanina e tecidos de coloração escura e pode polimerizar 
resinas compostas. O autor conclui que os lasers possuem diferentes comprimentos de onda, que resultam em diferentes profundidades de penetração, sendo absorvidos variavelmente, gerando calor em tecidos distintos.

LORENZO et al. ${ }^{53}$, em 1996, apresentaram um estudo clínico utilizando um agente clareador, composto por peróxido de hidrogênio a 35\%, misturado a um pó constituído por diversas substâncias, entre elas persulfinato de potássio, sulfato de manganês monoidratado, sulfato de ferro, sílica amorfa hidratada, polimetil éter maleato de potássio e corante verde-guiné e ativado por luz halógena, o sistema Hi Lite Dual (Shofu Dental Corporation, USA). Dessa mistura resultava um gel indicado para clareamento de dentes vitalizados e desvitalizados, aplicado em consultório, sob isolamento absoluto e após condicionamento com ácido fosfórico a 37\% por 15 segundos. O gel era ativado com luz halógena por 4 minutos e mantido em contato com os tecidos dentais por 5 minutos, para que a ação química se completasse, podendo ser realizada até três aplicações na mesma sessão. Os autores chamaram atenção para não se deixar o HiLite como curativo de demora, com o intuito de prevenir qualquer efeito indesejável, como reabsorção cervical externa, salientando a necessidade de mais estudos a respeito da estabilidade de cor e de possíveis efeitos adversos que pudessem ocorrer, tanto nos dentes quanto nos tecidos periodontais.

Em 1997, GOLDSTEIN ${ }^{24}$ publicou um artigo de revisão de literatura sobre o clareamento de consultório com peróxido de hidrogênio em alta concentração, descrevendo o histórico, a técnica e especulando o futuro do mesmo. Considerou esse tipo de clareamento como uma opção segura, eficaz e rápida, porém relatou que os profissionais preferem o clareamento caseiro. A técnica consiste de isolamento com dique de borracha dos dentes a serem clareados, aplicação de gases saturadas em peróxido de hidrogênio sobre as estruturas dentárias, por 20 a 30 minutos, em duas a três aplicações, podendo ter sua reação acelerada com a utilização de uma fonte de calor, conseguida através de uma lâmpada halógena convencional, até a luz laser. O autor espera que a comunidade odontológica entenda as vantagens e riscos da técnica, atendendo às necessidades estéticas dos 
pacientes e declara que o uso da técnica caseira, simultaneamente com a de consultório, tem a possibilidade de acelerar o processo clareador, obtendo o efeito clareador em menor tempo.

Em 1997, GABER ${ }^{22}$ relata o uso do peróxido de hidrogênio catalisado com os laseres de argônio e $\mathrm{CO}_{2}$, ou uma combinação dos dois. Quando a energia laser é emitida para o substrato, a mesma é transmitida, refletida ou absorvida, porém é mais eficiente quando absorvida. Acredita-se que a pigmentação escura do dente pode realmente absorver a energia do Laser de Argônio, excitando as moléculas para potencializar o processo de clareamento. Os radicais livres de oxigênio liberados no processo quebram a dupla valência da união em cadeias mais simples e menos pigmentada. A sugestão do uso adicional do laser de $\mathrm{CO}_{2}$ é a partir do momento em que o dente torna-se mais branco, pois o tecido vai perdendo a pigmentação e a absorção da energia do laser de argônio começa a ser menos efetiva. A energia do laser de $\mathrm{CO}_{2}$, emitida na forma de calor, é absorvida pelas substâncias que contêm água, sendo então, mais efetiva. A rápida absorção da energia laser aquece a solução mais rapidamente que o sistema de aquecimento (calor) "convencional". Ainda existem poucas pesquisas para comprovar que este método seja melhor que o sistema convencional de clareamento. O fato é que o agente clareador fotosenssível, peróxido de hidrogênio, e o laser sozinhos não clareiam o dente, sendo o laser utilizado apenas para catalisar a reação pelo aumento da temperatura.

Segundo a $\mathrm{ADA}^{1}$, em 1998, os dados disponíveis sobre as técnicas de clareamento utilizando os lesers provêm dos fabricantes, que citam o uso de produtos clareadores anteriormente aprovados, os quais utilizam fontes de calor ou lâmpadas para acelerar o processo de clareamento. O laser é utilizado para melhorar a ativação do agente clareador. De acordo com os fabricantes, a energia do laser é totalmente absorvida pelo gel clareador, resultando em um clareamento superior, sem efeitos colaterais, e realizado em apenas uma sessão de atendimento. Cada fabricante determina qual o tempo e o comprimento de onda que, cada aparelho deve utilizar para este procedimento. Devido á preocupações e falta de 
conhecimento sobre as interações do laser com os tecidos duros e a falta de estudos clínicos controlados, o clareamento dental auxiliado pelo laser de $\mathrm{CO}_{2}$ ainda não pode ser recomendado. Baseado nos usos previamente aceitos, o uso do laser de argônio no lugar de luz halógena pode ser aceitável, se os procedimentos forem rigorosamente obedecidos.

REYTO ${ }^{69}$, em 1998, através de uma revisão de literatura, afirmou que o efeito clareador com o uso do laser é obtido por um processo químico de oxidação. Quando a energia laser é aplicada, $\mathrm{O}_{2} \mathrm{O}_{2}$ quebra-se em água e radicais livres de oxigênio, o qual combina-se e remove as moléculas escuras. Embora algumas experiências tenham sido feitas algum tempo antes, o clareamento com laser começou oficialmente em fevereiro de 1996 com a aprovação do íon Lase Technology (ILT), para os Lasers de Argônio e $\mathrm{CO}_{2}$ associados com agentes químicos. A energia do laser de argônio, na forma de luz azul, com o comprimento de onda entre 480 e 514nm, na parte visível do espectro, é absorvida pelas cores escuras. Já o Laser de $\mathrm{CO}_{2}$ tem sua energia emitida na forma de calor, no espectro invisível com comprimento de onda de 10.600nm. Essa energia do Laser de $\mathrm{CO}_{2}$ pode aumentar o efeito do clareamento, após o processo inicial pelo Laser de Argônio. Após a limpeza e isolamento, para proteção dos tecidos moles, o agente clareador é colocado na superfície dos dentes e o Laser de Argônio (ACCUCURE 3000) é ativado por 30 segundos em cada dente. O agente é removido por um sugador e o processo é repetido algumas vezes. Para acelerar a reação de clareamento, o Laser de $\mathrm{CO}_{2}$ é utilizado em temperatura controlada. Durante o clareamento a laser, o maior problema parece estar associado à inexperiência com a técnica e as regras devem ser rigorosamente seguidas para se obter o efeito e a segurança desejados.

Em 2000, GIOIA ${ }^{23}$ avaliou a efetividade de quatro técnicas clareadoras para dentes despolpados. Foi realizada a abertura da câmara pulpar de incisivos bovinos, os quais foram armazenados em soro fisiológico e posteriormente imersos em sangue durante 18 dias, para que ocorresse o manchamento dos dentes. No grupo I foi utilizado o agente clareador Hi-Lite ativado por luz halógena. O clareador foi 
colocado no interior da câmara pulpar e na face vestibular, sendo ativado com a lâmpada halógena por 3 min em cada face, com duas aplicações na mesma sessão. O grupo II foi clareado com peróxido de hidrogênio ativado por laser de Argônio, o gel foi ativado por 2 min em cada face, removido e reaplicado. O procedimento foi repetido oito vezes na mesma sessão, seguindo os seguintes parâmetros para o laser de argônio: comprimento de onda de 514nm, diâmetro do feixe de $1 \mathrm{~cm}$, potência de $600 \mathrm{~mW}$ e intensidade de $750 \mathrm{~mW} / \mathrm{cm}^{2}$. No grupo III foi empregado o peróxido de hidrogênio ativado por espátula aquecida, o gel foi depositado nas faces lingual e vestibular, e uma espátula aquecida em lamparina foi colocada sobre as mesmas, realizando 3 sessões de 30 min cada. No grupo IV foi realizado o "Walking Bleaching", selando na câmara pulpar uma mistura de perborato de sódio e peróxido de hidrogênio, durante 3 dias, com três trocas, totalizando 9 dias de tratamento . Os resultados mostraram que as quatro técnicas foram capazes de promover o efeito clareador de maneira satisfatória, no entanto houve diferença significativa em relação à tonalidade de cor. Os grupos tratados com peróxido de hidrogênio e ativados com laser de argônio e o "Walking Bleaching" apresentaram resultados estéticos superiores em relação aos demais grupos.

ZANIN, et al. ${ }^{84}$, em 2003, descreveram o mecanismo de ativação do gel clareador, a utilização dos lasers e LED's no clareamento, a importância do diagnóstico e técnica de clareamento dental em uma única sessão com equipamento que associa laser e LED's simultaneamente. Os autores afirmam que as técnicas de clareamento dental evoluíram para facilitar sua utilização, assim o tempo de contato do produto com o dente, que com o clareamento caseiro é de uma semana a 15 dias, passa a ser feito em pouco mais de uma hora. Isso devido à potencialização do gel clareador peróxido de hidrogênio a 35\% que ao ser ativado por emissões fotônicas, não ionizantes e concentradas, como os lasers e LED, interagem com os tecidos produzindo efeitos fotoquímicos e mínimos efeitos fototérmicos, pois tem como alvo moléculas escurecidas, gerando mínimo aumento de temperatura, uma vez que aquecem o produto e não a estrutura dental. Nessa técnica, o gel é aplicado na estrutura dentária e ativado por 30 segundos, permanecendo por 5 minutos para que pudesse agir, por ação química, podendo ser reaplicado de 4 a 6 vezes. 
Concluíram que as vantagens do clareamento realizado em única sessão é melhorar o conforto, a segurança e diminuir o tempo de tratamento.

\subsection{Mecanismo de Ação dos Agentes Clareadores}

Possivelmente pela primeira vez, em 1889, $\mathrm{KIRK}^{47}$, descreveu os prováveis mecanismos químicos do clareamento dental, afirmando que o sucesso do clareamento dental está na destruição dos pigmentos que afetam as estruturas dentais, por um agente químico suficientemente capaz para esse propósito. Classificou as substâncias clareadas em duas classes: as oxidantes e as redutoras, onde as primeiras destruíam pigmentos pela remoção de hidrogênio, e as segundas o fariam pela remoção do oxigênio. Dentre as substâncias oxidantes, citou o peróxido de hidrogênio, o cloro e o permanganato de potássio reduzido pelo ácido oxálico, pois se assim não o fosse, seu produto final seria marrom e acabaria manchando os tecidos dentários.

Com o propósito de determinar a influência da temperatura na condutância hidráulica da dentina com e sem a "smear layer", PASHLEY; THOMPSON; STEWART ${ }^{65}$, em 1983, realizaram um estudo in vitro. Discos de dentina de dente humano foram preparados e tiveram a permeabilidade dentinária avaliada nas temperaturas de $10^{\circ}, 20^{\circ}, 30^{\circ}, 40^{\circ}$ e $50^{\circ} \mathrm{C}$, em dentina condicionada com ácido cítrico á $6 \%$, para remoção da "smear layer" e em dentina com a manutenção da "smear layer". Os resultados demonstraram que um aumento de temperatura de $10^{\circ}$ para $50^{\circ} \mathrm{C}$ provocou um aumento na condução hidráulica pela dentina de $179 \%$ em presença da "smear layer" e de 406\% quando esta era removida. Relataram que este aumento na permeabilidade dentinária, ocorrido em função do aumento de temperatura, está relacionado a um discreto aumento do diâmetro dos túbulos dentinários, em função do coeficiente de expansão linear da dentina e da alteração na viscosidade do fluído. Segundo os autores um aumento de temperatura em $10^{\circ} \mathrm{C}$, dobra a velocidade da reação química. 
BOWLES; UGWUNERI ${ }^{11}$, em 1987, observaram in vitro, que os tecidos dentários são permeáveis ao peróxido de hidrogênio e que essa permeabilidade aumenta com a aplicação de calor. Esses resultados foram obtidos pela exposição da face vestibular de incisivos centrais superiores ao peróxido de hidrogênio a concentrações de 1,10 e $30 \%$ a $37^{\circ} \mathrm{C}$ por 15 minutos. Ainda nesse trabalho, os autores expuseram 24 dentes ao peróxido de hidrogênio a 10\%, sendo um grupo a temperatura de $37^{\circ} \mathrm{C}$ e outro de $50^{\circ} \mathrm{C}$. A câmara pulpar desses dentes foi preenchida com solução tampão de acetato, a qual serviu como marcador da presença do peróxido de hidrogênio. Na análise dos resultados, ficou evidente que a maior difusão dessas substâncias ocorre em função da concentração apresentada pela solução e pelo aumento de temperatura. Os autores comentam que, apesar de haver a penetração do peróxido de hidrogênio, os níveis alcançados são baixos quando comparados àqueles produzidos pelas enzimas pulpares. Esse fato explicaria a razão pela qual os danos pulpares são notavelmente baixos com o uso clínico dessa substância.

McEVOY ${ }^{56}$, em 1989, teceu considerações sobre o mecanismo de ação do peróxido de hidrogênio e do ácido hidroclorídrico para remoção de manchas associadas a fluorose, injúrias pulpares e tetraciclina. O ácido hidroclorídrico não é considerado um agente ideal para remoção de manchas, por causa do seu mecanismo de ação. O ácido utilizado apenas com abrasivos ou associados ao calor, como era a princípio utilizado, provoca a desmineralização do esmalte, não sendo seletivo na remoção das manchas. Dessa forma tem indicação limitada, sendo utilizado apenas para remoção de manchas superficiais no esmalte. Já o peróxido de hidrogênio é mais seletivo no seu mecanismo de ação, quando comparado ao ácido hidroclorídrico, pois não conta com a desmineralização para realizar a remoção das manchas. No entanto, o seu mecanismo de ação é difícil de ser descrito devido ao pouco conhecimento a respeito do assunto. Esse processo ocorre no esmalte e na dentina, provavelmente através de um mecanismo de oxidação dos pigmentos, causado pelo oxigênio liberado, que então efetua uma limpeza mecânica. O autor afirma que o esmalte é bastante permeável ao peróxido de hidrogênio devido ao baixo peso molecular deste e em função da sua habilidade 
em desnaturar proteínas, acontecendo assim um grande movimento iônico através dos tecidos dentários. Pode-se ainda associar o calor, para maior rapidez e eficácia da reação, apesar de existirem controvérsias sobre tal aspecto, especialmente no que diz respeito tanto ao tempo quanto à temperatura empregados, como aos efeitos deletérios causados nos tecidos pulpares.

ROTSTEIN; TOREK; LEWINSTEIN ${ }^{72}$, em 1991, examinaram o efeito do tempo e da temperatura do clareamento, na penetração do peróxido de hidrogênio a $30 \%$ durante o clareamento endogeno. Foram utilizados pré-molares humanos, os quais receberam tratamento endodôntico. Os dentes foram clareados com peróxido de hidrogênio a 30\%, pelos períodos de 5, 20, 40 e 60 minutos à temperaturas de $24^{\circ} \mathrm{C}, 37^{\circ} \mathrm{C}$ e $47^{\circ} \mathrm{C}$. Os resultados demonstraram que, não houve penetração significante do $\mathrm{H}_{2} \mathrm{O}_{2}$ após 5 min em nenhuma das temperaturas testadas, porém prolongando o tempo, houve penetração significante do $\mathrm{H}_{2} \mathrm{O}_{2}$ em cada uma das temperaturas, não havendo muita diferença entre as temperaturas de $37^{\circ} \mathrm{C}$ e $47^{\circ} \mathrm{C}$. Os autores concluíram que o aumento da temperatura do agente clareador é proporcional a penetração do mesmo no dente e sugere que se diminua o tempo e a temperatura, quando o peróxido de hidrogênio a 30\% for utilizado como agente oxidante.

HANKS et al. ${ }^{27}$, em 1993 relataram que o clareamento dental só é possível, graças à permeabilidade da estrutura dental aos agentes clareadores, que têm a capacidade de se difundir livremente, através do esmalte e da dentina e atuar na parte orgânica dessas estruturas, promovendo o clareamento. Segundo os autores a citotoxicidade do peróxido de hidrogênio é influenciada pela concentração do gel e pelo tempo de exposição sobre as estruturas dentárias.

CHEN; XU; SHING ${ }^{14}$, em 1993, determinaram a taxa de decomposição do peróxido de hidrogênio, frente a várias condições pela verificação do número de moléculas de oxigênio liberadas, tanto em soluções ácidas como básicas, inclusive analisando o efeito do calor e de íons metálicos. Os autores discorreram sobre a química dos peróxidos, chamando a atenção para aspectos químicos da respectiva 
reação de clareamento; usaram peróxido de hidrogênio a 30\% isoladamente, ou misturado com ácido hidroclorídrico a 36\% e éter anestésico, ou com hidróxido de sódio a $20 \%$, ou ainda com cloreto de ferro III, nas temperaturas de $16^{\circ}, 20^{\circ} \mathrm{C}$ e $45^{\circ} \mathrm{C}$. Afirmaram que tais misturas teriam provocado uma decomposição do peróxido em água e oxigênio. Suas conclusões, que denominaram como preliminares, resumidamente informam que a decomposição do peróxido de hidrogênio: 1) em geral havia sido acelerada pelo calor; 2) fora rápida e mais violenta na solução de hidróxido de sódio, do que aquelas observadas nas soluções com ácido hidroclorídrico e com éter em baixa temperatura $\left(16^{\circ}\right.$ e $\left.20^{\circ} \mathrm{C}\right)$; 3) havia sido violenta quando da mistura com cloreto de ferro III pulverizado, ocasião em que a solução foi contaminada com partículas marrons, que poderiam vir a manchar os dentes; e 4) necessitava de posteriores estudos em relação ao proporcionamento tradicionalmente usado nas soluções com ácido hidroclorídrico, éter e peróxido de hidrogênio. Os autores concluíram que a reação de decomposição do peróxido de hidrogênio pode ser acelerada sem o uso do calor, mas misturando-o ao hidróxido de sódio minimizando os efeitos causados pelo calor ao órgão dental. Ressaltam que o peróxido de hidrogênio é mais estável em solução ácida que em solução básica.

Segundo LYNCH et al. ${ }^{52}$, em 1995, os agentes clareadores são, geralmente, à base de peróxido, que pode produzir radicais livres altamente reativos. Esses radicais livres derivados do oxigênio degradam a molécula cromatogênica orgânica em moléculas menores, e menos pigmentadas, via processo oxidativo, ou ocasionalmente por redução. O processo de clareamento de manchas provocadas por substâncias inorgânicas ainda não está totalmente estabelecido. O peróxido de hidrogênio produz radicais hidroxila pela luz, calor ou por irradiação.

Lançando algumas hipóteses sobre o que possivelmente ocorre quando os peróxidos de hidrogênio ou de carbamida atuam sobre as estruturas dentais, RIEHL $^{70}$, em 2002, supõe o provável mecanismo de ação para as condições de clareamento mais popularizadas atualmente, que são os denominados tratamentos clareadores "de consultório" e "caseiro". 
CLAREAMENTO DE CONSULTÓRIO: realizado com solução de peróxido de hidrogênio a 30-35\%, sendo ativado de acordo com o sistema clareador empregado, por calor ou por radiação luminosa (incluindo a radiação proveniente dos aparelhos de LASER). Uma vez decomposto em água e oxigênio nascente, este último penetra rapidamente através dos poros do esmalte, trafegando através da matriz orgânica do esmalte e da dentina. O oxigênio nascente reage prontamente com os pigmentos, fazendo com que as fracas ligações entre as moléculas cromatógenas e a matriz orgânica sejam rompidas, as moléculas continuam a ser oxidadas pelos íons de oxigênio nascente, tornando-se menores, menos complexas e incolores. Dependendo do tempo de contato e da concentração do agente clareador, a efervescência da reação de clareamento acabaria, por arrasto, expulsando o remanescente molecular do pigmento, total ou parcialmente oxidado, para fora da estrutura dentária.

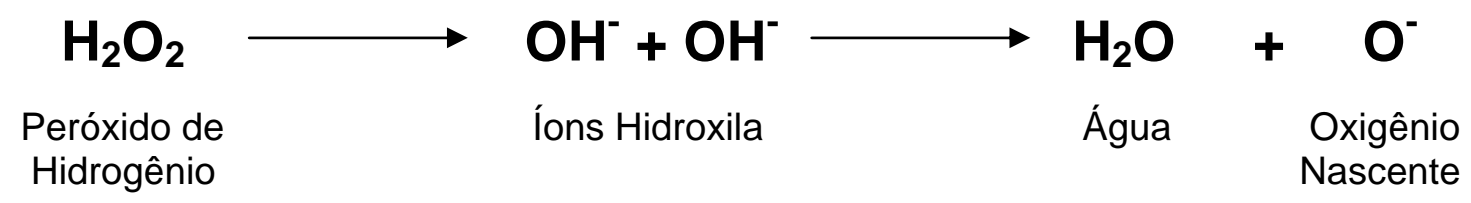

CLAREAMENTO CASEIRO: utiliza o peróxido de carbamida sob a forma de um gel ou solução colocado com o auxílio de uma moldeira; seu pH neste momento gira em torno de 6.5 (nesse pH ligeiramente ácido, o peróxido é mais estável e se conserva por mais tempo), mas rapidamente se eleva para um pico de aproximadamente 9.8 (LEONARD; BENTLEY; HAYWOOD ${ }^{51}$, 1994). Isso favorece a decomposição de outras moléculas de peróxido, o que ocorreria em cadeia, já que um $\mathrm{pH}$ alcalino o desestabiliza ionicamente. Dessa forma, o peróxido de carbamida decompõe-se em peróxido de hidrogênio e uréia (responsável pela alcalinidade). Para iniciar a decomposição do peróxido de carbamida, provavelmente o pontogatilho sejam as enzimas presentes na saliva. 


\section{$\mathrm{NH}_{4}+\mathrm{CO}_{2}$}

Amônia Gás Carbônico

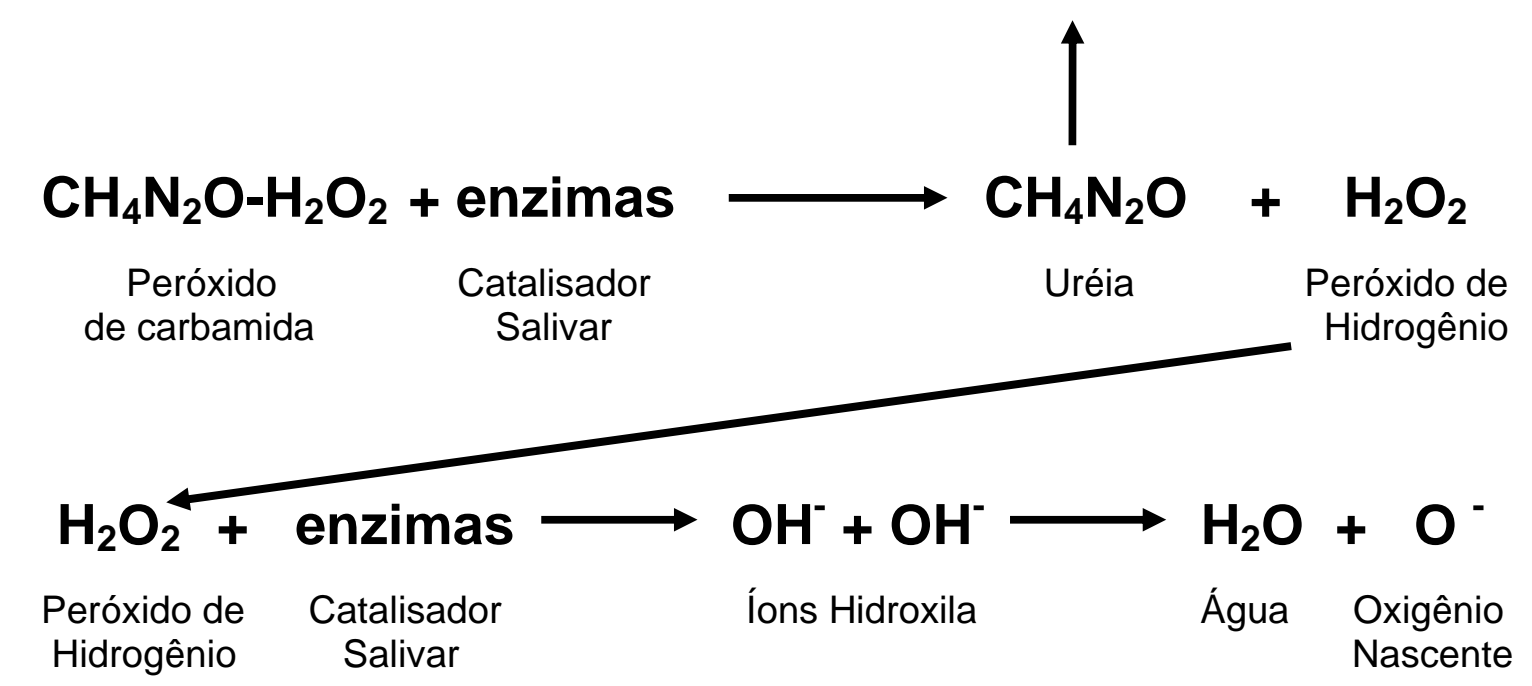

\subsection{Alterações Morfológicas no Esmalte após Clareamento}

Foi avaliado por TITLEY; TORNECK; SMITH ${ }^{80}$, em 1988, o efeito da solução de peróxido de hidrogênio a 35\% sobre a superfície morfológica do dente humano. Fragmentos de esmalte foram divididos em dois grupos, um experimental e um controle. O grupo experimental recebeu tratamento com peróxido de hidrogênio a $35 \%$, por tempos que variavam de 1 a 60 minutos, alguns espécimes deste grupo foram pré-tratadas com ácido fosfórico a 37\% por 60 segundos e outros foram póstratadas com ácido fosfórico por 60 segundos. O grupo controle recebeu o mesmo tratamento com ácido fosfórico a 37\%, mas em vez do tratamento clareador, foi mantido em solução salina pelo mesmo período de tempo. Os autores observaram, por meio de microscopia eletrônica de varredura, que no grupo controle, quando comparado ao experimental, a exposição ao peróxido de hidrogênio induziu a presença de um "precipitado branco", conferindo à superfície do esmalte uma aparência de "congelado", como se houvesse partículas de gelo aderidas à sua superfície. A associação do pré ou do pós-tratamento com ácido fosfórico a 37\%, acima descrito, resultou na presença mais evidente do precipitado e no aumento da porosidade da superfície do esmalte. 
HAYWOOD, et al. ${ }^{33}$, em 1990, utilizando a microscopia eletrônica de varredura, verificaram o efeito do peróxido de carbamida a $10 \%$ na superfície de esmalte humano. A coroa desses dentes foi dividida ao meio e a metade mesial serviu de controle, sendo selada, para não ter contato com o agente clareador. A outra metade foi exposta ao gel clareador por 7 horas, com a manutenção de 100\% de umidade e temperatura de $37^{\circ} \mathrm{C}$. Depois, o gel clareador foi removido e o dente imerso em saliva artificial por 1 hora, perfazendo um total de 245 horas em contado com o peróxido de carbamida e 34 horas de imersão em saliva artificial, o que equivale a aproximadamente 5 semanas de clareamento caseiro. Dentes não tratados e condicionados com ácido fosfórico a 37\% foram preparados visando à comparação com os outros grupos. As fotomicrografias revelaram não haver diferença entre as superfícies tratadas ou não com peróxido de carbamida, diferenciando-se, entretanto, em relação ao grupo tratado com ácido fosfórico a $37 \%$. Todos os dentes foram clareados porém, não houve diferença de cor entre a face controle e a exposta ao clareador, indicando a alta difusibilidade do peróxido de carbamida pela dentina. Também não houve diferença na textura entre a área tratada e não tratada.

HUNSAKER; CHRISTENSEN; CHRISTENSEN ${ }^{41}$, em 1990, observaram o efeito de 7 agentes clareadores em dentina com smear layer, esmalte íntegro e materiais restauradores (liga de ouro, amálgama, porcelana, resina de micro e macropartícula). Os agentes clareadores escolhidos variaram na concentração do peróxido de carbamida ou peróxido de hidrogênio e no pH. Cada amostra de material, dentina e esmalte foi imersa nas substâncias testadas por 2-3 horas diárias durante 5 semanas. Após o período de 2 e 5 semanas, todas as amostras foram observadas pela microscopia eletrônica de varredura, que evidenciou no esmalte, pouca ou nenhuma mudança; na dentina, remoção de smear layer; liga de ouro, amálgama e resina de micropartículas, nenhuma mudança; na porcelana, suave mudança; na resina de macropartícula, ligeiro aumento na rugosidade. Os autores concluíram que os agentes clareadores utilizados não provocaram alterações significativas na estrutura dentária e de materiais restauradores e, que os agentes clareadores são eficientes clinicamente. 
COVINGTON et al. ${ }^{17}$, em 1990, pesquisaram alterações superficiais no esmalte clareado com peróxido de carbamida de uso caseiro, através da microscopia eletrônica de varredura e espectrocopia eletrônica para análise química (ESCA), buscando alterações topográficas ou mudanças químicas na estrutura do esmalte humano. A superfície mesial dos dentes foi tratado por 4 horas diárias, durante 3 semanas, e a distal permaneceu como controle. Detectaram na MEV suaves alterações, semelhantes a erosões na superfície do esmalte, e na ESCA encontraram perda de componentes orgânicos nas superfícies clareadas. Concluíram que o gel de peróxido de carbamida pode estar associado com inflamação crônica, hipersensibilidade dentária e lesões pré-cancerígenas, sendo sugerido um controle no processo de oxidação, no qual a parte orgânica do esmalte é mobilizada sem produzir topografias extremamente inaceitáveis na superfície do esmalte.

Em 1991, HAYWOOD; HOUCK; HEYMANN ${ }^{34}$ não encontraram alterações morfológicas na superfície do esmalte humano, analisado em microscopia eletrônica de varredura, quando este foi exposto a quatro produtos clareadores, com diferentes $\mathrm{pH}$. O grupo I foi tratado com Proxigel, produto de baixo $\mathrm{pH}$ e liberação lenta de oxigênio. O grupo II, com Gly-Oxide, com elevado $\mathrm{pH}$ e rápida liberação de oxigênio. No grupo III, foi usado o White \& Brite com alto pH e liberação moderada de oxigênio. Todos esses produtos são à base de peróxido de carbamida a 10\%. No último grupo, aplicou-se o Peroxil, um gel à base de peróxido de hidrogênio a 1,5\%, possuindo baixo $\mathrm{pH}$. Os dentes foram divididos ao meio no sentido gengivo-incisal, onde uma parte foi clareada durante um total de 250 horas, e a outra metade foi imersa em água destilada pelo mesmo tempo. Permanecendo por mais 20 horas em água destilada. Esses espécimes foram comparados com o grupo controle, onde nenhum tratamento foi aplicado e, com o grupo condicionado com ácido fosfórico a 37\%. Nesse trabalho, as superfícies de todos os grupos diferiram significantemente apenas quando comparado com o grupo condicionado com ácido fosfórico, não ocorrendo nenhuma modificação na textura dos espécimes clareados quando comparados com o controle. Os autores comentam que os produtos com baixo $\mathrm{pH}$ 
não causam desmineralização do esmalte, pois a solução de peróxido é instável e, quando em contato com a saliva ou tecido, rapidamente se dissocia.

Em uma investigação sobre os efeitos de três agentes clareadores à base de peróxido de carbamida a 10\%, na abrasão e resistência adesiva, KALLILI et al. ${ }^{45}$, em 1991, selecionaram 60 dentes recém-extraídos e os clarearam com três diferentes agentes clareadores durante 6 horas. Expuseram os dentes a 2.100 ciclos de escovação, utilizando escovas macias. Os dentes foram examinados em um metalográfico, que mensura a quantidade de esmalte removido. Concluíram que os três agentes clareadores aumentam a suscetibilidade à abrasão do esmalte quando submetido ao processo de escovação, quando comparado com o controle que não sofreu clareamento, porém não houve diferença estatística entre os agentes clareadores utilizados. Não encontraram diferença estatística na resistência adesiva com nenhum dos agentes clareadores testados.

BITTER $^{10}$, em 1992, comparou o efeito químico de três agentes clareadores, sobre a superfície do esmalte, por intermédio da microscopia eletrônica de varredura. Metade do esmalte do dente recém-extraído foi protegido, e a outra metade recebeu o tratamento clareador por 30 horas. Foram observadas alterações significantes na superfície do esmalte exposto aos agentes clareadores à base de peróxido de carbamida a 10\%. No grupo em que o agente clareador preconiza um pré-tratamento com uma solução que contêm ácido cítrico, ácido fosfórico poliéter e glicerina observaram, além do aumento da porosidade, áreas de dissolução superficial do esmalte. Nos demais grupos foram observadas alterações não uniforme na superfície do esmalte e porosidade evidente. O autor conclui que os agentes clareadores ou as soluções de pré-tratamento são naturalmente ácidas e possuem um efeito potencial de desmineralização, salientando, ainda, que a adição do efeito da escovação em conjunção com o efeito dos agentes clareadores deve ser considerado.

Em 1992, HAYWOOD ${ }^{35}$ estudou, através de uma revisão de literatura, o emprego do peróxido de hidrogênio nas três técnicas de clareamento 
profissionalmente executadas, abordando aspectos históricos, assim como as técnicas propriamente ditas; fez comentários sobre a segurança dos métodos ao longo do tempo, subdividindo-a em segurança absoluta e relativa para os clareamentos não-vital, vital em consultório, caseiro e produtos vendidos sem prescrição. Discutiu as vantagens e desvantagens das diferentes opções de clareamento, algumas indicações específicas e situações em que se deveria fazer a combinação das várias técnicas.

McGUCKIN; BABIN; MAYER ${ }^{57}$, em 1992, publicaram um trabalho onde foi analisada a possível alteração na morfologia do esmalte, sob a luz da microscopia eletrônica de varredura e da perfilometria, com o uso de três diferentes agentes clareadores durante 30 dias. Foram seguidos três protocolos de clareamento, dois caseiros e um de consultório: I) peróxido de carbamida a 10\%, com carbopol em pH 4,7, durante 8 horas diárias; II) peróxido de carbamida á 10\%, sem carbopol, em pH de 6,2, 24 horas ao dia, com intervalo de 3 minutos para aplicação de flúor gel 4\%; III) peróxido de hidrogênio 30\%, com pH 3,0, em quatro aplicações de $30 \mathrm{~min}$, com intervalo de 7 dias entre elas e ativação com luz halógena, único produto aplicado após condicionamento ácido do esmalte com ácido fosfórico a 37\% por 20s. Os resultados evidenciaram uma tendência ao alisamento do esmalte após a aplicação dos produtos de uso caseiro, os resultados do grupo que empregou peróxido de hidrogênio a 30\% precedido de condicionamento ácido apresentaram imagens sugestivas e concordantes com o aspecto do referido condicionamento. O aumento da porosidade, neste último grupo experimental, tanto pode ser devido à ação do ácido, que foi aplicado previamente ao agente clareador, quanto do baixo $\mathrm{pH}$ do agente clareador, ou ainda a uma interação dos dois produtos. Os autores concluem que as alterações superficiais no esmalte são evidentes nas três técnicas de clareamento e que a diferença entre as técnicas caseiras e a de consultório está relacionada ao $\mathrm{pH}$ dos agentes clareadores.

Em 1993, SHANNON et al. ${ }^{76}$ avaliaram os possíveis efeitos de três agentes clareadores à base de peróxido de carbamida a 10\%, com diferentes pH, sobre a microdureza e alteração morfológica superficial do esmalte, combinando uma 
metodologia in vivo e in vitro. Pequenos fragmentos de esmalte previamente autoclavados foram fixados a um dispositivo de acrílico removível, parecido com uma placa de Hawley, e posicionados na boca de pacientes, simulando condições próximas às que ocorrem num tratamento clareador in vivo. Os fragmentos foram clareados com um dos agentes clareadores selecionados ou permaneceram em saliva artificial (controle) por 15 horas diárias, fora da cavidade bucal, e permanecendo 8 horas na cavidade oral, durante quatro semanas. Não foram verificadas alterações significativas na microdureza do esmalte com nenhum dos tratamentos e o grupo controle. A microscopia eletrônica de varredura revelou alterações topográficas na superfície do esmalte com os três tratamentos clareadores empregados, os quais se caracterizam por um padrão irregular e tênue, com pequenas áreas de destruição superficial, sendo estas mais severas nos materiais que possuem um menor $\mathrm{pH}$. Concluíram que o clareamento com peróxido de carbamida a $10 \%$ altera o processo de remineralização do esmalte, quando este é exposto à saliva.

Em 1994, LEONARD JUNIOR; BENTLEY; HAYWOOD ${ }^{51}$ estudaram in vivo, as mudanças do $\mathrm{pH}$ salivar, em procedimentos de clareamento caseiro com peróxido de carbamida a 10\%, uma vez que a desmineralização do esmalte pode ocorrer num $\mathrm{pH}$ entre 5,2 a 5,8, e alguns agentes clareadores possuem pH ácido (entre 4,8 e $5,2)$, o qual poderia aumentar o risco de cárie pela desmineralização do esmalte. Tiveram a colaboração de quatro adultos, cujas arcadas superiores foram moldadas para confecção de moldeira individual, que recebia o agente clareador, cujo pH era de 5.3. No decorrer de vinte sessões de clareamento, onde em cada uma delas era medido o pH salivar entre as $13 \mathrm{~h}$ e $30 \mathrm{~min}$ e $17: 00 \mathrm{~h}$, os colaboradores foram orientados a não comer, beber ou fumar, duas horas antes de cada mensuração. $A$ saliva era coletada em frascos e analisada, usando como controle aquela colhida antes da primeira instalação da moldeira, nas condições de salivação estimulada ou não. Em seus resultados, não encontraram diferenças entre os dois modos de salivação, mas observaram significante queda do $\mathrm{pH}$ nos primeiros 15 minutos após a remoção do agente clareador. Puderem notar que, aos dez minutos, essa diferença deixou de existir e que o valor do $\mathrm{pH}$ aumentou até o final do experimento. 
Concluíram que a acidez do agente clareador à base de peróxido de carbamida a $10 \%$ é rapidamente neutralizada, não levando a uma desmineralização da estrutura dentária, pois os produtos resultantes da decomposição desse peróxido (principalmente a uréia) tendem a elevar o $\mathrm{pH}$ salivar.

BEM-AMAR et al. ${ }^{9}$, em 1995, observaram, através de microscopia eletrônica de varredura, os efeitos do peróxido de carbamida a 10\% sobre a superfície de esmalte dental humano e a força de adesão após o clareamento. Os dentes foram clareados por oito horas diárias, durante três semanas consecutivas. Após $72 \mathrm{~h}$ do tratamento clareador, foi feita a análise pela microscopia, onde foram encontradas alterações morfológicas na superfície do esmalte, ficando evidente a presença de algumas áreas com variados graus de porosidade, bem como áreas de superfícies bem aplainadas. Os autores salientam que tais alterações não foram uniformes em toda a superfície do esmalte e também constataram a diminuição na força de adesão de compósitos às superfícies de esmalte recém-clareados, sugerindo uma semana de espera para que o potencial remineralizador da saliva minimize os efeitos do clareamento.

LEE et al. ${ }^{50}$, em 1995, estudaram os efeitos do peróxido de hidrogênio a 50\% Accel Brite Smile e de dois tipos de peróxido de hidrogênio a 35\%, sobre a microdureza do esmalte e, observando através de microscopia eletrônica de varredura, uma possível influência desses compostos nos aspectos morfológicos da superfície do esmalte. Todos os grupos foram clareados por uma hora e tiveram a microdureza e a cor mensurados, posteriormente foram clareados por mais uma hora e novas mensurações foram realizadas. Na microscopia eletrônica de varredura todos os espécimes, com exceção do grupo controle, apresentaram alteração no aspecto superficial do esmalte. No grupo clareado com o peróxido de hidrogênio a $50 \%$, o esmalte apresentou-se com densidade relativamente aumentada na superfície das fossas e depressões e pobre definição das periquimáceas; nos outros dois grupos clareados com o peróxido de hidrogênio a 35\%, as periquimáceas superficiais apresentaram uma imagem com melhor definição e maior densidade superficial das fossas em relação ao grupo controle. Mesmo diante desses 
resultados, os autores afirmam que, não houve diferença estatisticamente significante entre os agentes clareadores utilizados, ou seja, a concentração ou a marca comercial não influenciaram no resultado obtido. Entretanto, o peróxido de hidrogênio de maior concentração promoveu maiores alterações na superfície do esmalte e diminuição da microdureza.

Em 1996, ERNEST; MARROQUIN; ZONNCHEN ${ }^{19}$ observaram, através da microscopia eletrônica de varredura, a aparência da superfície do esmalte após o clareamento. Foram utilizados quatro agentes clareadores: um à base de peróxido de carbamida a 10\% (durante 6 horas); dois à base de peróxido de hidrogênio a 30\% (durante $30 \mathrm{~min}$ ) e um com peróxido de hidrogênio associado ao perborato de sódio. Dois espécimes de cada grupo foram utilizados como controle positivo (tratado com ácido fosfórico a $37 \%$ por 30 segundos) e negativo (não recebeu nenhum tratamento); o pH das soluções estudadas foi medido, encontrando-se os valores médios de 2, para o peróxido de hidrogênio a 30\%, 8 para a mistura peróxido de hidrogênio a 30\% + perborato de sódio, 6 para o peróxido de carbamida a 10\% e 1 para o ácido fosfórico. Comparando o aspecto das superfícies tratadas com as do controle, observaram que o esmalte exposto aos agentes clareadores sofreu pequenas ou nenhuma alteração morfológica superficial, ao passo que, naquelas amostras tratadas com ácido fosfórico a 37\%, as alterações morfológicas sempre mostravam um caráter severo. Concluíram que os agentes clareadores testados podem ser recomendados clinicamente.

JOSEY et al. $^{43}$, em 1996, observaram alterações na superfície e na subsuperfície do esmalte após tratamento clareador com peróxido de carbamida a 10\%. O esmalte foi clareado por 10 horas diárias e, após a remoção do agente clareador, era feita a escovação do fragmento com creme dental por 30s, durante 7 dias. Os dentes controle recebiam o mesmo tratamento, porém sem o agente clareador, que era substituído por saliva artificial. No restante do tempo todos os dentes eram armazenados em saliva artificial. Os autores constataram que houve alterações evidenciadas tanto pela microscopia óptica quanto pela eletrônica de varredura na superfície do esmalte. A microscopia óptica evidenciou perda mineral 
após 24 horas do clareamento, permanecendo por 12 semanas, mesmo os dentes sendo armazenados em saliva artificial demonstraram, que o tempo não promoveu o retorno da aparência superficial normal do esmalte clareado. A MEV mostrou alterações na textura da superfície do esmalte clareado. Os autores concluíram que o clareamento resulta em alterações na camada superficial e subsuperfícial do esmalte.

ZALKIND et al ${ }^{83}$, em 1996, investigaram possíveis alterações morfológicas no esmalte, na dentina e no cemento humanos, após a aplicação de alguns agentes clareadores empregados comumente no clareamento dental. Utilizaram dentes humano, os quais foram embebidos no respectivo material clareador e armazenados a $37^{\circ} \mathrm{C}$ durante 7 dias. Os grupos experimentais foram: I) solução de peróxido de hidrogênio a 30\%; II) pasta de perborato de sódio + água ( $2 \mathrm{~g} / \mathrm{ml})$; III) solução aquosa de peróxido de carbamida a 10\%; IV) Nu-Smile; V) Opalescence; VI) DentBright; VII) controle, tratado com solução salina. Sob a microscopia eletrônica de varredura, os autores observaram que ocorrem alterações morfológicas nas estruturas dentárias após o tratamento com a maioria dos materiais clareadores, sendo que o cemento foi o tecido mais afetado, e os agentes à base de peróxido de hidrogênio a 30\% causam as mais severas alterações em esmalte, dentina e cemento, recomendandose muita cautela durante o uso de tais produtos.

MCCRACKEN; HAYWOOD ${ }^{55}$, em 1996, mensuraram a quantidade de cálcio removido da superfície do esmalte clareado com peróxido de carbamida a 10\% em humanos. Alguns fragmentos de esmalte foram imersos em solução de peróxido de carbamida a $10 \%$ e água, por um período de seis horas, outros foram imersos em refrigerante comercialmente disponível, por um período de 2,5 minutos e alguns permaneçam em água destilada, servindo como controle. Os dentes expostos a solução de peróxido de carbamida a 10\% apresentaram significante perda de cálcio quando comparado ao grupo controle. A análise estatística permitiu informar que, não houve diferença estatisticamente significante entre, a quantidade de cálcio perdida dos dentes imersos por 2,5 minutos em refrigerantes, e os dentes tratados com peróxido de carbamida a 10\%. Os resultados sugerem que embora, ocorressem 
alterações na superfície do esmalte após a aplicação do produto clareador, seu significado clinico deveria ser re-examinado, visto que quantidades similares de cálcio são perdidas com a exposição do dente a refrigerante por 2,5 minutos. Os autores concluíram que a quantidade de cálcio perdida com o uso do peróxido de carbamida a $10 \%$ é pequena e provavelmente não tenha um significado clínico relevante.

PINHEIRO JR. et al. ${ }^{67}$, em 1996, examinaram o efeito de cinco agentes clareadores à base de peróxido de carbamida sobre a microdureza do esmalte. Os espécimes de esmalte foram clareados por 8 horas diárias, durante uma semana, nos intervalos entre o clareamento permaneciam em imersos em saliva artificial por 16 horas a $37^{\circ} \mathrm{C}$. O teste de microdureza foi realizado antes e após o clareamento, demonstrando que o agente clareador à base de peróxido de carbamida diminui a microdureza do esmalte humano e que o peróxido de carbamida a 16\% foi o agente clareador que mais diminuiu a microdureza do esmalte. Os autores acreditam que essa redução deve-se a dois fatores: à ação do peróxido na matriz orgânica do esmalte, ou aos agentes ácidos ou quelantes presentes nas fórmulas dos géis clareadores.

Em 1997, FLOYD ${ }^{21}$ abordou vários aspectos da ação dos peróxidos e dos radicais de oxigênio livre, que são denominados espécies de oxigênio reativo, sobre os tecidos de quaisquer sistemas vivos que usam oxigênio. Essas substâncias estão presentes dentro de diversos tipos de células, em baixas concentrações, porque existem sistemas protetores antioxidantes que previnem seu acúmulo. Após afirmar que os peróxidos usados para clarear dentes podem causar danos, se usados inadequadamente, descreveu informações básicas sobre a ação dos peróxidos nos tecidos corpóreos, as quais o dentista poderia usar para executar, de forma segura, o clareamento dentário com essas mesmas substâncias. Citou, entre outros aspectos, que o peróxido de hidrogênio era decomposto pela catalase em água e oxigênio, enquanto a peroxidase o fazia em oxigênio e diversos produtos de oxidação, e a recém-descoberta enzima superóxido-dismutase apontou o fato de que os radicais livres de oxigênio e o peróxido de hidrogênio são importantes 
subprodutos no metabolismo do oxigênio. Acentuou que em todos os sistemas biológicos aeróbicos existe um estado de equilíbrio metabólico entre a capacidade de defesa antioxidante e o potencial de dano oxidativo, apontando quatro pontos importantes a respeito das respostas teciduais diante dos fenômenos de caráter oxidativo: 1) as células normalmente são submetidas a grandes quantias de tensão oxidativa por causa do seu metabolismo normal; 2) a susceptibilidade das células a essa tensão depende, dentre outros fatores, da sua idade e da sua reserva de substâncias antioxidantes; 3) tecidos inflamados contêm leucócitos que, ao realizar fagocitose, produzem radicais de oxigênio livre e assim expõem os tecidos vizinhos a uma tensão oxidativa adicional e 4) danos oxidativos significantes das moléculas, acima dos níveis basais, indicam excessiva tensão oxidativa. Deixou registrado que as tensões oxidativas têm sido classificadas em três categorias (de níveis respectivamente, baixo, moderado e intenso), as quais salientou que os dentistas têm efetuado um uso prudente dos peróxidos e que o uso do peróxido de carbamida com moldeira é um tratamento adequado, que requer prática e conhecimento, pois esses fatores diminuem a possibilidade de graves danos oxidativos na cavidade oral.

HAYWOOD ${ }^{36}$, em 1997, ressaltou as vantagens, desvantagens e formas de utilização dos géis clareadores na técnica de clareamento caseiro, a qual envolve o uso de peróxido de carbamida á 10\% em moldeira durante o dia ou á noite. Afirmou que o tratamento deveria ser realizado sob a supervisão do dentista, para a realização de um correto diagnóstico, avaliação radiográfica das condições pulpares e acompanhamento dos possíveis efeitos colaterais, além de efetuar as eventuais substituições de restaurações. Relatou que o efeito clareador era atribuído á passagem do peróxido de hidrogênio e da uréia, através das estruturas dentais. Conclui que a técnica de clareamento caseiro para dentes vitais, é parte integrante de um tratamento restaurador como um todo.

GULTZ, et al. ${ }^{26}$, em 1999, investigaram através da microscopia eletrônica de varredura o efeito de agentes clareadores de alta concentração e ativação pelo calor ou pela luz, para uso em consultório, e de um condicionador ácido, sobre a superfície morfológica do esmalte. Dentes humanos foram divididos em quatro 
grupos: 1) controle, sem nenhum tratamento; 2) peróxido de carbamida a $35 \%$ ativado por calor; 3) peróxido de hidrogênio a 35\% ativado por luz; 4) ácido fosfórico a 35\%. Todos os produtos foram aplicados de acordo com as recomendações do fabricante: o gel à base de peróxido de carbamida a 35\%, foi aquecido em água por 2 a 3 minutos e colocado em moldeira, permanecendo por 1 hora, removido e reaplicado por mais 1 hora; o agente clareador à base de peróxido de hidrogênio a $35 \%$ fotossensível foi, colocado na superfície do dente e ativado com luz halógena por 4 a 5 minutos, em duas aplicações, e o ácido fosfórico a 35\% foi aplicado por 15 a 20s. Segundo os autores, não foram observadas alterações nos dentes tratados com os agentes clareadores e o grupo controle, porém o grupo que recebeu condicionamento com ácido fosfórico revelou significante diferença na superfície do esmalte quando comparado aos outros grupos.

SPALDING ${ }^{77}$, em 2000, avaliou in vitro o aspecto morfológico da superfície do esmalte, através da microscopia eletrônica de varredura, e uma possível alteração na permeabilidade dental após tratamentos clareadores diversos. Os produtos selecionados foram o peróxido de hidrogênio a 35\% e o peróxido de carbamida a 10\%, empregados isoladamente e de maneira associada, ou seja, uma aplicação do peróxido de hidrogênio a 35\% e subseqüentemente a complementação com o peróxido de carbamida a 10\%, com aplicações de 12 horas diárias durante uma semana. Pré-molares irrompidos e terceiros molares não irrompidos humanos foram seccionados longitudinalmente no sentido mésio-distal e vestíbulo-lingual, de maneira que foram obtidos quatro fragmentos de cada dente. Três fragmentos passaram pelos processos de clareamento a seguir: 1) tratamento com peróxido de hidrogênio a 35\%, de acordo com as instruções do fabricante, que consistem em aplicação de $1 \mathrm{~mm}$ de espessura do gel clareador e fotoativação por dez minutos, em dois tempos de cinco minutos cada um com luz halógena; 2) tratamento idêntico ao grupo 1, e armazenagem em saliva, durante uma semana; a cada 12 horas os espécimes eram lavados e a saliva trocada; 3) idêntico ao grupo 1 e complementação do clareamento com peróxido de carbamida a 10\%, por 12 horas diárias, durante uma semana, e armazenagem em saliva nos intervalos do clareamento, simulando in vitro a técnica mista de clareamento dental: associação 
da técnica de consultório (peróxido de hidrogênio a 35\%) e a caseira (peróxido de carbamida a 10\%). Durante esse período, os espécimes eram mantidos a uma temperatura de $37^{\circ} \mathrm{C}$, em ambiente úmido, para evitar a desidratação. A autora conclui que existe uma grande variação no padrão morfológico normal do esmalte, porém as alterações observadas foram discretas. Assim, os materiais testados, conforme estabelecido nesse estudo, não trazem grandes implicações clínicas e que estudos adicionais avaliando outras propriedades do esmalte, após a utilização de materiais clareadores, tornam-se necessários.

Em 2000, JUNQUEIRA et al. ${ }^{44}$, avaliaram, através da microscopia eletrônica de varredura e da microscopia de luz polarizada, o efeito da técnica de clareamento sobre o esmalte dental, utilizando o peróxido de carbamida a 35\%. As amostras de pré-molares humanos foram divididas em quatro grupos, onde os dois primeiros (A e B) eram grupos experimentais, os quais receberam condicionamento com ácido fosfórico a 37\%, por 30 segundos (apenas na primeira sessão), seguido de tratamento com peróxido de carbamida a 35\% em três aplicações de 30 minutos cada, em intervalos de sete dias, e os dois últimos (C e D), denominados grupos controle. Entre cada sessão de clareamento, os dentes do grupo A, ficavam armazenados em água destilada, e os do grupo $B$, em saliva artificial, ambos em estufa a $37 \pm 1^{\circ} \mathrm{C}$; os dentes dos grupos controle não receberam nenhum tipo de tratamento e ficaram armazenados durante todo o experimento em água destilada (Grupo C) ou em saliva artificial (Grupo D) a $37 \pm 1^{\circ} \mathrm{C}$. Os resultados evidenciaram que o método de microscopia de luz polarizada (MLP), mostrou-se inadequado para avaliar alterações superficiais do esmalte após tratamento clareador. A análise por microscopia eletrônica de varredura (MEV), revelou alterações morfológicas severas na superfície do esmalte, quando a técnica de clareamento com peróxido de carbamida a 35\% foi empregada, havendo um aumento da porosidade e da rugosidade. Além disso, não observaram diferenças estatísticas na alteração morfológica do esmalte após clareamento e imersão em água ou em saliva artificial.

CIMILLI; PAMEIJER ${ }^{15}$, em 2001, avaliaram as propriedades físicas e a composição química do esmalte após o uso do peróxido de carbamida a 10, 15 e 
16\%, por 6 horas diárias, durante 5 a 10 dias. Utilizando espectofotometria observaram que em todos os grupos, inclusive o controle, há uma diferença estatisticamente significante entre os valores da microdureza da superfície e da subsuperfície do esmalte, esta diferença pode ser atribuída à presença de fluorapatita na superfície do esmalte. Os agentes clareadores utilizados diminuíram significativamente a microdureza e causaram a dissolução de cálcio através da conversão da hidroxiapatita do esmalte, exceto nos grupos clareados com peróxido de carbamida a $10 \%$. Os autores relatam a dificuldade em se determinar in vivo à perda de cálcio e fosfato, uma vez que estes componentes estão presentes na saliva e podem ser repostos no esmalte, através dos processos de remineralização, porém há uma preocupação quanto aos efeitos químicos desses clareadores na prática clínica.

Em 2002, KWON et al. ${ }^{49}$ examinaram os efeitos do agente clareador à base de peróxido de hidrogênio a 30\% sobre a superfície do esmalte bovino, utilizando a microscopia eletrônica de varredura para mensurar as alterações morfológicas da superfície e o UV-VIS-NIR espectofotômetro para mensurar a alteração de cor. Foram selecionados 5 incisivos bovinos, os quais foram imersos no agente clareador por três dias, as mensurações eram realizadas diariamente. Para tal, os dentes eram retirados do agente clareador, lavados em água deionizada e secos com ar. Após a mensuração, eles eram novamente imersos na solução clareadora. A comparação do esmalte bovino clareado e não clareado revelou que as maiores alterações de cor ocorriam no primeiro dia, e a superfície clareada mostrava alterações morfológicas mínimas e disformes com o desenvolvimento de vários níveis de porosidade superficial. Os autores concluíram que o clareamento com o peróxido de hidrogênio a 30\% apresenta alterações de cor favoráveis com mínima alteração morfológica na superfície do esmalte.

RIEHL ${ }^{70}$, em 2002, avaliou a influência de três tipos distintos de agentes clareadores sobre a rugosidade e a microdureza do esmalte bovino. Incisivos centrais inferiores bovino foram divididos em quatro grupos: 1) água deionizada, como controle; 2) peróxido de hidrogênio a 35\%, sendo realizadas duas sessões de 
60 minutos cada e ativado com luz incandescente de 100Watts; 3) Opalescence Xtra, à base de peróxido de hidrogênio a 35\%, em duas sessões de 15 minutos cada e ativado com luz halógena com $1.100 \mathrm{mw} / \mathrm{cm}^{2}$ e 4) Opalescence Regular a 10\%, à base de peróxido de carbamida a 10\%, em sete sessões de 4 horas cada. Os ensaios foram executados antes e depois dos tratamentos. Os resultados demonstraram que os espécimes dos grupos 2 e 3 mostraram alterações nas propriedades estudadas, e o grupo 4 não promoveu nenhuma alteração significativa no substrato. Ocorreu aumento de rugosidade superficial significante quando do uso do peróxido de hidrogênio a 35\% e peróxido de carbamida a 35\%, porém esta rugosidade foi ainda maior no grupo clareado com peróxido de hidrogênio a 35\%. No entanto, esse aumento de rugosidade, não foi observado no grupo clareado com peróxido de carbamida á 10\%. Nos casos de ocorrência de alteração no esmalte, era proposto tratamento com Opalustre (ameloplastia ácida), o qual foi capaz de recuperar os valores iniciais de rugosidade e dureza. O autor conclui que parece haver uma correlação entre concentração, tempo de aplicação e potencial de dano no esmalte, quando se trabalha com peróxidos.

HOSOYA et al. ${ }^{40}$, em 2003, estudou in vitro a influência do clareamento vital na rugosidade e na adesão dos Streptococcus Mutans sobre a superfície de esmalte humano. O mesmo foi seccionado no sentido mésio-distal, obtendo duas faces, uma mantida como controle em solução salina e a outra clareada 1, 3 ou 5 vezes usando um agente clareador à base de peróxido de hidrogênio a 35\% com e sem condicionamento ácido prévio. O agente clareador era colocado por 20 minutos em cada aplicação e o ácido por 20s. Após o tratamento, os espécimes eram armazenados em saliva artificial a $37^{\circ} \mathrm{C}$ por 8 horas, simulando o que ocorre na cavidade bucal. A rugosidade foi mensurada através da média de 5 leituras em cada espécime após cada tratamento. Os espécimes foram colocados em cultura contendo 3\% de glicose e incubados por $72 \mathrm{~h}$. Após esse período, foi realizada a contagem das colônias de $S$. Mutans através do microscópio eletrônico de varredura. Todos os tratamentos clareadores indicaram aumento significativo da rugosidade quando comparados com o grupo controle, porém não houve diferença significante entre os diferentes regimes de tratamento. Os tratamentos com 
condicionamento ácido prévio aumentaram significativamente a adesão de bactérias quanto comparado aos tratamentos que não utilizaram o condicionamento prévio. Concluíram que tanto a rugosidade quanto a adesão dos S. Mutans na superfície do esmalte aumentam após o clareamento vital, porém não encontraram relação entre a rugosidade e a adesão das bactérias.

Em uma avaliação quantitativa da ocorrência de alterações superficiais do esmalte, quando submetido ao clareamento dental noturno por dez dias com peróxido de carbamida 10\% e escovação com diferentes dentifrícios, MENEZES; FIROOZMAND; HUHTALA ${ }^{59}$, em 2003, estudaram a perda superficial do esmalte por meio de uma máquina de ensaio de medição tridimensional. Foram selecionados dentes bovinos, os quais foram seccionados longitudinalmente, obtendo-se duas metades e divididos em três grupos, de acordo com o dentifrício utilizado, Sorriso Branqueador, Sorriso e Close up com micropartículas. As metades mesiais de cada grupo recebeu o tratamento clareador por 12 horas durante 10 dias e três escovações diárias com intervalos de quatro horas, durante dois min; as metades distais de cada grupo receberam apenas a escovação com os respectivos dentifrícios. Os resultados mostraram que a perda superficial foi diferente nos três grupos experimentais; o dentifrício mais abrasivo levou às maiores perdas e a utilização do agente clareador não influenciou na perda superficial de esmalte quando comparado cada dentifrício separadamente. Os autores sugerem que os dentifrícios mais abrasivos podem induzir a uma perda superficial maior do esmalte quando este está sendo submetido ao tratamento clareador. Assim, é aconselhável que o profissional oriente o paciente a não usar, durante o tratamento clareador, dentifrícios que possam conter substâncias ativas mais agressivas.

PIMENTA et al. ${ }^{66}$, em 2003, avaliaram o efeito in vitro da utilização de agentes clareadores de consultório na rugosidade superficial do esmalte. Fragmentos de esmalte bovino foram polidos seqüencialmente, e a rugosidade superficial inicial (Ra) foi obtida através da média de três leituras. Em seguida, foram realizados os tratamentos clareadores de acordo com os grupos: $\mathrm{G1}=$ Apollo Secret, G2 = Whiteness HP, G3 = Whiteness Super, G4 = Opalescence Xtra, G5 = Opalescence 
Quick, G6 = Whiteness Perfect. O tratamento clareador foi realizado por 3 semanas, com uma aplicação semanal, com exceção do G6, que sofreu aplicações diárias por 8h. Os fragmentos permaneceram imersos em saliva artificial pelo restante do tempo. Após esse tempo, foi realizada a avaliação de rugosidade final. Os resultados demonstraram não haver diferença entre os valores iniciais ou entre os valores finais de rugosidade, entretanto demonstrou diferença entre os valores iniciais e finais, de rugosidade, dentro de cada grupo. Os autores concluíram que as técnicas de clareamento de consultório e caseira podem causar um aumento na rugosidade superficial do esmalte dental, dependendo do agente clareador empregado.

Em 2003, WORSCHECH et al. ${ }^{82}$ avaliaram in vitro a rugosidade superficial (RA), em diferentes tempos, do esmalte dental clareado com peróxido de carbamida a 35\% e submetido à escovação com dentifrícios abrasivos. Os fragmentos de esmalte eram expostos ao agente clareador por uma hora semanal, durante 28 dias, permanecendo em saliva artificial no restante do tempo. Todos os dias, mesmo após o tratamento clareador, os espécimes eram submetidos à escovação, durante três minutos, com carga de $200 \mathrm{~g}$ e 250 ciclos/min, de acordo com os seguintes grupos: G1: não escovado; G2: escovado com dentifrício fluoretado abrasivo; G3: escovado com dentifrício não fluoretado abrasivo e G4: escovado sem dentifrício. Concluído o tratamento clareador, os espécimes foram armazenados em saliva artificial por mais 28 dias e continuaram a receber escovação, durante este tempo. A rugosidade (RA) foi mensurada no início e nos intervalos de 7, 14, 21, 28, 35, 42,49 e 56 dias, através da média de três leituras. Os resultados revelaram diferenças estatisticamente significantes na rugosidade superficial em função do tempo. Os grupos escovados com dentifrício aumentaram a rugosidade. No entanto, o processo de escovação não alterou a rugosidade superficial do esmalte clareado, uma vez que não houve diferença estatística entre os G1 e G4. O clareamento com peróxido de carbamida a $35 \%$ não altera a rugosidade superficial do esmalte humano, entretanto, quando associado ao tratamento superficial com abrasivos, ocorre um aumento significante dessa rugosidade. 
SULIEMAN et al. ${ }^{79}$, em 2004, estudaram os efeitos do clareamento com o peróxido de hidrogênio $(\mathrm{PH})$ em alta concentração, sobre a integridade do esmalte e da dentina, em termos de erosão, resistência à abrasão e microdureza. Além disso, os espécimes foram avaliados pela microscopia eletrônica de varredura para observar mudanças morfológicas na superfície do esmalte e da dentina. $\mathrm{Na}$ avaliação da erosão do esmalte, os espécimes foram tratados de acordo com os seguintes grupos: 1) $\mathrm{PH} 35 \%$ com pH 7.0 e ativação com lâmpada de arco de plasma por 6s e mantido por 10 min, em três aplicações na mesma sessão; 2) Imersão em ácido cítrico (AC) 0,3\% com pH 3.2, por 30 min, para os espécimes clareados de acordo com o grupo 1 e espécimes que não sofreram nenhum tratamento; 3) Imersão em água destilada seguindo o protocolo do grupo 2; 4) Aplicação do $\mathrm{PH} 35 \%$ de acordo com o protocolo do grupo 1 e escovado com dentifrício por 1 min. No que diz respeito à abrasão e erosão da dentina, os espécimes foram divididos nos seguintes grupos: 1) escovado com água destilada por 30 min; 2) escovado com PH 35\% por 30 min; 3) imersão no PH 35\% por 30 min e ativado com arco de plasma; 4) clareado de acordo com o protocolo do grupo 3 e escovado com dentifrício por $1 \mathrm{~min}$; 5) embebido em água por 30 min e escovado com dentifrício por $1 \mathrm{~min}$; 6) embebido em suco de laranja por 30 min e escovado com dentifrício por 1 min.. A perda de esmalte e dentina foi mensurada através da perfilometria. Os resultados desse estudo demonstram não haver erosão nas superfícies tratadas com $\mathrm{PH} 35 \%$, porém a dentina tratada com ácido cítrico produziu significativamente mais erosão que os demais tratamentos, não havendo diferença significante nos valores da microdureza do esmalte e da dentina clareados. A microscopia eletrônica de varredura não evidenciou alterações topográficas tanto para o esmalte quanto para a dentina. Os autores concluíram que a utilização do peróxido de hidrogênio, em alta concentração, não causa efeitos deletérios no esmalte e na dentina. Provavelmente, segundo os autores, os estudos que relatam efeitos adversos nessas superfícies, após o clareamento, refletem não o clareamento em si, mas o pH da formulação utilizada. 


\subsection{Propriedades físicas do esmalte bovino}

Com o intuito de avaliar a microdureza superficial perpendicular às lesões de cárie artificial em esmalte humano e bovino ARENDS; SCHUTHOF; JONGEBLOED ${ }^{4}$, em 1980, testaram 110 dentes (60 bovinos e 50 humanos). Segundo os autores, as diferenças entre o esmalte humano e bovino foram pequenas, no entanto o esmalte humano mostrou-se ligeiramente mais duro que o esmalte bovino e um pouco mais poroso.

Por meio de uma extensa revisão de literatura sobre modelos e metodologias para estudos de desmineralização e remineralização do esmalte e da dentina in situ, MANNING; EDGARD ${ }^{54}$, em 1992, consideraram viável a utilização de dente bovino para pesquisas em odontologia. Isso porque o esmalte bovino, principalmente quando sua superfície externa é abrasionada em torno de 100 a $200 \mu \mathrm{m}$, oferece uma superfície muito reprodutível e, por esse motivo, pode ser seguramente utilizado em estudos envolvendo ensaios de microdureza e testes de permeabilidade e quando mensurações em série são requeridas.

MELLBERG ${ }^{58}$, em 1992, realizando uma revisão de literatura sobre os tecidos dentários utilizados como substrato para avaliação de atividade cariogênica e anticariogênica, in situ, afirmou que muitos tipos de dentes não humanos são utilizados para avaliação dos agentes anticariogênicos. No entanto, salvo em raras exceções, apenas o incisivo bovino é utilizado para os estudos in situ, uma vez que o esmalte bovino produz lesões muito semelhantes ao esmalte humano, e o índice de formação de lesão no esmalte bovino permanente é muito próximo ao índice de formação de cárie do dente decíduo humano. Dessa forma, o autor conclui dizendo que o dente bovino pode ser utilizado na avaliação de condições cariogênicas, uma vez que a solubilidade do esmalte humano e bovino são suficientemente parecidas para permitir o uso de dente de boi com o intuito de predizer resultados in vivo. $\mathrm{O}$ dente bovino também apresenta a vantagem de ser conseguido em grande quantidade, oferecer uma superfície extensa, plana, e possuir uma constituição mais uniforme que a do esmalte humano. 
Afirmando haver inúmeros fatores relevantes na avaliação do esmalte tais como a sua porosidade, a conectividade entre os poros, a presença de inibidores da dissolução superficial, a solubilidade do mineral e a superfície disponível para sua desmineralização, ANDERSON; LIVINKIND; ELLIOTT³ ${ }^{3}$, em 1998, fizeram um estudo para avaliar os índices de desmineralização do esmalte dental humano e bovino através de um detalhado mapeamento do processo de perda mineral de ambos substratos com o decorrer do tempo, através de um método denominado pelos próprios autores microradiografias paralelamente integradas. Os resultados mostraram que as superfícies de esmalte apresentam uma perda mineral linear a partir de um determinado momento. Os autores concluem que a perda mineral linear mostrou-se constante nos blocos de esmalte humano e bovino com uma variação grande do conteúdo mineral entre os corpos de prova, mas sem diferenças claras entre ambos os substratos testados.

SATO et al. ${ }^{73}$, em 1999, avaliaram a morfologia do esmalte bovino através da microscopia eletrônica de varredura. Os resultados demonstraram que, assim como no esmalte humano, pode-se verificar no esmalte bovino que os prismas são distribuídos regularmente por vários cristais unidos de diferentes formas: $A$, esmalte radial; $\mathrm{B}$, esmalte tangencial e $\mathrm{C}$, um misto de esmalte radial e tangencial. $\mathrm{O}$ esmalte interprismático é composto por muitos cristais finos e a matriz de esmalte possui algumas pequenas massas calcificadas. Confirmando a semelhança entre os dois substratos (esmalte humano e bovino).

\subsection{Formas de Avaliar o Desgaste e a Rugosidade Superficial do Esmalte}

O marco na odontologia quanto à investigação e preocupação em relação ao desgaste dentário, é atribuída a MILLER ${ }^{60}$, em 1907, o qual considerou os diversos fatores capazes de produzir esse desgaste, como a erosão, abrasão, atrição levando à exposição dentária, muitas vezes ocasionando defeitos em forma de cunha na região cervical dos dentes. Em suas observações clinicas e laboratoriais, enfatizou a avaliação de ocorrências de desgastes por abrasão nos elementos dentários 
submetidos à escovação, com grandes variações de escovas dentais e substâncias abrasivas aplicadas. Verificou-se menor desgaste em esmalte, quando comparado à dentina. Ao avaliar o desgaste em tecido dentário e averiguar a magnitude dos resultados, a curiosidade em relação aos materiais odontológicos restauradores o fez investigar o comportamento de restaurações de ouro fundido, muito utilizadas na época, também constatando o seu desgaste. Esse trabalho iniciou uma série de levantamentos e estudos referentes ao desgaste por escovação, considerando diferentes metodologias e substratos a serem pesquisados.

Uma crescente preocupação com o decorrer dos anos foi notada em relação à abrasividade dos dentifrícios presentes no mercado e os danos que poderiam promover nas superfícies dentárias. Nesse sentido, GRABENSTETTER et al. ${ }^{25}$, em 1958, avaliaram a influência de diferentes abrasivos nas superfícies dentárias, quando submetidos a uma máquina de escovação, utilizando o teste de radiação dentária com neutrons. Os espécimes a serem avaliados foram irradiados com isótopos $\mathrm{P}^{32}$, utilizados para marcação e posterior quantificação por meio de leituras para a medição do desgaste ocorrido após um ensaio de escovação laboratorial. Os abrasivos testados foram: $\mathrm{CaCO}_{3}$, carbonato de cálcio $\mathrm{N}^{0} 1(2,0 \mu \mathrm{m}), \mathrm{CaCO}_{3} \mathrm{~N}^{0} 2$ $(1,8 \mu \mathrm{m}), \mathrm{CaHPO}_{4} 2 \mathrm{H}_{2} \mathrm{O}$, fosfato de cálcio di-hidratado $(8,5 \mu \mathrm{m}), \mathrm{CaHPO}_{4}$, fosfato de cálcio $(11,4 \mu \mathrm{m})$, e $\mathrm{NaPO}_{3}$, metafosfato de sódio insolúvel $(7,4 \mu \mathrm{m})$, sendo o primeiro utilizado como referência. Foram utilizadas escovas de cerdas de nylon de média dureza, sendo a velocidade e a pressão da escova controladas. Duzentos ciclos por minuto, em um total de 2.000 ciclos, foram empregados, sendo a primeira metade escovada com o abrasivo-padrão, e a outra com um dos diferentes abrasivos propostos. Foi verificada a abrasão tanto em dentina como em esmalte. Em esmalte foi significativamente menor, correspondendo a cerca de 1 a $5 \%$ do verificado em dentina. Os autores concluíram que esse teste é mais preciso, rápido e fácil que aqueles dependentes da medida da profundidade dos sulcos provocados pelos abrasivos, pois seu coeficiente de variação foi mais baixo e houve necessidade de um menor tempo de escovação. 
Superfícies de esmalte e de dentina também foram utilizadas como substrato na avaliação de 43 marcas comerciais de dentifrícios para determinar o grau de abrasividade dos mesmos. Esse estudo foi conduzido por STOOKEY; MUHLER ${ }^{78}$, em 1968, utilizando-se da técnica de radiação das amostras. Dentes recentemente extraídos foram selecionados. Escovas de dente de cerdas de nylon de média dureza foram utilizadas a uma carga de $150 \mathrm{~g}$ e a perda de massa também foi calculada após 3.000 ciclos de escovação. O cálcio pirofosfato calcinado foi utilizado como abrasivo de referência. As pastas utilizadas foram preparadas na proporção de 1:2 em peso para dentifrício e solução aquosa de carboxilmetilcelulose a 1\% respectivamente. Um medidor de reflexão foi aplicado para avaliar o brilho das superfícies avaliadas. Pelos resultados obtidos, uma grande variação de abrasividade foi determinada entre os diferentes produtos. Houve correlação entre os resultados obtidos em dentes humanos e dentes bovinos, estes utilizados com finalidade comparativa, bem como os resultados obtidos pelo método de radiação e de perda de massa. Também foram verificados diferentes graus abrasivos para o mesmo dentifrícios de lotes distintos, assim como entre diferentes dentifrício com o mesmo tipo de abrasivo. A capacidade de limpeza do esmalte também foi altamente variável entre os dentifrícios testados. Foi observado maior grau de desgaste em ordem crescente para as fórmulas do tipo líquido ou gel, seguida pela pasta e posteriormente pelo pó.

Sugerindo o uso da análise da superfície do grau de desgaste provocado por a ação abrasiva de dentifrícios, ASHMORE; VAN ABBE; WILSON ${ }^{6}$, em 1972, simulam uma situação laboratorial de escovação. As amostras de dentina, próximas da junção amelocementária, foram escovadas sobre carga de $75 \mathrm{~g}$ a uma velocidade de 100 ciclos por minuto, completando-se 1.000 ciclos. Os resultados foram obtidos pelo índice entre a taxa de abrasividade do abrasivo considerado em relação ao abrasivo padrão (carbonato de cálcio). Variadas formas de carbonato de cálcio foram utilizadas. Foram investigados a reprodutibilidade do teste, a influência do tipo de carbonato de cálcio e o tipo de diluente utilizado, e destas avaliações, o tipo de partícula foi diretamente relacionada aos resultados, o que não ocorre em função do diluente da solução. Consideraram pela metodologia aplicada que este tipo de 
análise retrata a condição considerada de forma fácil e satisfatória, sendo uma análise direta e confiável.

Quando do efeito dos dentifrícios em materiais dentários restauradores, em relação ao desgaste e qualidade de superfície, HEATH; WILSON ${ }^{37}$, em 1974, abordaram uma série de preocupações a serem consideradas, desde a constituição e a ação de cada componente, como ao material a ser estudado. As diferentes metodologias de aplicação de teste, suas variáveis e o tipo de análise a ser efetuada após os procedimentos experimentais complementaram a série de colocações onde os autores demonstram a necessidade de se criarem situações que sejam clinicamente coerentes e relevantes. As diferenças isoladas e a associação desses fatores tornam difíceis a comparação de trabalhos e a aplicação direta dos mesmos.

Com o propósito de analisar os efeitos da abrasividade dos dentifrícios nas diferentes superfícies dentárias, HARTE; MANLY ${ }^{30}$, em 1975, preocuparam-se em avaliar os diferentes fatores envolvidos nesse processo. Com essa finalidade, espécimes de substrato de dentina de dentes humanos de $4 \mathrm{~mm}$ de diâmetro, e 1 ou $2 \mathrm{~mm}$ de espessura, foram escovados utilizando duas diferentes marcas comerciais de escova de dente, cada qual com duas durezas de cerdas, média e dura. Quatro abrasivos de distintos dentifrícios foram avaliados, sendo os abrasivos fosfato de cálcio di-hidratado, sílica, óxido de alumínio e fosfato de cálcio anidro preparados em glicerina e solução aquosa de $2 \%$ de carboxilmetilcelulose. Foram realizados preparos de 20 e 40\% de cada abrasivo, na proporção de 1:1 em peso. O cálcio pirofosfato foi selecionado como abrasivo-padrão. Uma carga de $10 \mathrm{~g}$ foi aplicada no teste em um tempo de 30 segundos com 0,1ml da mistura testada. As escovas de dente foram preparadas de forma a apresentarem apenas um tufo, e a quantificação dos resultados foi realizada pelo método de radiação. Os resultados demonstraram forte influência das escovas, dos abrasivos e das interações entre escovas e abrasivos, além da relação de concentração dos abrasivos. Os grupos com $40 \%$ de concentração dos abrasivos apresentam o dicálcio fosfato anidro com maior potencial abrasivo, seguido da sílica, óxido de alumínio e dicálcio fosfato dihidratado. A sílica e o óxido de alumínio inverteram a ordem de potencial abrasivo 
quando do uso da concentração mais baixa. Foi observada a existência da influência de cada fator avaliado e que o abrasivo exerce fator primordial na ação sobre o substrato testado.

Em 1976, os mesmos autores HARTE; MANLY ${ }^{31}$ verificaram a influência dos fatores relacionados aos estudos de determinação da abravisidade dos dentifrícios. Nessa etapa, verificaram a interferência de diferentes marcas comerciais de escovas dentais, dureza da escova, concentração de abrasivo, temperatura do teste e tipo de diluente na abrasão da dentina. Os espécimes obtidos foram previamente irradiados. Os autores concluíram que a consistência da escova foi mais importante que o abrasivo utilizado, no que diz respeito à abrasão.

O método específico de medir a abrasividade, in vitro, dos dentifrícios, de acordo com o Comitê de Abrasão Laboratorial do Programa de Dentifrícios da Associação Dentária Americana (ADA), foi descrito por HEFFERREN ${ }^{38}$, em 1976. Foram citados aspectos com relação aos cuidados necessários na seleção e preparo dos dentes, irradiação e montagens das raízes, assim como a descrição do funcionamento da máquina de escovação. Além disso, escovas, material abrasivo, preparo do diluente e da solução abrasiva, remoção das amostras do contador radioativo, secagem das amostras, contagem radioativa, cálculo da abrasividade e fatores de correlação foram itens abordados e estabelecidos pelo referido Comitê. Sobre o cálculo da abrasividade, concluiu-se que o método baseado na perda de peso não é recomendado para os tecidos dentários, uma vez que leva a resultados falhos, já que a variação do conteúdo de água deles afeta seriamente a medida da perda de peso pela abrasão. No entanto, é um método satisfatório quando utilizado para materiais restauradores. Segundo o autor, a utilização de perfilômetro foi descartada uma vez que os aparelhos são delicados e caros, sendo que o melhor método seria a contagem radioativa do material desgastado. Também ficou estabelecido que o teste de laboratório é um passo necessário para entender as situações clínicas, considerando o grande número de variáveis que ocorrem in vivo. 
RELDMALN; RYDÉN ${ }^{68}$, em 1979, investigaram a abrasividade de dentifrícios, através da aplicação de feixes de laser de hélio-neônio. Dentifrícios contendo diferentes abrasivos foram testados, polimetilmetacrilato, dióxido de sílica, bicarbonato de sódio, silicato de alumínio e carbonato de cálcio. Os espécimes foram submetidos ao laser, anteriormente à abrasão. A escovação foi efetuada com movimentos recíprocos de $85 \mathrm{~mm}$, com 2.000 movimentos por hora, sob carga de 2,35KN. A solução de dentifrício era reposta a cada 15 minutos e, a cada hora, as placas eram removidas para as mensurações. Após as escovações, notou-se um decréscimo na intensidade de luz refletida. O dióxido de silica e o bicarbonato de cálcio diminuíram a intensidade mas, após algum tempo de escovação, também se verificou um aumento nesta intensidade. As placas escovadas com os demais abrasivos apresentaram contínua redução na intensidade de luz. Pelos resultados, os autores concluíram que os dentifrícios podem agir como agentes polidores, como constatado pelo comportamento dos dentifrícios que apresentaram aumento de intensidade de luz. Quanto mais abrasivo o dentifrício, maior o desgaste.

Com a finalidade de avaliar o comportamento de materiais restauradores diretos, em relação ao processo de desgaste por abrasão, HARRINGTON, et al. ${ }^{29}$, em 1982, submeteram diferentes resinas compostas, cimentos de ionômero de vidro, cimento de silicato e amálgama ao teste de escovação in vitro. O equipamento permitiu uma rotação com velocidade de 120 r.p.m. por 25 segundos, com pausa de 5 segundos, rotação no lado oposto por 25 segundos e uma nova pausa após 5 segundos e, assim, sucessivamente. A mistura de pasta com água destilada utilizada era composta pelo carbonato de cálcio como abrasivo, sempre na quantidade de $100 \mathrm{ml}$ para todos os testes. A temperatura de $37^{\circ} \mathrm{C}$ foi mantida constante. Foram utilizadas escovas Oral-B 60, e ao menor sinal visível de desgaste das escovas, procedia-se a sua troca. A superfície foi avaliada através da rugosidade superficial (RA), o peso determinado por uma balança e a espessura medida em micrômetro. Foram efetuadas três séries de 20.000 ciclos cada. As resinas sem carga apresentaram a maior perda de estrutura, o amálgama apresentou superfície melhorada ao final do processo. Segundo os autores, após 120.000 ciclos de escovação, a espessura total perdida é de 13,6 $\mu \mathrm{m}$, enquanto que 
sucedendo mais 120.000 ciclos a espessura perdida aumenta em média mais 2,8 $\mu \mathrm{m}$ apenas. Isso provavelmente ocorre, pois após um certo número de ciclos há um aumento nos valores, devido à degradação da superfície resultante da perda de partículas grosseiras observadas na boca. A razão para esse paradoxo provavelmente deve-se à subjetividade dos testes, uma vez que um ou mais dos seguintes fatores devem ser considerados: 1) realização de testes de escovação insuficientes, uma vez que 240.000 ciclos equivale a, aproximadamente 4 anos de uma escovação normal; 2) ocorrência de diferentes formas de abrasão, como por exemplo, a forma de escovação; 3) a erosão química que provavelmente é influenciada pelo hábito alimentar.

Em uma revisão de literatura, falando da abrasividade ocasionada pelos dentifrícios e pastas profiláticas sobre o tecido dentário, BARBAKOW; LUTZ; IMFELD $^{7}$, em 1987, afirmaram que a marcação radioativa e a perfilometria superficial são os métodos mais largamente utilizados para avaliar o desgaste dental. Entretanto, estes também podem ser feitos através da perda de massa. Segundo os autores, a perda de estrutura advinda da profilaxia está diretamente relacionada à qualidade das cerdas das escovas de Robson e a pressão aplicada durante o procedimento.

MOTTA et al. ${ }^{63}$, em 1998, analisaram o conteúdo abrasivo de 12 dentifrícios, procurando classificá-los em diferentes graus de abrasividade: baixa, média e alta. Cada dentifrício foi pesado e respectivamente processado de modo a eliminar o sabão, possivelmente o sulfato de lauril, através da água e filtragem a vácuo. Ao final, o tratamento utilizou-se de água e álcool etílico para a filtragem. Os resíduos obtidos foram secos em estufa a $45^{\circ} \mathrm{C}$ por duas horas e pesados. Pela fórmula $\mathrm{A}=$ $\mathrm{P} 2 \times 100 / \mathrm{P} 1$, onde $\mathrm{A}=$ abrasividade percentual, $\mathrm{P} 1=$ peso inicial da amostra e $\mathrm{P} 2=$ peso final após a dessecação, foram calculados o grau de abrasividade correspondente a cada dentifrício. Os dentifrícios Kolynos Fresh, Tandy, Kolynos F2, Close-up Refrescante, Colgate Anti-tártaro, Sensodyne apresentaram baixa abrasividade (menor que 20\%); Close-up White, Kolynos Branco demonstraram abrasividade média (20,5 a 30\%) e Phillips, Colgate MFP e Signal foram 
classificados como dentifrícios de alta abrasividade (maior que 30\%). Os autores apontaram para o fato de que a ação de um abrasivo pode ser alterada quando utilizada em conjunto com outro abrasivo ou incorporado dentifrício.

RIOS et al. ${ }^{71}$, em 2002, avaliaram o desgaste e a rugosidade superficial de cimentos de ionômero de vidro utilizados como selantes, após escovação simulada. A determinação do desgaste foi obtida através da quantidade de massa perdida, mensurada por uma balança eletrônica, antes e após o teste de abrasão, realizado por meio de 100.000 ciclos de escovação simulada. Os espécimes eram pesados em intervalos de 24 horas até que não houvesse variação na massa por embebição. A rugosidade (RA) foi determinada através da média de 5 leituras por meio da análise quantitativa da superfície, utilizando o rugosímetro Hommel Tester T1000, antes e após escovação simulada, sempre depois dos espécimes terem atingido massa constante. Os autores concluíram que os ionômeros de vidro na forma cimentante ou diluído, possuem resultados inferiores quando comparados aos ionômeros restauradores que, por sua vez, possuem resultados semelhantes ao selante resinoso.

Avaliando o desgaste de diferentes métodos de profilaxia sobre o esmalte bovino hígido e desmineralizado, HONÓRIO ${ }^{39}$, em 2003, realizou análises quantitativas e qualitativas do desgaste. Para a avaliação quantitativa foi utilizado o Rugosímetro Hommel Tester T1000 que, com o auxílio de um software, além dos dados específicos de rugosidade, forneceram os perfis das superfícies testadas. 0 perfil traçado pelo rugosímetro percorreu a superfície dos corpos de prova passando por áreas de esmalte tratado e não tratado. Como o esmalte polido e não tratado se assemelhava a uma linha reta, tornou-se fácil a identificação da região submetida ao tratamento profilático. A perda de estrutura dentária foi quantificada pelo perfil medido da distância em micrometros da linha do plano do espécime até o maior vale da área desgastada. E, para avaliar o desgaste qualitativamente, foi utilizada a microscopia eletrônica de varredura. O autor concluiu que o esmalte demineralizado desgastou mais que o esmalte hígido independente do tipo de profilaxia utilizada, e a 
escova de Robson foi responsável por um maior desgaste quando comparada ao jato de bicarbonato de sódio.

ASENJO-MARTINEZ ${ }^{5}$, em 2004, avaliando o desgaste e a rugosidade superficial de uma resina composta, após escovação simulada, em função de diferentes energias e fontes de luz usadas na polimerização, utilizou o rugosímetro Hommel Tester T1000. Os espécimes eram divididos em duas partes, onde um dos lados sofreria o processo de abrasão e o outro ficava como controle. Para a mensuração da rugosidade superficial (RA), foram realizadas 5 leituras, de forma aleatória, antes e após o teste de abrasão, utilizando os seguintes parâmetros: Tmín. $=0,01 \mu \mathrm{m}, \mathrm{Lt}=4,8 \mathrm{~mm}, \mathrm{Lm}=1,25 \mathrm{~mm}$, T máx. $=8,00 \mu \mathrm{m}$ e Lc $=0,25 \mathrm{~mm}$ (cuttoff). Para avaliar o desgaste, foi utilizado o mesmo aparelho, onde o desgaste foi quantificado pelo perfil medido da distância em micrometros da linha do plano do espécime, que não sofreu abrasão, até o maior vale da área desgastada. Para tal, foram utilizados os seguintes parâmetros: Tmín. $=8 \mu \mathrm{m}, \mathrm{Lt}=10 \mathrm{~mm}, \mathrm{Lm}=9 \mathrm{~mm}$, Tmáx. $=40 \mu \mathrm{m}$ e Lc= $0.00 \mathrm{~mm}$ (cut-off). 
3. PROPOSIÇÃO 


\section{PROPOSIÇÃO}

O objetivo deste estudo foi avaliar, comparativamente, 0 desgaste e a alteração de rugosidade superficial do esmalte de dentes bovinos, após escovação simulada, quando submetidos à ação de um agente clareador de alta concentração com ativação física (fotoativado), por meio do emprego de duas fontes de luz (halógena e híbrida LED e Laser de Diodo) e um agente clareador de baixa concentração (caseiro).

Este trabalho apresenta, como hipóteses nulas, que os agentes clareadores (peróxido de carbamida e peróxido de hidrogênio), com diferentes concentrações, e o emprego de diferentes fontes de luz (Halógena e híbrida LED e Laser de Diodo) para ativação, com diferenças no comprimento de onda e indução de aumento de temperatura, não determinarão alterações morfológicas no esmalte bovino antes e após escovação simulada. 
4. MATERIAL E MÉTODOS 


\section{MATERIAL E MÉTODOS}

\section{1- MATERIAL}

Para a execução deste estudo, dois agentes clareadores foram selecionados: um caseiro, à base de peróxido de carbamida a 16\% (Whiteness Perfect - FGM Produtos Odontológicos), e um fotossensível, para a técnica em consultório, à base de peróxido de hidrogênio a 35\% (Lase Peroxide - DMC Equipamentos). Dois aparelhos com diferentes fontes de luz foram empregados na ativação do agente clareador fotossensível, um convencional de luz halógena (Curing Light 2500 3M/ESPE, Dental Products) e um equipamento composto de luz híbrida à base de LED e Laser de Diodo (Ultrablue IV - DMC Equipamentos).

O quadro abaixo (Tabela 1) apresenta os nomes comerciais e fabricantes dos materiais utilizados.

TABELA 1: Materiais utilizados e seus fabricantes

\begin{tabular}{l|l}
\hline \multicolumn{1}{c|}{ Material e Equipamentos } & \multicolumn{1}{c}{ Fabricantes } \\
\hline Lase Peroxide & DMC Equipqmentos \\
\hline Witheness Perfect & FGM Produtos Odontológicos \\
\hline Curing Light 2500 & 3M/ESPE, Dental Products \\
\hline Sistema Laser Ultrablue IV (LED e Laser de Diodo) & DMC Equipamentos \\
\hline
\end{tabular}

A tabela 2 ilustra a composição básica, o lote, a data de validade e a indicação dos agentes clareadores utilizados neste estudo. 
TABELA 2: Composição, lote, data de validade e indicação dos agentes clareadores empregados.

\begin{tabular}{|c|c|c|c|c|}
\hline Material & Composição básica & Lote & Data Validade & Indicação \\
\hline $\begin{array}{l}\text { Lase } \\
\text { Peroxide }\end{array}$ & $\begin{array}{c}\text { (Solução de dois frascos) } \\
\text { FRASCO A: } \\
\text { Peróxido de hidrogênio a 35\% } \\
\text { FRASCO B: } \\
\text { Espessante } \\
\text { Corante (Juá e Urucum) } \\
\text { Extratos vegetais } \\
\text { Amina terciária } \\
\text { Agente sequestrante } \\
\text { Glicol } \\
\text { Água }\end{array}$ & 01104 & 05/01/2005 & $\begin{array}{c}\text { Clareamento } \\
\text { em } \\
\text { consultório }\end{array}$ \\
\hline $\begin{array}{l}\text { Witheness } \\
\text { Perfect }\end{array}$ & $\begin{array}{l}\text { Peróxido de carbamida a 16\% } \\
\text { Carbopol neutralizado } \\
\text { Nitrato de potássio } \\
\text { Fluoreto de sódio } \\
\text { Umectante (glicol) } \\
\text { Água deionizada }\end{array}$ & 040404 & $04 / 03 / 2006$ & $\begin{array}{c}\text { Clareamento } \\
\text { caseiro } \\
\text { (moldeira } \\
\text { individual) }\end{array}$ \\
\hline
\end{tabular}

Pela análise da tabela 3 pode-se observar o nome comercial, tipo de unidade geradora de luz, comprimento de onda, densidade de potência e abreviatura dos aparelhos utilizados na ativação do agente clareador fotossensível.

TABELA 3: Características dos aparelhos de luz empregados na ativação do agente clareador.

\begin{tabular}{l|c|c|c|c}
\hline $\begin{array}{c}\text { Equipamentos } \\
\text { (nome comercial) }\end{array}$ & $\begin{array}{c}\text { Tipo de unidade } \\
\text { geradora de luz }\end{array}$ & $\begin{array}{c}\text { Comprimento } \\
\text { de onda }\end{array}$ & $\begin{array}{c}\text { Densidade de } \\
\text { potência }\end{array}$ & Abreviaturas \\
\hline Curing Light 2500 & Luz halógena & 400 a $500 \mathrm{~nm}$ & $670 \mathrm{~mW} / \mathrm{cm}^{2}$ & $\mathrm{HA}$ \\
\hline $\begin{array}{l}\text { Sistema Laser } \\
\text { Ultrablue IV }\end{array}$ & $\begin{array}{l}\text { 19 emissores tipo } \\
\text { LED e sistema } \\
\text { laser de diodo }\end{array}$ & 460 a 480nm & $\begin{array}{c}73 \mathrm{~mW} / \mathrm{cm}^{2} \mathrm{cada}^{2} \\
\text { LED e } 200 \mathrm{~mW} / \mathrm{cm}^{2} \\
\text { do laser, totalizando } \\
1587 \mathrm{~mW} / \mathrm{cm}^{2}\end{array}$ & $\mathrm{UB}$ \\
\hline
\end{tabular}


As Figuras 1 e 2 ilustram os agentes clareadores utilizados.

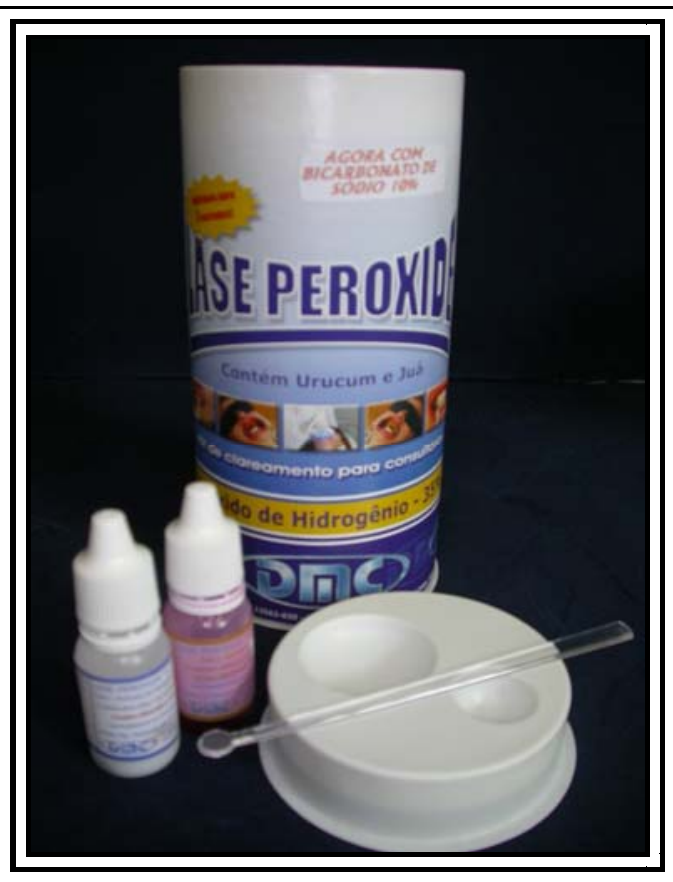

FIGURA 1: Agente clareador à base de Peróxido de Hidrogênio 35\%, Lase Peroxide (DMC Equipamentos), composto de um frasco com peróxido de hidrogênio 35\%, um frasco com espessante, cuba para manipulação e espátula plástica.

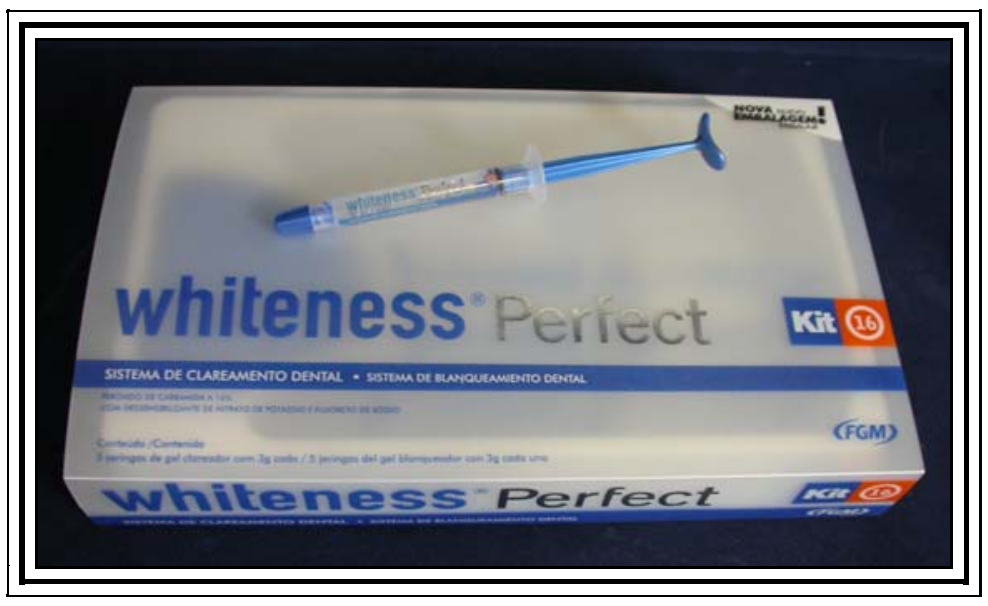

FIGURA 2: Agente clareador à base de Peróxido de Carbamida 16\%, Whiteness Perfect (FGM Produtos Odontológicos), composto por bisnagas com o peróxido de carbamida a $16 \%$. 
As figuras 3 e 4 ilustram os aparelhos fotoativadores.

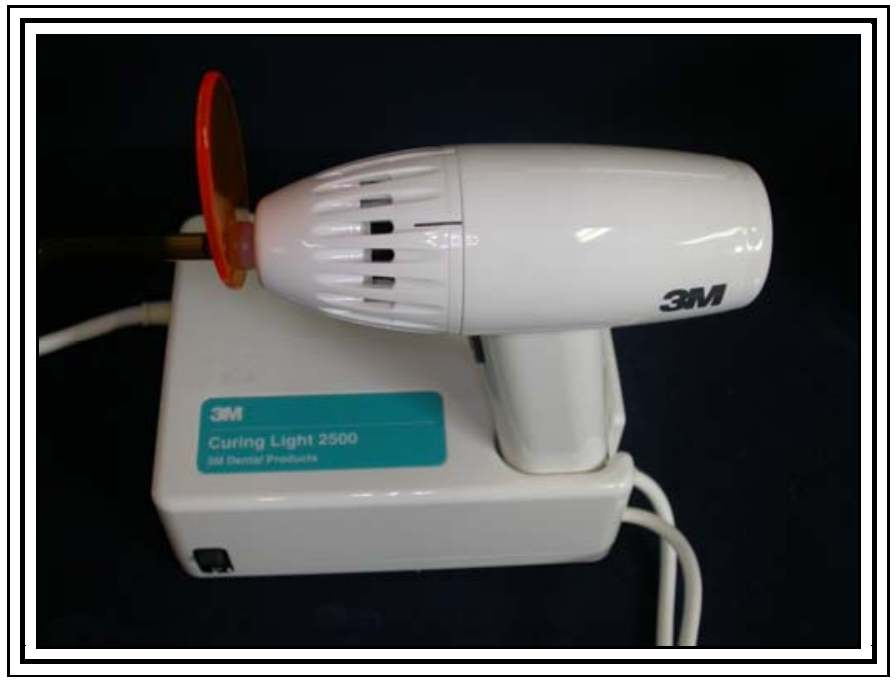

FIGURA 3: Aparelho de Luz Halógena Curing Light 2500 (3M Dental Products).

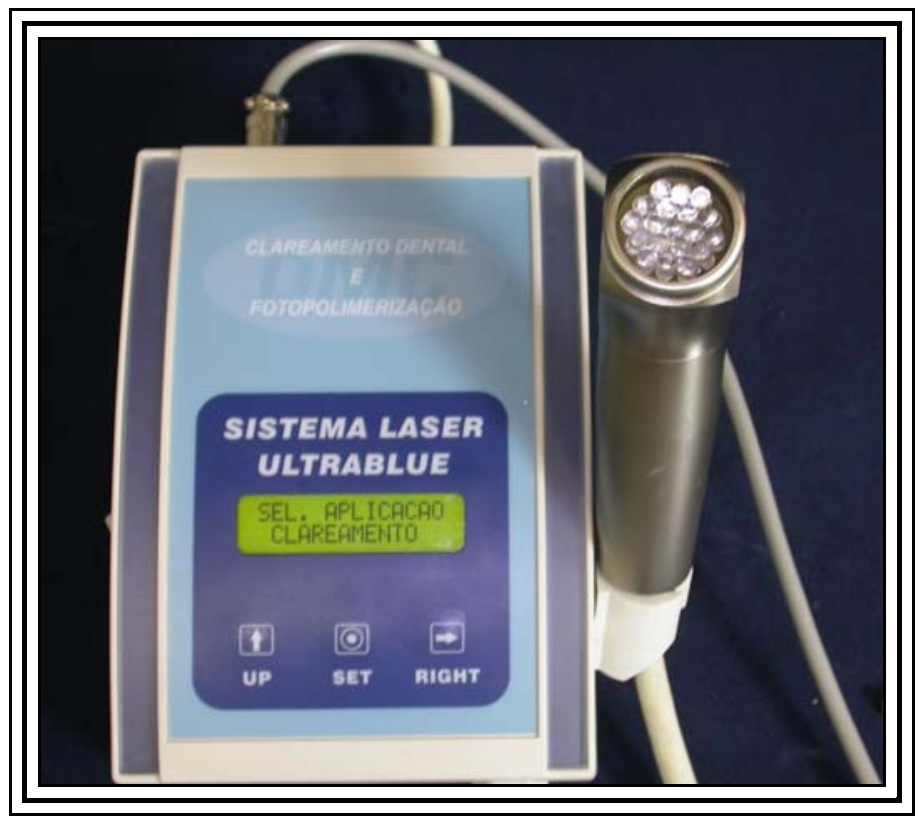

FIGURA 4: Aparelho Ultrablue IV (DMC Equipamentos) composto de luz híbrida à base de LED e Laser de Diodo.

O procedimento de escovação simulada foi realizado com a escova dental Oral-B 30 (Gillete do Brasil Ltda., Manaus-AM, Brasil), com cerdas macias, e dentifrício Colgate MFP (Colgate Palmolive - Divisão da Kolynos do Brasil Ltda., Osasco-SP, Brasil), sendo estes escolhidos por serem consumidos em larga escala 
no comércio nacional (Figura 5). A composição do dentifrício é apresentada na tabela 4.

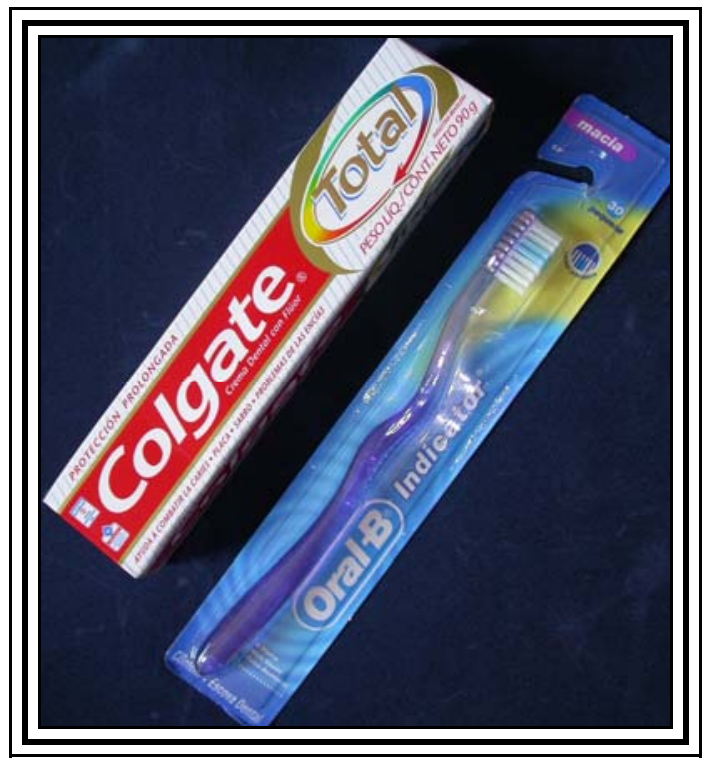

FIGURA 5: Apresentação comercial do dentifrício e escova dental empregados.

TABELA 4: Composição do dentifrício Colgate MFP.

Composição básica do dentifrício Colgate MFP

Monofluorfosfato de Sódio (1500 ppm)

Carbonato de Cálcio

Lauril Sulfato de Sódio

Umectante / Espessante / Aromas / Água

Esse dentifrício é classificado como de média abrasividade (BASTOS, et al. ${ }^{8}$, 1985). As escovas de dente Oral-B 30 (Gillete do Brasil Ltda., Manaus-AM, Brasil) apresentam cerdas de nylon de pontas arredondadas, com oito tufos nas duas fileiras periféricas e sete tufos na fileira central, constituindo um total de três fileiras de tufos.

Todos os materiais e aparelhos ativadores empregados neste estudo estão disponíveis no mercado nacional (Figuras 1, 2, 3, 4 e 5). 


\section{2- MÉTODOS}

\subsubsection{Obtenção da Matriz}

Uma matriz desenhada e fabricada pela escola de Serviço Nacional de Aprendizagem Industrial (SENAI / Bauru) foi desenvolvida especialmente para a obtenção de corpos-de-prova com as dimensões da mesa metálica da máquina de escovação (ANSEJO-MARTINEZ ${ }^{5}$, 2004). É constituída por uma plataforma de aço inoxidável totalmente plana, com dimensões de $50 \mathrm{~mm} \times 45 \mathrm{~mm}$ e $5 \mathrm{~mm}$ de altura, possuindo quatro orifícios estrategicamente posicionados (dois na porção central e dois nas porções laterais) possibilitando, dessa forma, a fixação de dois braços de aço inoxidável com o auxílio de quatro parafusos (Figuras 6 e 7).

Com a remoção dos parafusos laterais, são permitidos aos braços livres movimentos de abertura e fechamento (Figura 8), ideais para a inserção e retirada dos corpos-de-prova. Uma vez fechados, os braços formam em sua porção central uma cavidade com dimensões internas de $15 \mathrm{~mm}$ de comprimento, $5 \mathrm{~mm}$ de largura e $4 \mathrm{~mm}$ de profundidade, medida exata dos espécimes a serem testados.
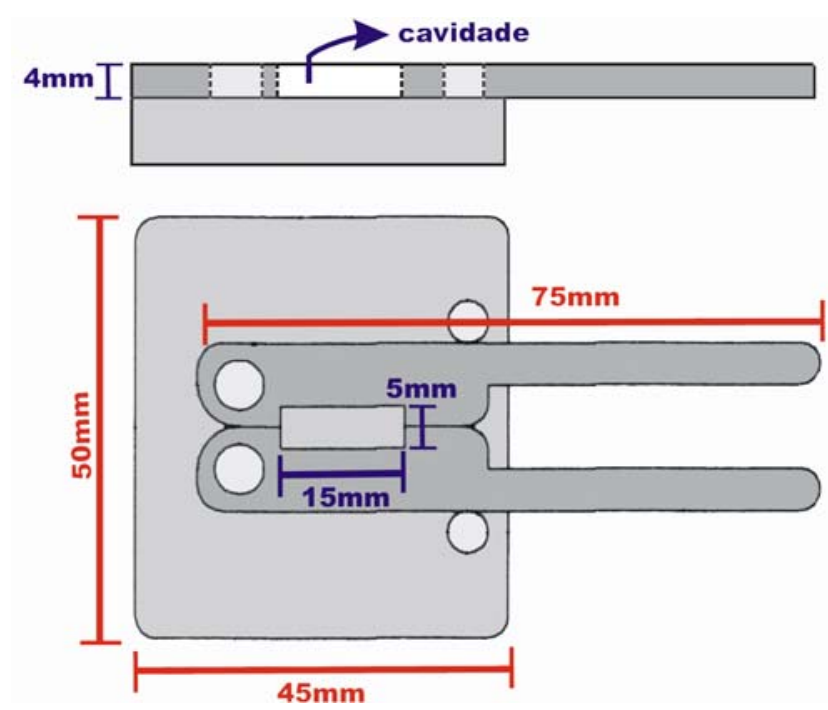

FIGURA 6: Projeto gráfico e medidas da cavidade, braços e plataforma da matriz empregada. 


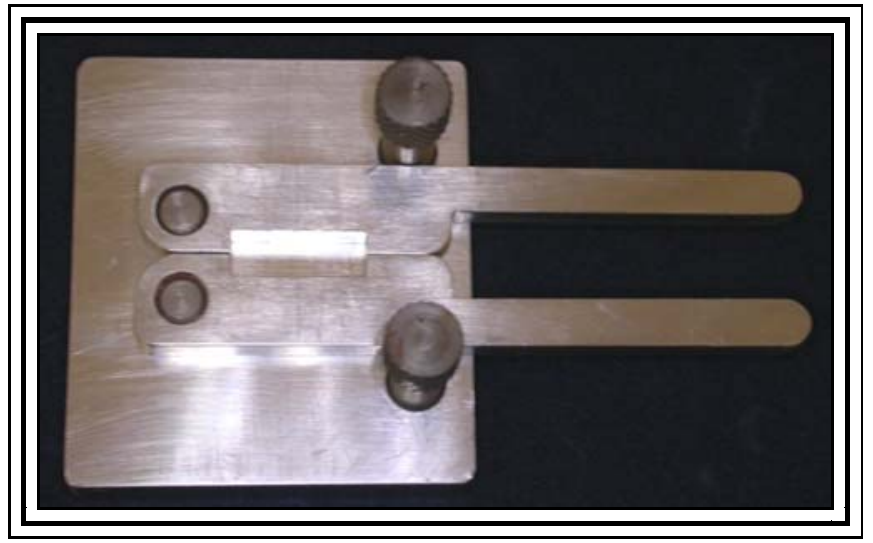

FIGURA 7: Matriz de aço inoxidável utilizada.

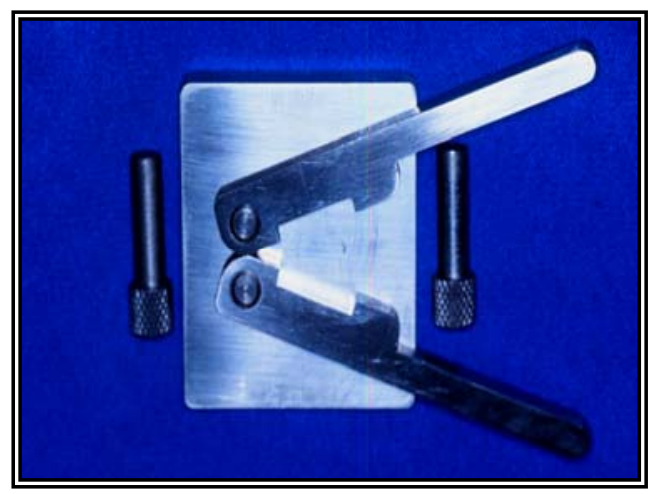

FIGURA 8: Matriz com os braços abertos, após remoção dos parafusos laterais.

\subsubsection{Confecção dos Espécimes}

Foram selecionados dentes incisivos centrais inferiores bovinos (Figura 9), um total de 40 dentes. Todos os dentes foram extraídos imediatamente após o sacrifício dos animais e armazenados em Timol a 0,1\%, contido num frasco de vidro de $500 \mathrm{ml}$, no qual ficaram completamente submersos. Os dentes eram limpos através de profilaxia com escova tipo Robson e pedra-pomes e água, sendo imediatamente devolvidos à solução de timol.

Todos os 40 dentes foram submetidos ao aplainamento da face vestibular, uma vez que a superfície do esmalte bovino apresenta periquimáceas extremamente numerosas e profundas, o que impossibilitaria o registro numérico da rugosidade superficial com o dispositivo de leitura. Tal aplainamento foi realizado com disco de lixa circular, sob refrigeração, com granas em ordem decrescente de granulação: 320,400 e 500, sendo que a cada troca de lixa (grana), o dente era abundantemente 
lavado visando à remoção de grânulos da lixa anterior. Tomou-se o cuidado de manter-se a porção mais plana da face vestibular de cada coroa o mais paralelamente possível, de modo a obter uma superfície plana de esmalte vestibular sem expor dentina (Figura 10 e 11).

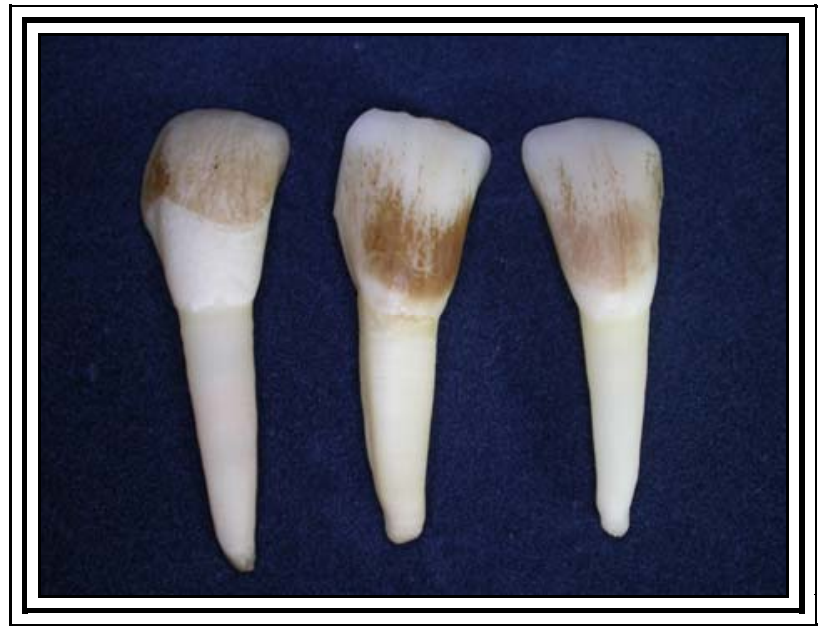

FIGURA 9: Dentes incisivos centrais inferiores bovinos.

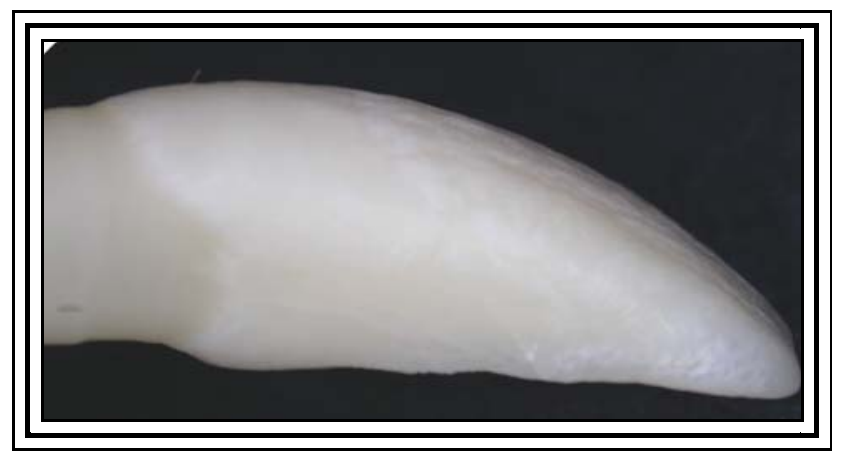

FIGURA 10: Visão lateral da face vestibular antes do aplainamento.

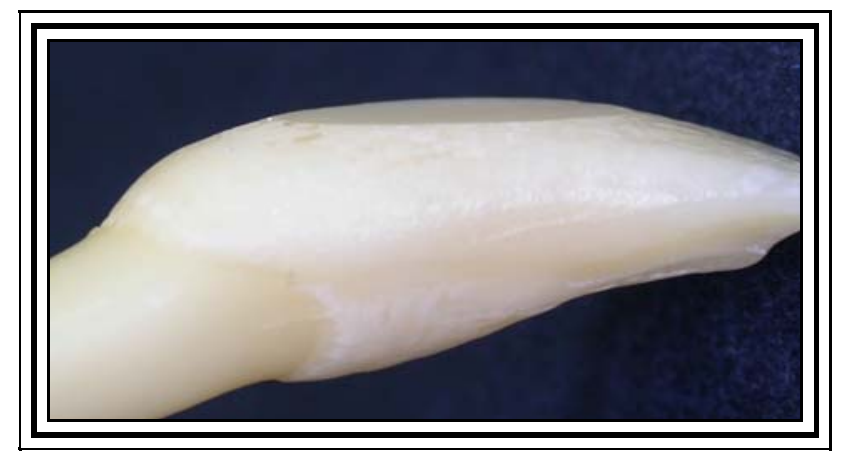

FIGURA 11: Visão lateral do aplainamento da face vestibular. 
Os espécimes foram, então, fixados em cera pegajosa Kota (Kota Ind. e Com. Ltda., São Paulo), com auxílio de um instrumento de PKT (Duflex Ind Bras.) e uma lamparina (JON, Ind. Brás.), no centro de uma matriz metálica apropriada para adaptação na máquina de corte (Isomet 1000/Buehler). Com o auxílio de um disco de diamante, os dentes foram seccionados no sentido vestíbulo-lingual, cortando a porção radicular, incisal, mesial e distal e, posteriormente, longitudinalmente no sentido mésio-distal, excluindo a face palatina (Figuras 12 e 13). Dessa forma, foram obtidos espécimes com $15 \mathrm{~mm} \times 5 \mathrm{~mm}$ na face vestibular e área superficial de $75 \mathrm{~mm}^{2}$.

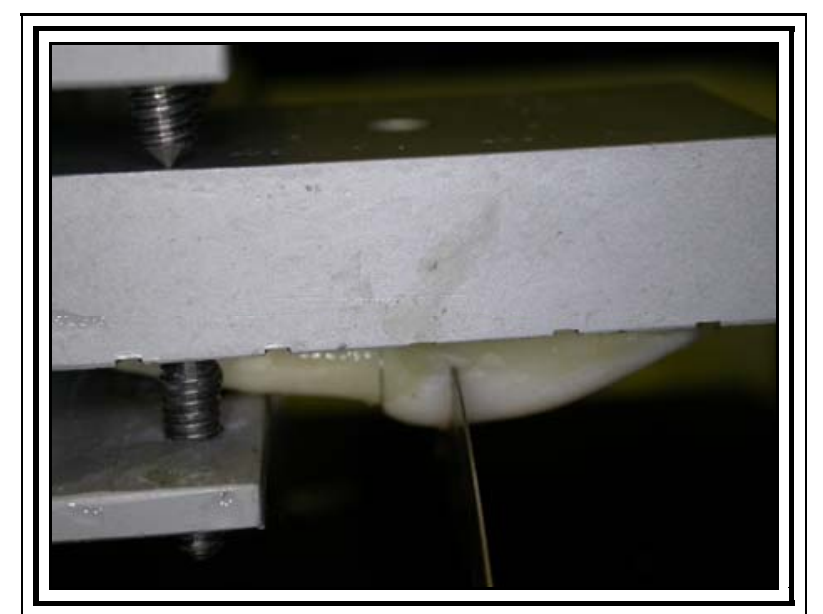

FIGURA 12: Seccionamento no sentido vestíbulo-lingual.

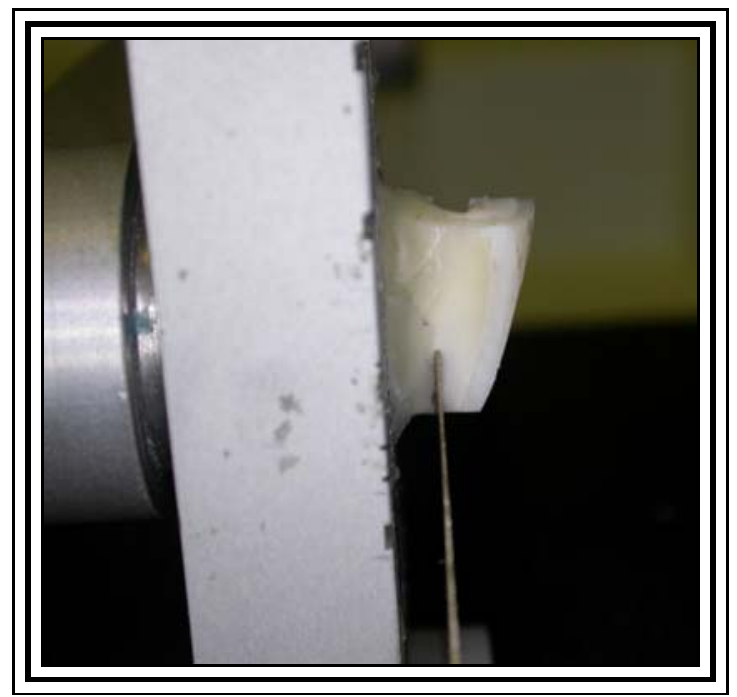

FIGURA 13: Seccionamento no sentido mésio-distal. 
Esse fragmento do dente foi posicionado na matriz com a face vestibular sobre a mesma. Estando a matriz com os braços fechados, a porção interna da face vestibular (câmara pulpar) foi condicionada com ácido fosfórico a 37\%, por 30 segundos, aplicado um sistema adesivo dentinário fotopolimerizável (Primer \& Bond 2.1, Dentsply) e preenchida, com auxílio de uma espátula de inserção apropriada (Hu-Friedy, mini 3, USA), com resina composta fotopolimerizável (TPH spectrum, Dentsply), de forma incremental, com o intuito de se obter o paralelismo entre as bases. Poderia ter sido utilizado qualquer outro material restaurador, que levasse ao paralelismo entre as bases, tais como: resina epóxica, resina autopolimerizável, resina acrílica, entre outros.

Previamente à fotoativação do último incremento, uma tira de poliéster (TDV DENTAL Ltda, Santa Catarina) foi posicionada e, sobre esta, um dispositivo de aço inoxidável (tipo carimbo) submeteu a resina a uma carga axial manual contínua, por 30 segundos, para causar extravasamento do excesso do material. Esse procedimento permitiu obter corpos de prova retangulares com as seguintes dimensões: $15 \mathrm{~mm}$ de comprimento, $5 \mathrm{~mm}$ de largura e $4 \mathrm{~mm}$ de altura (Figuras 14 e 15).

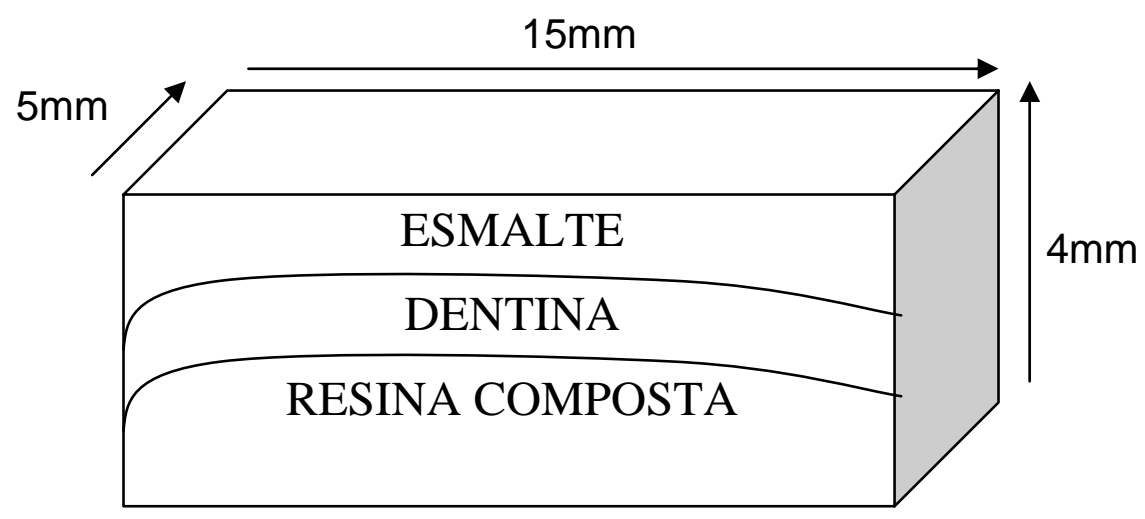

FIGURA 14: Esquema do espécime obtido. 


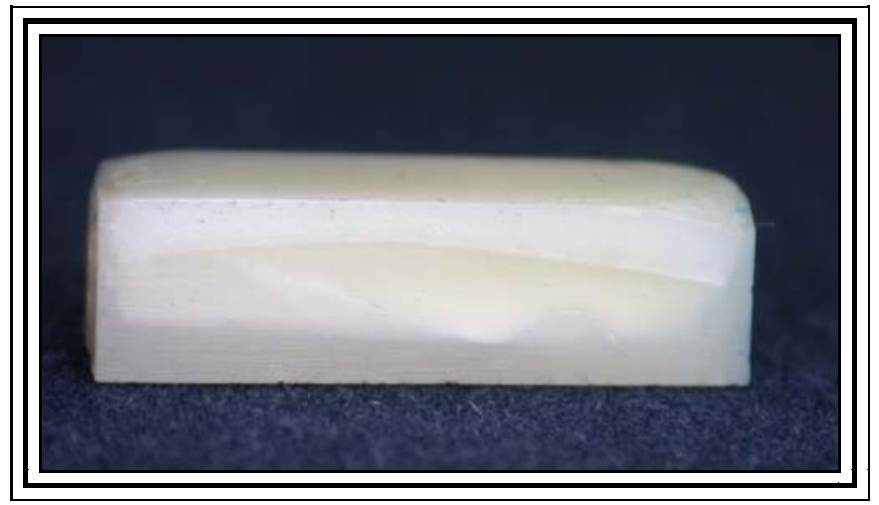

FIGURA 15: Espécimes obtidos após planificação do esmalte e preenchimento da câmara pulpar com resina composta.

Os corpos-de-prova foram divididos em dois segmentos, através da demarcação com esmalte de unhas na face lateral dos espécimes, identificando o segmento teste que receberia o agente clareador e seria escovado, e o segmento controle (Figura 16).

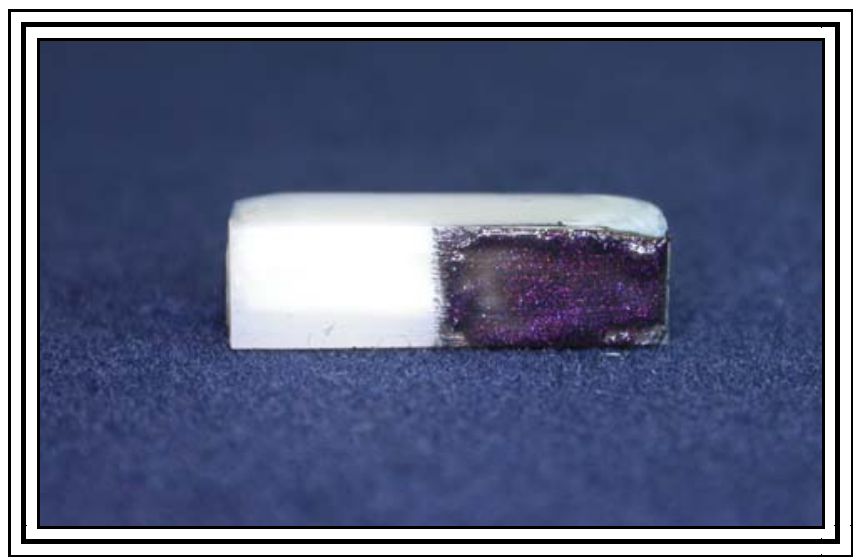

FIGURA 16: Identificação do segmento controle com esmalte de unha.

\subsubsection{Planificação e Polimento dos Corpos de Prova}

Os espécimes foram fixados em cera pegajosa Kota (Kota Ind. E Com. Ltda., São Paulo), com auxílio de um instrumento de PKT (Duflex Ind Bras.) e uma lamparina (JON, Ind. Brás.), no centro de um disco de acrílico (30mm de diâmetro por $8 \mathrm{~mm}$ de espessura), com a face da resina composta voltada para o disco (Figura 17), com o intuito de realizar o polimento do esmalte bovino. 
Para isso, o conjunto (corpo-de-prova/disco) foi adaptado à Politriz Metalográfica (APL4, Arotec, Cotia, SP), com sistema de polimento múltiplo, capaz de realizar o polimento automático de 6 corpos-de-prova (Figura 18), permitindo 0 paralelismo entre as superfícies polidas e a base de acrílico onde os mesmos foram fixados.

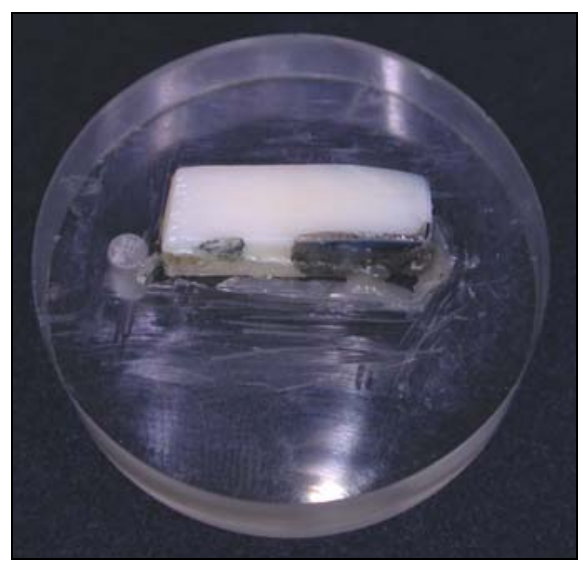

FIGURA 17: Corpo de prova posicionado na matriz.

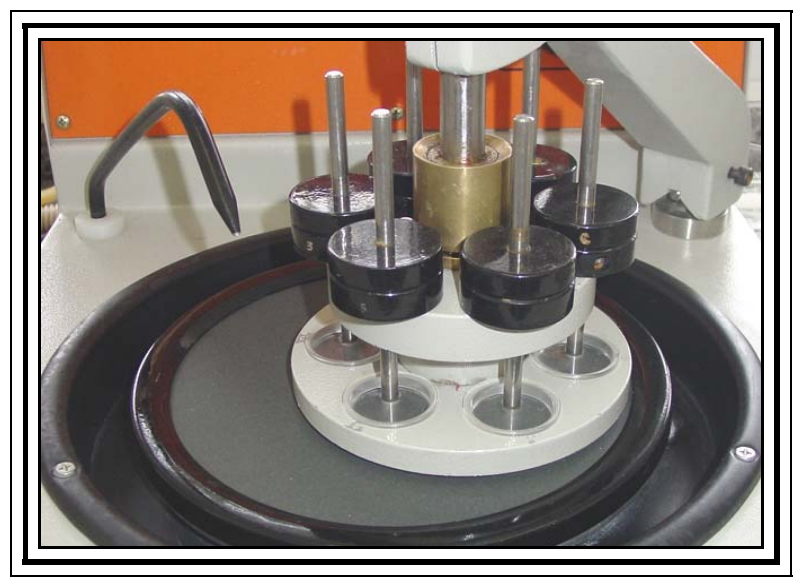

FIGURA 18: Politriz metalográfica APL4, Arotec.

Na planificação da superfície de esmalte, foram utilizadas lixas circulares, sob refrigeração, com granas em ordem decrescente: 500, 600 e 1200 (Extec Corp.). Para tanto, a politriz foi acionada em baixa velocidade, com peso padrão de $172 \mathrm{~g}$, durante 3 minutos para cada grana.

Para impedir que os grãos das primeiras lixas interferissem na qualidade do polimento das seguintes, entre cada etapa do polimento, o conjunto corpo-de- 
prova/disco foi levado a um aparelho de ultrasom T7 Thornton (Unique Ind. e Com. de Produtos Eletrônicos Ltda., São Paulo, SP), com freqüência de $40 \mathrm{KHz}$, durante 5 minutos, com água destilada deionizada.

\subsubsection{Determinação da Rugosidade Superficial Inicial}

Para a realização dos testes de rugosidade superficial foi utilizado o rugosímetro Hommel Tester T1000 basic (Hommelwerke GmbH ref. \# 240851 Schwenningem - Germany), que constitui um aparelho (Figura 19) de alta sensibilidade com ponta ativa de diamante, utilizado para medir rugosidade superficial quantitativamente.

Para cada segmento do corpo de prova foram realizadas cinco leituras de forma aleatória, no sentido transversal e o valor inicial de rugosidade superficial foi obtido através da média aritmética. Regiões onde era nítido algum tipo de irregularidade foram desconsideradas, procurando-se áreas visivelmente de maior regularidade.

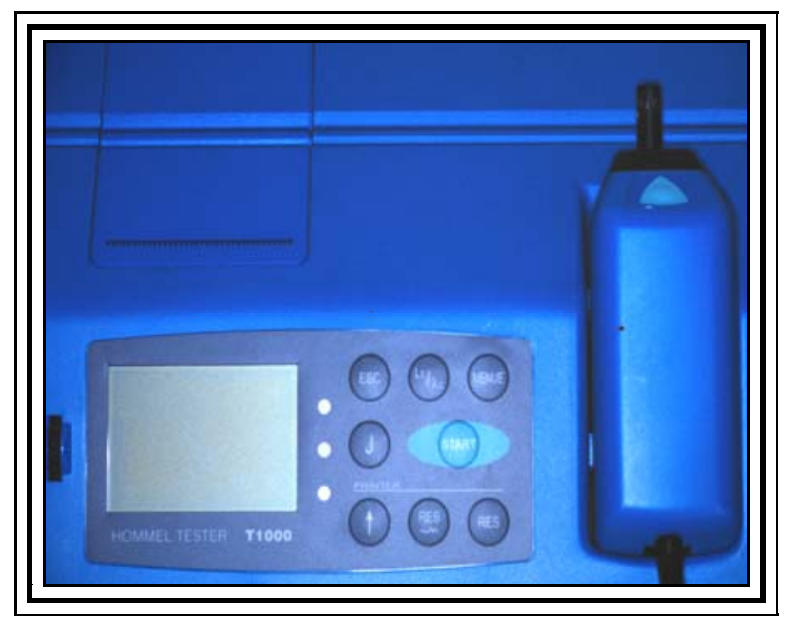

FIGURA 19: Rugosímetro Hommel Tester T 1000.

O parâmetro utilizado para obtenção da rugosidade superficial foi a rugosidade aritmética $(\mathrm{Ra})$ determinada pela média $(\mu \mathrm{m})$ de 5 leituras, escolhido a fim de proporcionar condições de comparação com resultados de outros estudos realizados. Este parâmetro traduz o valor da média aritmética de todas as distâncias 
absolutas do perfil de rugosidade $(R)$ desde a linha central dentro da extensão de medida Lm.

Os parâmetros escolhidos foram:

$$
\begin{array}{ll}
\text { T mínima }=0,01 \mu \mathrm{m} & \mathrm{Lt}=5 \mathrm{~mm} \quad \mathrm{Lm}=4,5 \mathrm{~mm} \\
\mathrm{~T} \text { máxima }=8,00 \mu \mathrm{m} & \mathrm{Lc}=0,25 \mathrm{~mm} \text { (cutt-off) }
\end{array}
$$

Sendo:

$\mathrm{T}=$ tolerância (valores extremos a serem considerados nas leituras)

Lm = limite de medição (extensão considerada da leitura)

Lt = limite de tracejamento (extensão real percorrida pela ponta apalpadora)

Lc = cutt-off (filtragem, minimizando a interferência de ondulação da superfície)

\subsection{5- Grupos a Serem Estudados}

Estando prontos, para cada um dos tratamentos propostos, os 40 corpos-deprova foram divididos aleatoriamente, estabelecendo-se os quatro seguintes grupos de espécimes, cada qual com dez constituintes, conforme a Tabela 5.

TABELA 5: Grupos estudados.

\begin{tabular}{l|l}
\hline GRUPOS & \multicolumn{1}{|c}{ TRATAMENTO } \\
\hline GRUPO I & Controle (saliva artificial) \\
\hline GRUPO II & $\begin{array}{l}\text { Peróxido de Hidrogênio 35\% (Lase Peroxide, DMC) ativado com } \\
\text { luz híbrida (LED e laser de Diodo) Sistema Laser Ultrablue IV } \\
\text { (DMC Equipamentos) }\end{array}$ \\
\hline GRUPO III & $\begin{array}{l}\text { Peróxido de Hidrogênio 35\% (Lase Peroxide, DMC) ativado com } \\
\text { luz halógena Curing Light 2500 (3M/ESPE Dental Products) }\end{array}$ \\
\hline GRUPO IV & $\begin{array}{l}\text { Peróxido de Carbamida 16\% (Whitenees Perfect 16\%, FGM } \\
\text { Produtos Odontológicos). }\end{array}$ \\
\hline
\end{tabular}

O tempo de ativação utilizado para cada grupo foi determinado de acordo com as recomendações dos fabricantes do agente clareador e dos aparelhos. 
Todos os materiais utilizados foram mantidos em condições adequadas, para evitar sua alteração, seguindo-se as instruções dos respectivos fabricantes dos produtos utilizados.

\subsection{6- Clareamento dos Espécimes}

Os espécimes foram submetidos ao clareamento conforme as especificações dos respectivos fabricantes e permaneceram armazenados em saliva artificial.

Todos os procedimentos foram realizados sobre uma bancada de trabalho, em ambiente arejado e com todos os E.P.I. (equipamentos de proteção individual) disponíveis.

O produto Lase Peroxide foi manipulado, em cuba plástica, colocando-se três gotas do agente clareador e uma gota do agente espessante; numa camada uniforme de aproximadamente 1,0mm de espessura, o gel foi depositado sobre a plataforma de esmalte e mantido por 2 minutos, para que ocorresse a penetração do agente clareador nas estruturas dentárias em maior profundidade (MONDELLI ${ }^{62}$, 2003). Imediatamente, à distância de um centímetro da superfície, o gel clareador foi ativado com luz híbrida do aparelho Ultrablue IV (DMC Equipamentos), por $3 \mathrm{~min}$. Após ativação, o gel clareador era agitado para manter-se uniforme e mantido por mais 3 minutos, para que ocorresse o máximo de liberação de oxigênio (LORENZO et al., 1996; MONDELLI, 2003; ZANIN et al., 2003). Foram realizadas 3 aplicações consecutivas, totalizando 9 minutos de fotoativação (Figura 20). A cada novo ciclo o corpo-de-prova era lavado com água deionizada e seco com papel absorvente e, nova porção do gel clareador era aplicada e fotoativada.

No Grupo III o produto Lase Peroxide foi aplicado sobre o esmalte bovino, mantido por 2 minutos e fotoativado com luz halógena (Curing Light - 3M Dental Products), com diâmetro da ponteira de $8 \mathrm{~mm}$ (Figura 21) e densidade de potência de 670 mw/cm², aferida com radiômetro (Curing radioômetro: Model 100 P/N-10503 / Demetron Reserch corp.). Durante $30 \mathrm{~s}$, com intervalo de 30s, até completar 3 min. de ativação com luz, para que a temperatura sobre a estrutura dentária não aumentasse muito, sendo o agente mantido sobre o espécime por mais $3 \mathrm{~min}$. 
Totalizando 3 ciclos de luz, cada um com 3 minutos, com troca do gel clareador a cada novo ciclo.

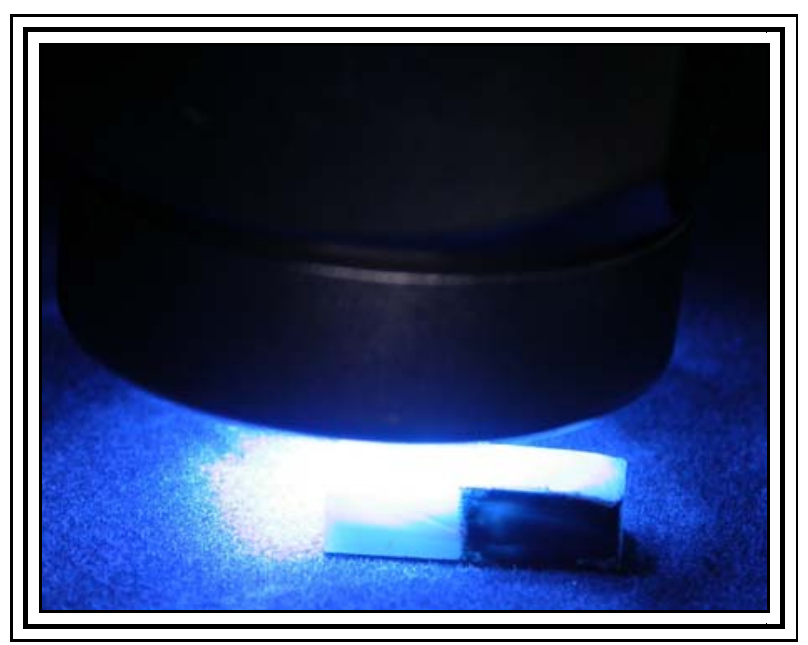

FIGURA 20: Clareamento com luz híbrida.

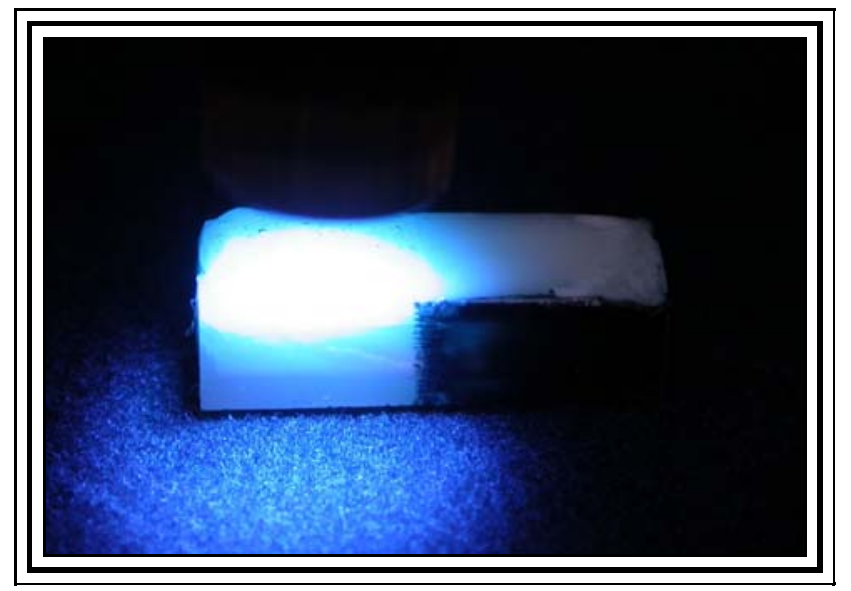

FIGURA 21: Clareamento com luz Halógena.

A solução clareadora à base de peróxido de carbamida a 16\%, Witheness Perfect, foi mantida sobre a porção exposta do esmalte do CP, o qual foi mantido em frascos com gotas de saliva artificial, para manter a umidade em 100\% e permanecia em estufa a $37^{\circ} \mathrm{C}$ pelo período de 2 horas diárias, durante 14 dias. Enquanto não estavam sobre tratamento clareador os corpos-de-prova eram mantidos imersos em saliva artificial, em estufa a $37^{\circ} \mathrm{C}$, simulando um tratamento clareador doméstico completo (Figura 22 e 23). 


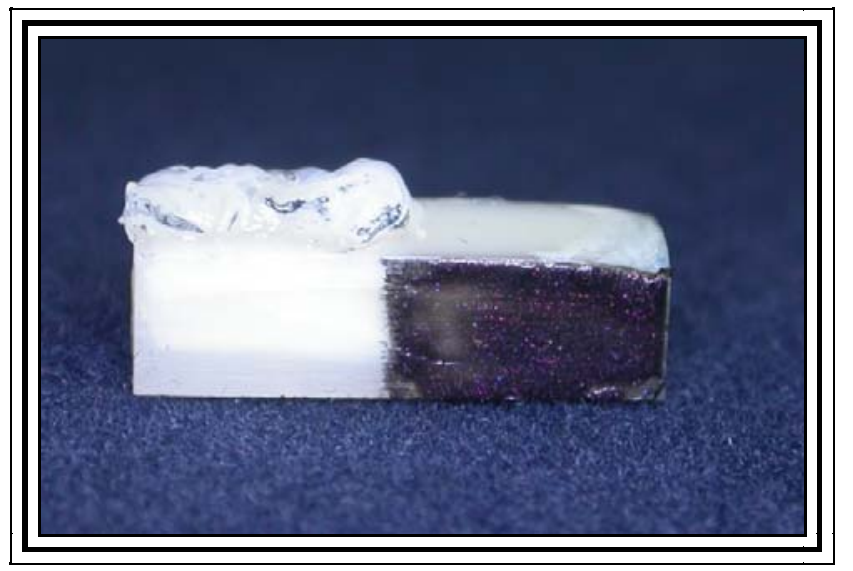

FIGURA 22: Clareamento com Peróxido de Carbamida à 16\%.

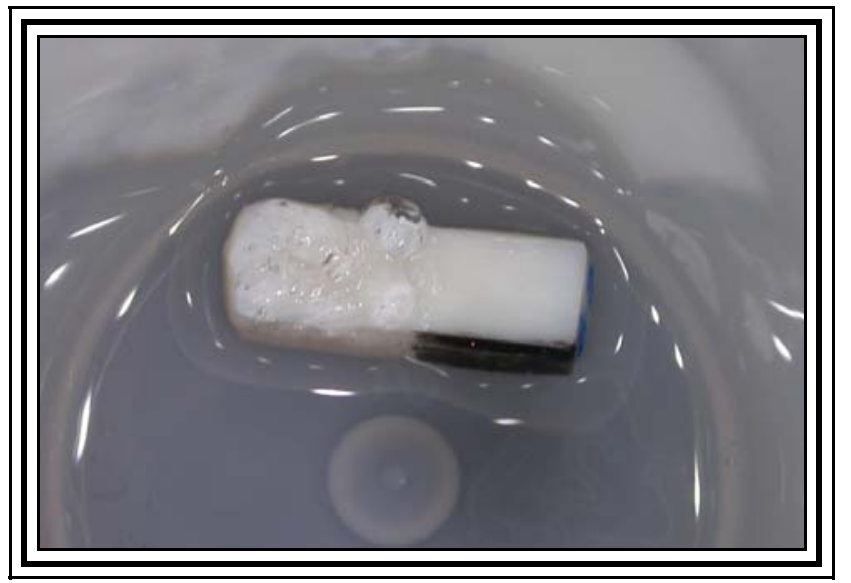

FIGURA 23: Clareamento com Peróxido de Carbamida à 16\%; o corpo-de-prova mantido em frasco com gostas de saliva.

Durante todo o período em que não estavam sendo submetidos aos tratamentos descritos, todos os CP eram mantidos em saliva artificial, especificadamente formulada para remineralização dos tecidos duros dentais e trocada diariamente (PINHEIRO JR. $\left.{ }^{67}, 1996\right)$. A solução remineralizadora é similar a saliva natural em termos de Ca e $\mathrm{P}$ de acordo com o proposto por FEATHERSTONE et al.(1986) e modificado por SERRA; CURY ${ }^{74}$ em 1992. A composição da saliva artificial empregada esta descrita na tabela 6. 
TABELA 6: Composição da saliva artificial.

\begin{tabular}{c|c}
\hline SUBSTÂNCIA & CONCENTRAÇÃO (mmol/L) \\
\hline $\mathrm{PO}_{4}$ & 0,9 \\
\hline $\mathrm{Ca}$ & 1,5 \\
\hline $\mathrm{KCl}$ & 50 \\
\hline Tri-hidroximetil & 20 \\
\hline
\end{tabular}

Após as últimas sessões de cada grupo, os dentes eram lavados em água deionizada, secos naturalmente e logo em seguida, armazenados em frascos contendo saliva artificial e mantidos em estufa a $37^{\circ} \mathrm{C}$, durante 24 horas, a fim de realizar o teste de rugosidade.

\subsubsection{Determinação da Rugosidade Superficial Após o Clareamento}

As leituras de rugosidade superficial, após o clareamento, foram realizadas no segmento do corpo de prova que sofreu o processo de clareamento, seguindo-se a mesma metodologia descrita anteriormente no item 4.2.4.

\subsubsection{Armazenamento dos Corpos de Prova}

Após a determinação da rugosidade superficial inicial, do clareamento e da rugosidade superficial após o clareamento na área teste, os quarenta corpos-deprova foram armazenados em recipientes plásticos brancos, com $5 \mathrm{ml}$ de saliva artificial, hermeticamente fechados, identificados e colocados em estufa a uma temperatura de $37^{\circ} \mathrm{C}$ e umidade absoluta de $100 \%$. Foi aguardado um período de sete dias para a ocorrência de remineralização, com troca diária da saliva artificial, para então ser realizada a escovação simulada.

\subsection{9- Procedimento de Abrasão}

Para a realização dos testes de abrasão foi utilizada a máquina para simulação de escovação (Figura 24), adquirida através de auxilio pesquisa FAPESP 
n : 01/04945-2, idealizada para este propósito, através do protocolo descrito em 2001 por TURSI ${ }^{81}$.

O equipamento consiste em um motor que produz movimentos de vaivém em dez braços, nos quais são fixadas as cerdas de escovas dentais (Oral B 30 - Gilete do Brasil Ltda., Manaus-AM, Brasil) viabilizando simulação simultânea da escovação em dez corpos de prova (Figura 24). A base do equipamento é de aço inoxidável, especialmente desenhada, possui dez orifícios (lojas) independentes para 0 posicionamento dos espécimes, de tal forma que a ação das cerdas da escova dental exerça atrito somente na metade da superfície do espécime que recebeu o tratamento clareador, ficando a outra metade do espécime como controle para se determinar o desgaste após o clareamento e a escovação. As "cabeças" das escovas dentais foram fixadas de forma a garantir o seu alinhamento paralelo à base metálica.

No teste propriamente dito, ou seja, durante a simulação de escovação do material, observou-se a necessidade de posicionar os corpos de prova de forma a estarem salientes em relação à matriz metálica (Figura 25), permitindo melhor atuação das cerdas das escovas, eliminando qualquer interferência.

O equipamento é dotado de um sensor de temperatura que viabiliza a escovação a temperatura de $37 \pm 2^{\circ} \mathrm{C}$ através de monitoramento preciso e livre de interferências externas. A amplitude da excursão dos movimentos de escovação foi ajustada em 20mm, compatível com a dimensão dos espécimes. O ciclo, movimento completo de vai-vem, foi ajustado em um sensor específico do equipamento e adaptado a velocidade de 5,5 ciclos por segundo com carga de $300 \mathrm{~g}$. Durante a escovação, a máquina foi ajustada para injetar freqüentemente, em cada corpo de prova, 0,4ml da solução, de dentifrício com água destilada, a cada dois minutos (Figura 26). 


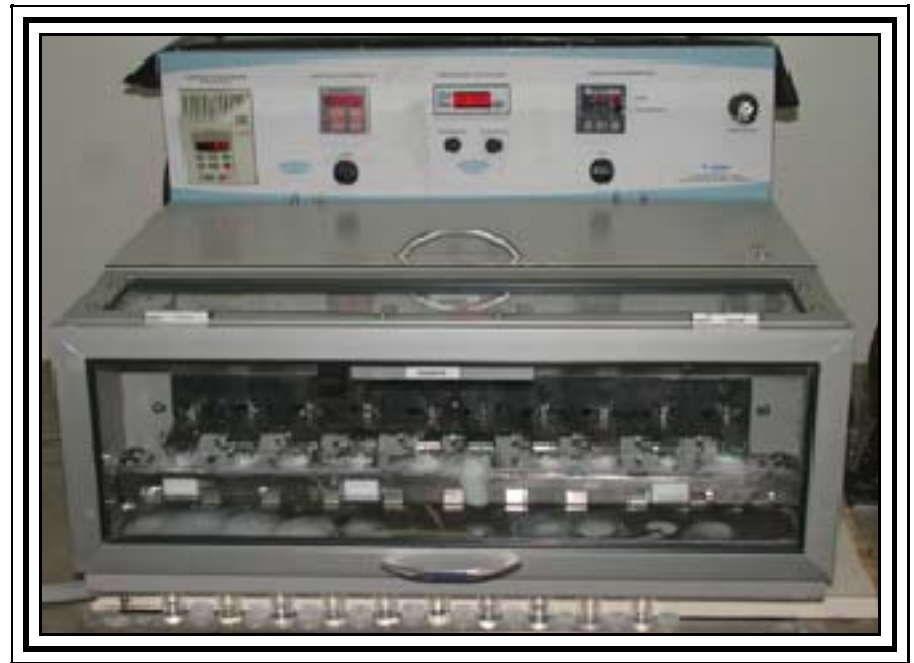

FIGURA 24: Máquina utilizada nos testes de escovação simulada.

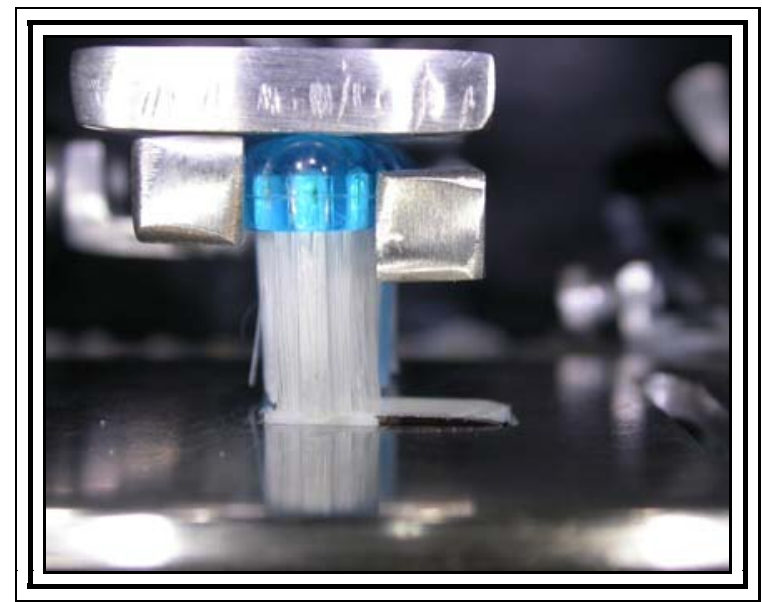

FIGURA 25: Disposição do espécime em relação à barra metálica e à escova dental.

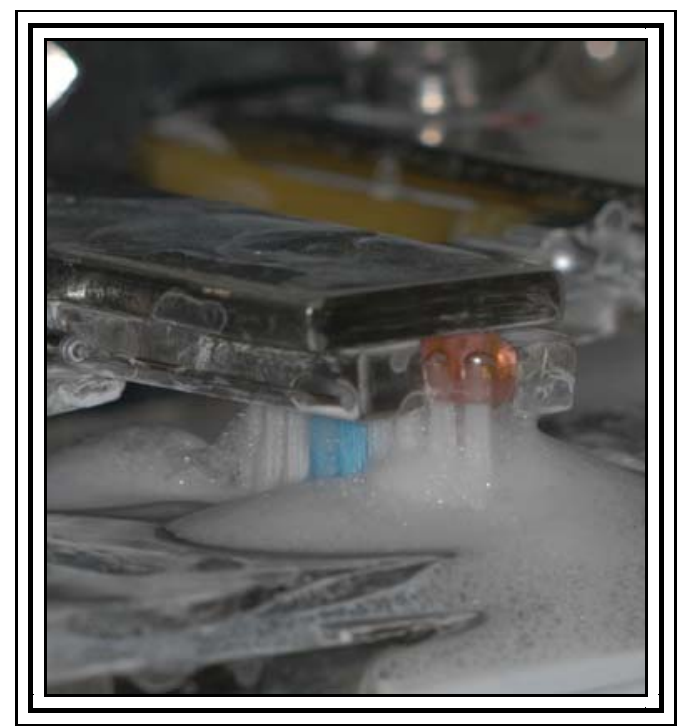

FIGURA 26: Injeção da solução (creme dental + água) durante o procedimento de escovação do espécime. 
A solução consistiu de dentifrício dental Colgate MFP (Colgate Palmolive Divisão da Kolynos do Brasil Ltda, Osasco - SP, Brasil) e água destilada na proporção de 1:2 em peso sendo pesada e diluída no interior de um Becker com água destilada, de acordo com a especificação ISO $^{42}$ (ISO, 1999). O preparo da solução foi realizado imediatamente antes de sua utilização, com a finalidade de preservar suas características (HEFFERREN $\left.{ }^{38}, 1976\right)$.

Para o procedimento de escovação, os espécimes foram escolhidos aleatoriamente e o lado controle demarcado anteriormente com esmalte de unha, este lado foi protegido com fita adesiva. O tempo de ensaio para cada grupo (100.000 ciclos) foi de aproximadamente oito horas. Sendo que a cada 50.000 ciclos as escovas eram substituídas por novas.

\subsubsection{0- Limpeza dos Corpos de Prova}

Após o término dos 100.000 ciclos de escovação, os corpos de prova eram cuidadosamente removidos da matriz metálica e imediatamente lavados em água corrente com auxílio de uma pinça clínica. Em seguida, eram colocados no interior de um aparelho de vibração ultra-sônica T7 Thornton (Unique Ind. E Com. de Produtos Eletrônicos Ltda., São Paulo, SP) por 5 minutos, cujo compartimento central continha água destilada para que as partículas abrasivas do creme dental fossem removidas das superfícies das amostras testadas. Posteriormente foram secados com papel absorvente e armazenados em saliva artificial no interior de recipientes individualizados e identificados à temperatura de $37^{\circ} \mathrm{C}$ e umidade absoluta de $100 \%$, para a determinação da rugosidade superficial final.

\subsubsection{Determinação da Rugosidade Superficial Final}

As leituras de rugosidade superficial final foram realizadas, transversalmente ao sentido de abrasão, no segmento do corpo de prova que sofreu o processo de abrasão, seguindo-se a mesma metodologia descrita anteriormente no item 4.2.4. As diferenças dos valores entre as médias iniciais e finais foram reportadas como a alteração final da rugosidade. 


\subsubsection{2- Determinação do Desgaste Superficial}

Para as leituras de desgaste da superfície dos corpos-de-prova foi utilizado o mesmo aparelho, Hommel Tester T1000 basic (Hommelwerke GmbH ref. \# 240851 Schwenningem - Germany), usado na determinação da rugosidade superficial, como perfilômetro.

A determinação do desgaste foi verificada pela média de três leituras dos perfis reais das superfícies de cada corpo-de-prova obtidos por meio do perfilômetro. Com intuito de possibilitar a realização dos ensaios de desgaste, foi necessário o polimento com a politriz metalográfica (Figura 19), das áreas a serem mensuradas. O objetivo foi obter um perfil o mais próximo possível de uma linha reta. Passando a ponta apalpadora do rugosímetro pela metade demarcada (lado controle) e pela metade não demarcada (lado do escovado). Desta forma, como o perfil do lado controle sempre se assemelhará a uma linha reta, pelo fato de estar protegido e não ter recebido tratamento clareador e escovação, toda alteração visualizada seria resultado do processo de clareamento e de escovação a qual os espécimes foram submetidos (lado escovado). Assim sendo, pode-se visualizar e mensurar o desgaste dos corpos-de-prova dos 4 grupos testados.

O rugosímetro (Figura 18) foi conectado a um microcomputador que processava todas as informações pertinentes aos ensaios. Com o auxílio de um software do equipamento (Turbo Datawin-NT, Versão 1.34, Copyright (c 2001) além dos dados específicos das rugosidades superficiais, foram obtidos também os perfis reais das superfícies testadas, sendo estes importantes para a ilustração e quantificação do desgaste. Foram feitas três mensurações para se obter a média do desgaste (ANSEJO-MARTINEZ ${ }^{5}$, 2004).

Para padronização efetiva da distância, que precisava ser percorrida pela ponta apalpadora do aparelho, e da programação do mesmo, através do parâmetro Lt (limite do tracejamento), foram feitas duas linhas na lateral dos espécimes, as quais serviram de orientação no posicionamento da ponta apalpadora no início das leituras.

Desta forma, o perfil traçado pelo rugosímetro percorreu a superfície dos corpos-de-prova passando pela metade demarcada com esmalte de unha (lado 
controle) e pela metade não demarcada (lado escovado). Como o lado controle não foi escovado e se assemelhava muito a uma linha reta, tornou-se fácil à identificação da região submetida à escovação (lado escovado). Assim sendo, a perda de tecido mineralizado foi quantificada pelo perfil real medindo-se à distância em micrometros $(\mu \mathrm{m})$ da linha média do gráfico, correspondente à linha do plano da área demarcada (lado controle) do espécime, até o maior vale correspondente à área escovada (Figura 27) (HONÒRIO ${ }^{39}$, 2003).

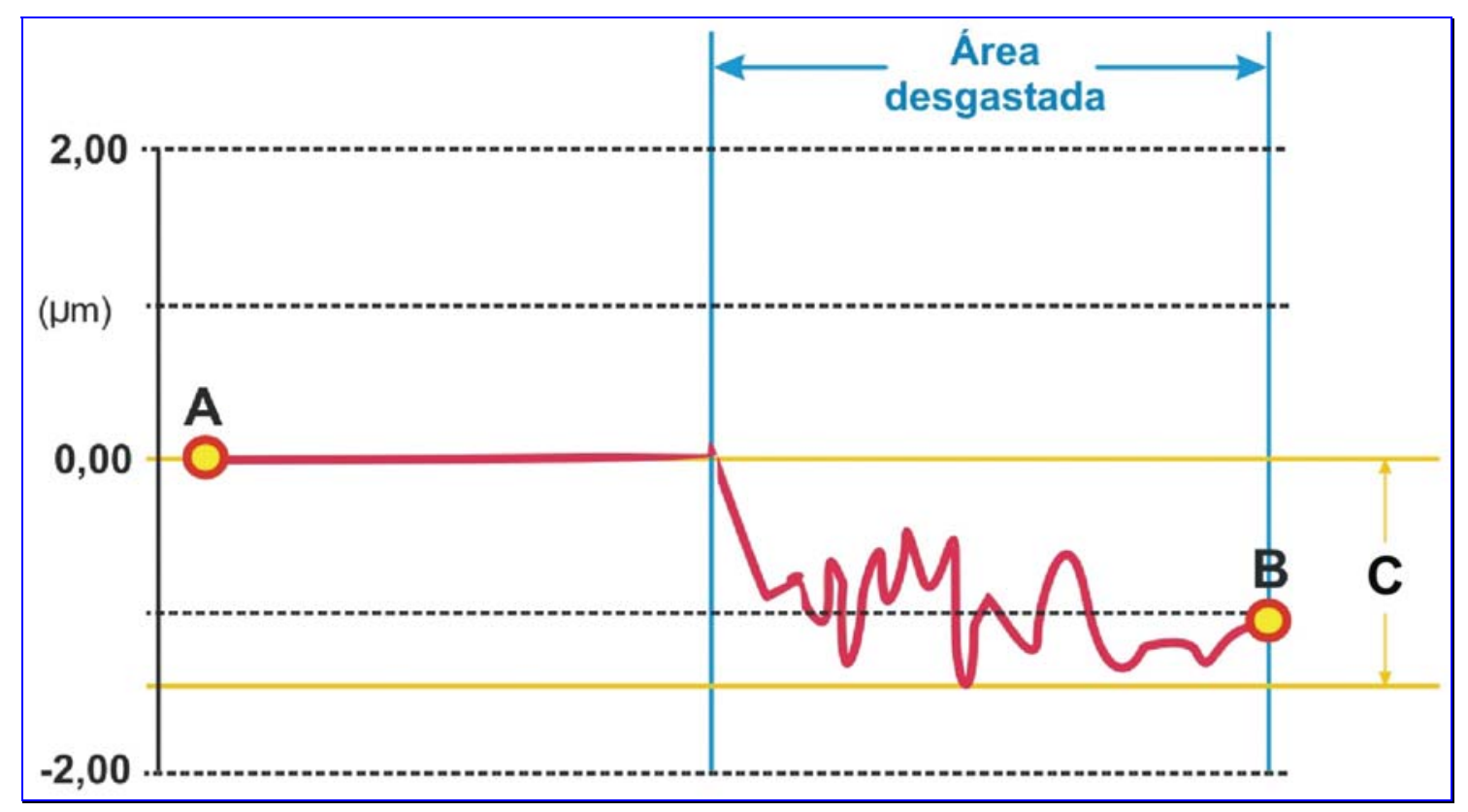

FIGURA 27: Ilustração esquemática mostrando o desgaste dos espécimes testados. (A) início da leitura feita pelo rugosímetro; (B) final da leitura e (C) desgaste máximo ocasionado pelo procedimento de abrasão.

Para aferição do desgaste através do perfil real da superfície de cada copo de prova foram escolhidos os seguintes parâmetros:

$$
\begin{array}{ll}
\text { T mínima }=8 \mu \mathrm{m} & \mathrm{Lt}=10 \mathrm{~mm} \quad \mathrm{Lm}=9 \mathrm{~mm} \\
\mathrm{~T} \text { máxima }=40 \mu \mathrm{m} & \mathrm{Lc}=0.00 \mathrm{~mm} \text { (cut-off) }
\end{array}
$$

Sendo:

T= tolerância (valores extremos a serem considerados nas leituras)

$\mathrm{Lt}=$ limite de tracejamento (extensão real percorrida pela ponta ativa)

Lm= limite de medição (extensão considerada na leitura)

Lc= cut-off (filtragem, minimizando a ondulação da superfície) 


\subsubsection{Forma de Análise Estatística}

Os resultados foram submetidos à analise para a verificação de diferenças ou não entre os grupos, em relação ao desgaste e à alteração de rugosidade superficial. Quando submetidos à ANOVA (análise de variância), foram verificadas diferenças entre os grupos quanto ao desgaste, análise a um critério (técnica) e variações da rugosidade superficial, análise a dois critérios (técnica e fase controle, clareada e escovada). O teste de Tukey $(p<0,05)$ foi aplicado para verificação das diferenças encontradas entre as técnicas de clareamento. 
5. RESULTADO 


\section{RESULTADOS}

\subsection{Rugosidade Superficial}

A análise de variância a dois critérios (técnicas clareadoras e fase de avaliação - controle, clareado e escovado) sobre a alteração de rugosidade superficial não mostrou haver diferença estatisticamente significante entre a rugosidade inicial e após o clareamento. Obedecendo aos mesmos critérios aplicados no procedimento anteriormente citado, verificou-se diferença estatisticamente significante após escovação simulada para os grupos avaliados (Rugosidade Final), onde $\mathrm{F}=380,7$ e $\mathrm{p} \leq 0,05$. Portanto, tornou-se necessária a aplicação do teste de Tukey para comparações individuais entre os grupos.

Seguem-se os valores das médias das leituras registradas pelo rugosímetro Hommel Tester T1000, antes e após os procedimentos de clareamento e de escovação simulada (Tabela 7). Os valores expressos nessa tabela estão didaticamente ilustrados na figura 28.

TABELA 7: Valores das médias de rugosidade aritmética $(\mu \mathrm{m})$, iniciais, após clareamento, após escovação simulada, desvio padrão (DP) e análise estatística dos grupos estudados.

\begin{tabular}{|c|c|c|c|c|c|c|}
\hline & \multicolumn{2}{|c|}{ Rugosidade Inicial } & \multicolumn{2}{|c|}{$\begin{array}{l}\text { Rugosidade Após } \\
\text { clareamento }\end{array}$} & \multicolumn{2}{|c|}{$\begin{array}{l}\text { Rugosidade Após } \\
\text { Escovação }\end{array}$} \\
\hline GRUPOS & Média \pm DP & $\begin{array}{l}\text { Aná. } \\
\text { Estat. }\end{array}$ & Média \pm DP & $\begin{array}{l}\text { Aná. } \\
\text { Estat. }\end{array}$ & Média \pm DP & $\begin{array}{l}\text { Aná. } \\
\text { Estat. }\end{array}$ \\
\hline Controle & $0,1014 \pm 0,0143$ & $\begin{array}{l}\text { A } \\
\mathrm{a}\end{array}$ & - & - & $0,1500 \pm 0,0444$ & $A_{b}$ \\
\hline $\begin{array}{c}\mathrm{PH} 35 \%+ \\
\text { UB }\end{array}$ & $0,1006 \pm 0,0143$ & $\begin{array}{l}\text { A } \\
\mathrm{a}\end{array}$ & $0,0828 \pm 0,0147$ & $\begin{array}{l}\text { A } \\
a\end{array}$ & $0,2834 \pm 0,0573$ & $\begin{array}{l}B \\
b\end{array}$ \\
\hline $\begin{array}{c}\text { PH 35\%+ } \\
\text { Halo. }\end{array}$ & $0,1056 \pm 0,0149$ & $\begin{array}{l}\text { A } \\
a\end{array}$ & $0,1126 \pm 0,0357$ & $B$ & $0,3208 \pm 0,0697$ & $\begin{array}{l}\text { B C } \\
b\end{array}$ \\
\hline PC $16 \%$ & $0,1096 \pm 0,0255$ & $\begin{array}{l}\mathrm{A} \\
\mathrm{a}\end{array}$ & $0,1222 \pm 0,0189$ & $a^{B}$ & $0,3612 \pm 0,0491$ & $b^{C}$ \\
\hline
\end{tabular}

* Letras maiúsculas: análise entre linhas

** Letras minúsculas: análise entre colunas 
FIGURA 28: Gráfico ilustrando as médias dos valores obtidos nos testes de rugosidade.

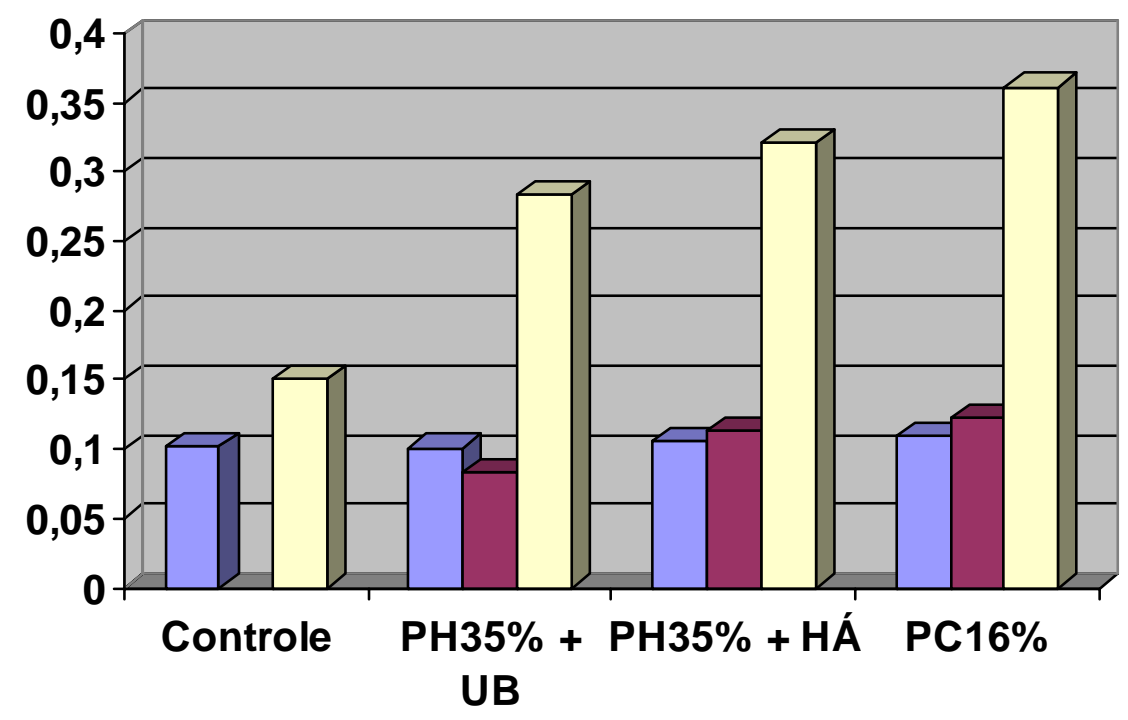

\begin{tabular}{|l|}
\hline Rug. Inicial \\
$\square$ Rug. Clareado \\
$\square$ Rug. Escovado \\
\hline
\end{tabular}

A tabela da análise de variância, aplicados às diferenças dos valores das colunas inicial, após o clareamento e após escovação da tabela 7, para todas as técnicas, são apresentados na tabela 8.

TABELA 8: Resultado da análise de variância para comparação entre as condições. Grupos (grupos estudados) e Fase (fase de tratamento - inicial, clareado e escovado).

\begin{tabular}{c|c|c|c|c|c|c}
\hline GRUPOS & df effect & MS effect & df error & MS error & F & p-level \\
\hline Grupo & $2^{\star}$ & $0,013364^{*}$ & $27^{*}$ & $0,002035^{\star}$ & $6,5670^{\star}$ & $0,004742^{\star}$ \\
\hline Fase & $2^{\star}$ & $0,467571^{*}$ & $54^{\star}$ & $0,001228^{\star}$ & $380,7323^{\star}$ & $0,000000^{\star}$ \\
\hline Interação & 4 & 0,003100 & 54 & 0,001228 & 2,5242 & 0,051343 \\
\hline
\end{tabular}

Levando-se em conta que a análise de variância apontou a existência de diferenças significantes, aplicou-se o teste de Tukey aos citados valores obtidos, cujos resultados podem ser encontrados nas tabelas 9 e 10. 
TABELA 9: Resultado da média das rugosidades e análise estatística para comparação entre os grupos.

\begin{tabular}{c|c|lc}
\hline GRUPOS & Média & \multicolumn{2}{|c}{ Análise } \\
\hline PH 35\% + UB & 0,155600 & A & \\
\hline PH 35\%+ Halo. & 0,179667 & A & B \\
\hline PC 16\% & 0,197667 & & B \\
\hline
\end{tabular}

TABELA 10: Resultado da média das rugosidades e análise estatística para comparação entre as fases analisadas.

\begin{tabular}{c|c|c}
\hline GRUPOS & Média & Análise \\
\hline Rugosidade inicial & 0,105267 & A \\
\hline $\begin{array}{c}\text { Rugosidade após } \\
\text { clareamento }\end{array}$ & 0,105867 & A \\
\hline $\begin{array}{c}\text { Rugosidade após } \\
\text { escovação }\end{array}$ & 0,321800 & B \\
\hline
\end{tabular}

\subsection{Desgaste}

A análise de variância a um critério (técnica clareadora) sobre a variação do desgaste mostrou haver diferença estatisticamente significante entre os grupos testados $(F=29, .45 ; p \leq 0,05)$. Dessa maneira, aplicou-se o teste de Tukey aos citados valores obtidos.

Na tabela 11, são apresentados os valores das médias de desgaste, desvio padrão e análise estatística, após o teste de escovação simulada obtidos em cada condição experimental. Os valores expressos nessa tabela estão didaticamente ilustrados da figura 29.

TABELA 11: Média do desgaste $(\mu \mathrm{m})$, desvio padrão e análise estatística dos diferentes grupos estudados.

\begin{tabular}{c|c|c}
\hline GRUPOS & Média \pm DP & Análise \\
\hline Controle & $9,1710 \pm 1,4644$ & $\mathrm{~A}$ \\
\hline $\mathrm{PH} 35 \%+\mathrm{UB}$ & $12,4942 \pm 1,2550$ & $\mathrm{~B}$ \\
\hline $\mathrm{PH} 35 \%+$ Halo. & $13,7018 \pm 1,0340$ & $\mathrm{~B}$ \\
\hline $\mathrm{PC} 16 \%$ & $13,7487 \pm 1,2239$ & $\mathrm{~B}$ \\
\hline
\end{tabular}


FIGURA 29: Gráfico ilustrando a média do desgaste.

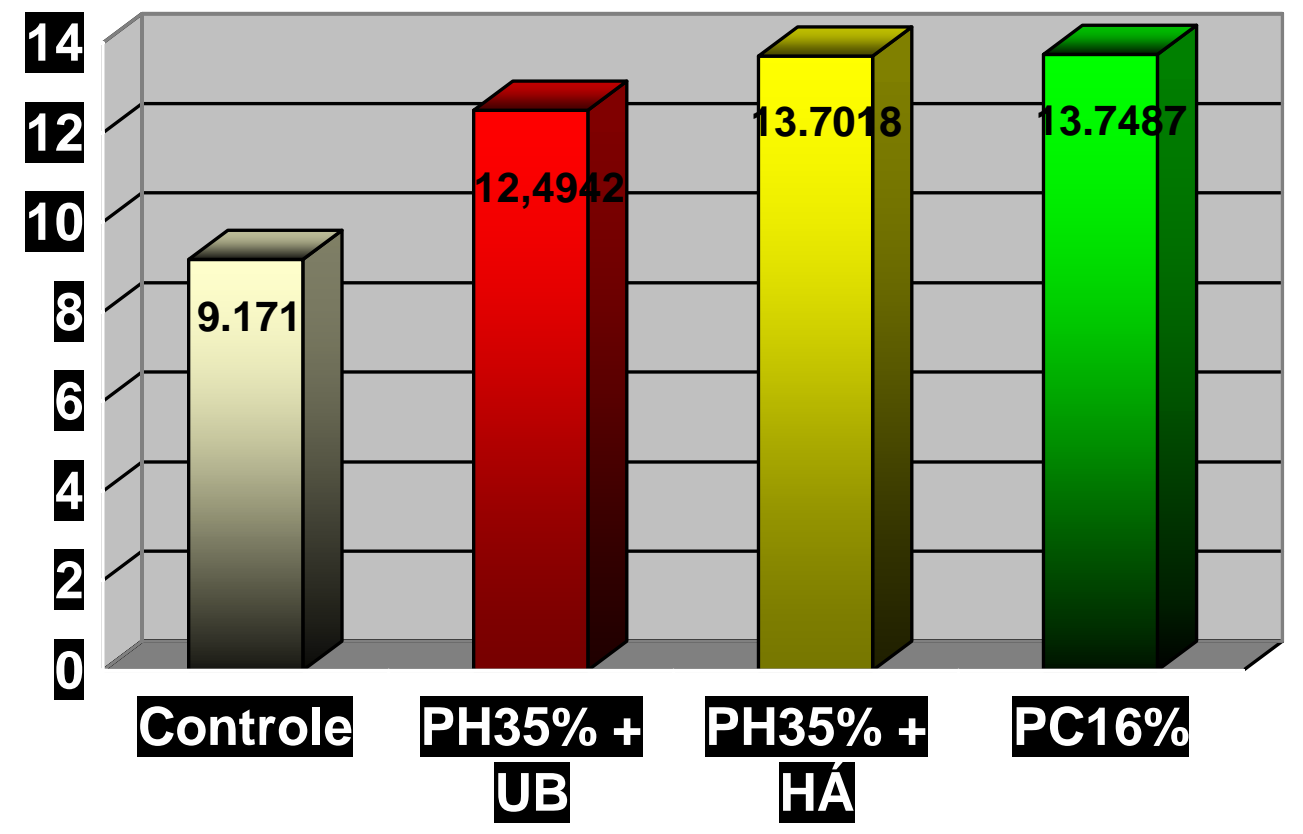


6. DISCUSSÃO

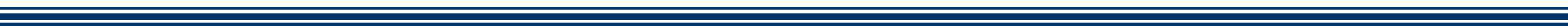




\section{DISCUSSÃO}

\subsection{Discussão Relacionada às Técnicas de Clareamento}

A identificação de uma técnica clareadora que minimizasse alguns dos efeitos colaterais mais significantes passou a ser nosso objetivo de estudo, pois o aumento na rugosidade, mesmo que temporária, poderia levar a um novo ciclo de escurecimento pela deposição de pigmentos, e o desgaste poderia promover perdas significantes de estrutura dentária sadia, principalmente quando da necessidade de novos tratamentos clareadores ao longo da vida dos pacientes.

Várias técnicas já foram propostas para o clareamento dental, todas elas visando a recuperação da harmonia estética do sorriso, evitando um tratamento mais radical. DWINELLE ${ }^{18}$ (1850) utilizou diversos compostos contendo o íon cloro, vapores de enxofre e alguns ácidos, como o oxálico; usou ainda o cloreto de cálcio e de sódio, formando uma pasta destes com o fosfato de cálcio. KINGSBURY ${ }^{46}$ (1861) colocou chumaço de algodão, contendo tintura de iodo, com o objetivo de "neutralizar o material necrótico"; após essa intervenção, aplicou cianeto de potássio na câmara pulpar para remover as manchas provocadas pelo iodo. HARLAN ${ }^{28}$ (1884) lavava a cavidade pulpar com água, ou preferencialmente com peróxido de hidrogênio, depois aplicava cloreto de alumínio hidratado. KIRK $^{47}$ (1889) utilizava uma mistura de sulfito de sódio com ácido bórico. FISCHER ${ }^{20}$ (1910) empregou o peróxido de hidrogênio a 30\% para dentes despolpados e a 15\% para dentes polpados, expondo-os à luz solar. AMES² (1937) utilizou cinco partes de peróxido de hidrogênio a 100\% com uma parte de éter, em volume, a mistura era aquecida por um instrumento. CHRISTENSEN ${ }^{16}$ (1978) realizava o condicionamento do esmalte com ácido fosfórico de 40 a 50\%, por um minuto, e aplicava o peróxido de hidrogênio a 35\% ativado pelo calor.

Um grande impulso, no entanto, em relação às técnicas para o clareamento dental, ocorreu no final do século XX e início deste século. Inicialmente houve a divulgação da técnica caseira, em 1989, onde HAYWOOD; HEYMANN ${ }^{32}$ preconizou o uso do peróxido de carbamida a 10\% em moldeira por um período de 6 a 8 horas 
diárias, durante 2 a 5 semanas. Posteriormente o ressurgimento do clareamento de consultório utilizando agentes clareadores em alta concentração e ativados por fonte de luz ou calor ou uma combinação das duas. LORENZO et al. ${ }^{53}$ (1996) ativou o agente clareador com luz halógena por 4 minutos. No mesmo ano, o Ion Laser Technology (ILT) aprovou o emprego do laser de argônio e $\mathrm{CO}_{2}$, onde a rápida absorção da energia laser aquece a solução e não a estrutura dentária (REYTO ${ }^{69}$, 1998; KUTSCH $\left.{ }^{48}, 1993\right)$. GARBER ${ }^{22}$ (1997), utilizou como fontes catalisadoras, os laseres de argônio e $\mathrm{CO}_{2}$ ou uma combinação dos dois, com intuito de acelerar o processo clareador. MONDELLI ${ }^{61}$ (1998), empregou espátulas ou brunidores aquecidos. A ADA (1998), relatou que o uso do laser de argônio no lugar de luz halógena pode ser aceitável, se os procedimentos forem rigorosamente obedecidos. RIEHL (2000) usou lâmpada incandescente. MONDELLI ${ }^{62}$ (2003) utilizou luz híbrida, composta por LED e laser de diodo, para ativação. SULIEMAN et al. ${ }^{79}$ (2004) empregou lâmpada de arco de plasma.

Este estudo avaliou três técnicas clareadoras usuais na prática odontológica: uma caseira, utilizando o peróxido de carbamida a 16\% por um período de 2 horas diárias, durante 14 dias, e duas de consultório utilizando o peróxido de hidrogênio a 35\% fotossensível ativado por luz halógena e por luz híbrida (LED e Laser de Diodo).

A reação de clareamento das estruturas dentais ainda não está completamente esclarecida. Sabe-se que o esmalte comporta-se como uma membrana semipermeável, possibilitando o trânsito de água e substâncias de pequeno peso molecular, como por exemplo, os peróxidos de carbamida e de hidrogênio, por entre seus poros (BOWLES; UGWUNERI ${ }^{11}$, 1987; HANKS et al. ${ }^{27}$, 1993; HAYWOOD et al. ${ }^{33}$, 1990; HAYWOOD ${ }^{36}$, 1997; McEVOY ${ }^{56}$, 1989; SPALDING ${ }^{77}$, 2000). No entanto, a capacidade de difusão depende de vários fatores, como a composição do agente penetrante, a natureza do tecido dental, a área da superfície exposta e sua localização, a presença da "smear layer", o tempo de exposição e a temperatura (BOWLES; UGWUNERI ${ }^{11}$, 1987; ROTSTEIN; TOREK; LEWINSTEIN $^{72}$, 1991).

Porém alguns inconvenientes podem estar associados à utilização do calor. PASHLEY; THOMPSON; STEWART ${ }^{65}$ (1983), relatou que o aumento de $40^{\circ} \mathrm{C}$ quase 
dobra o fluxo dos fluidos através da dentina. BOWLES; UGWUNERI ${ }^{11}$ (1987), observaram maior difusão das substâncias. RODSTEIN; TOREK; LEWINSTEIN ${ }^{72}$ (1991), demonstraram que o aumento da temperatura pode ser prejudicial quando se prolongam por muito tempo as sessões de clareamento. Recomendaram que o uso do calor e a duração das sessões fossem diminuídos.

\subsection{Discussão Relacionada aos Métodos Empregados}

Para este estudo foram selecionados incisivos inferiores bovinos devido à semelhança estrutural e histológica destes com os dentes humanos (ANDERSON, LIVINKIND; ARENDS; SCHUTHOF; JONGEBLOED ${ }^{4}$, 1980; ELLIOTT³, 1998; GIOIA $^{23}$, 2000; KWON et al. ${ }^{49}$, 2002; MANNING; EDGAR ${ }^{54}$, 1992; MENEZES; FIROOZMAND; HUHTALA ${ }^{59}$, 2003; SATO et al. ${ }^{73}$, 1999), serem de fácil coleta, conseguidos em grandes quantidades, e por possuírem volume vestibular suficiente, proporcionando uma área "plana" extensa para o propósito do estudo (MELLBERG ${ }^{58}$, 1992; PIMENTA et al. ${ }^{66}$, 2003; RIHEL ${ }^{70}$, 2002).

Outra característica vantajosa desse substrato é a sua homogeneidade, mostrando-se algumas vezes com uma variabilidade biológica menor do que o esmalte humano (MANNING; EDGAR ${ }^{54}$, 1992; MELLBERG ${ }^{58}, 1992$ ), uma vez que não estão expostos a altas concentrações de flúor e não sofrem desafios cariogênicos (MELLBERG ${ }^{58}$, 1992).

Essas características foram confirmadas neste estudo, uma vez que o esmalte bovino demonstrou baixos valores de desvio-padrão, tanto para os testes de rugosidade como para os de desgaste superficial. A análise estatística dos resultados mostrou diferença significante entre as várias correlações propostas, comprovando que, mesmo com uma amostra relativamente pequena por grupo, pode-se obter diferença estatisticamente significativa entre eles em função da pequena variabilidade apresentada pelo substrato bovino.

Durante o preparo dos espécimes, foi necessária uma planificação da superfície vestibular do esmalte bovino exposto, pois essa superfície apresenta-se extremamente irregular e rugosa, com numerosas e profundas periquimáceas, o que impossibilitaria o adequado registro numérico do desgaste e da rugosidade com o 
seu respectivo dispositivo de leitura. Após a regularização do esmalte, com lixas de granulação decrescente, obteve-se uma maior uniformidade entre todos os quarenta corpos-de-prova.

As medições de rugosidade superficial foram realizadas através do rugosímetro Hommel Tester T1000 - Hommelwerke $\mathrm{GmbH}$. O padrão de leitura utilizado foi à rugosidade aritmética $(\mathrm{Ra})$ ou ainda, roughness average. A média aritmética entre os picos e vales percorridos pelo instrumento. Para cada superfície do corpo-de-prova foram realizadas cinco leituras aleatórias. TURSSI ${ }^{81}, 2001$; PIMENTA, et al. ${ }^{66}$, 2003 e RIEHL ${ }^{70}$, 2002, adotaram a realização de três leituras de rugosidade por corpo-de-prova. Em 2003, WORSCHECH et al. ${ }^{82}$, adotaram seis leituras. No presente trabalho, por se tratar de um numero estatisticamente suficiente, adotou-se realizar cinco leituras (ASENJO-MARTINEZ ${ }^{5}$, 2004; HOSOYA et al. ${ }^{40}, 2003$; RIOS et al. $\left.{ }^{71}, 2002\right)$.

O Lase Peroxide (DMC Equipamentos) contém em sua composição corantes a base de Juá e Urucum, agentes fotossensíveis, o que justifica a cor avermelhada. Os grupos tratados por tal produto precisam ser irradiados por uma fonte de luz, com o intuito de sensibilizar o agente clareador (GARBER, 199722. GOLDSTEIN ${ }^{24}, 1997$; KUTSCH $^{48}$, 1993; MONDELLI ${ }^{62}$, 2003; REYTO ${ }^{69}$, 1998; RIHEL ${ }^{70}$, 2002; ZANIN ${ }^{84}$, 2003), acelerando o processo de clareamento pelo aumento da liberação do oxigênio nascente, que é o íon responsável pelo efeito clareador.

O grupo clareado com peróxido de hidrogênio a 35\% fotossensível (Lase Peroxide, DMC Equipamentos), ativado por luz híbrida (LED e laser de diodo) Sistema Laser Ultrablue IV (DMC Equipamentos), promoveu a decomposição da molécula de peróxido, como se referiu REYTO ${ }^{69}$, em 1998. MONDELLI ${ }^{62}$, 2003 e ZANIN $^{84}$, no mesmo ano, explicam que esta decomposição se dá parte pela luminosidade e parte pelo aquecimento, gerado pelo laser de diodo, uma vez que, o LED é composto por luz fria

O outro grupo foi clareado com o mesmo agente clareador, porém ativado com luz halógena Curing Light 2500 (3M/ESPE, Dental Products), sendo esta uma fonte geradora de calor $\left(\right.$ GIOIA $^{23}, 2000$; GOLDSTEIN ${ }^{24}, 1997$; GULTZ et al. ${ }^{26}$, 1999; LORENZO et al. ${ }^{53}$, 1996; McGUCKIN; BABIN; MAYER ${ }^{57}$, 1992). 
Um terceiro grupo empregou o Witheness Perfect, um agente clareador à base de peróxido de carbamida à 16\%. A maioria dos trabalhos consultados neste estudo empregou o peróxido de carbamida puro (BEM-AMAR et al. ${ }^{9}$, 1995; CIMILLI; PAMEIJER ${ }^{15}$, 2001; CONVIGTON et al. ${ }^{17}$, 1990; HEYWOOD; HEYMANN ${ }^{32}$, 1989; HEYWOOD; HOUCK; HEYMANN ${ }^{34}$, 1991; KALLILI et al. ${ }^{45}$, 1991; MCCRACKEN; HAYWOOD ${ }^{55}$, 1995; MENEZES, FIROOZMAND, HUHTALA ${ }^{59}$, 2003; MONDELLI ${ }^{62}$, 2003), sem nenhum método de ativação que permitisse sua adequada decomposição, muito embora outros estudos salientassem a importância da saliva artificial como componente de ativação (HAYWOOD et al. ${ }^{33}$, 1990; HOSOYA et al. ${ }^{40}$, 2003; PINHEIRO JUNIOR et al. ${ }^{67}$, 1996; SPALDING ${ }^{77}$, 2000), funcionando como um iniciador para a decomposição do peróxido de carbamida em uréia e peróxido de hidrogênio e, este último, em oxigênio nascente e água. Neste estudo, foi utilizada a saliva artificial, como gatilho, durante o clareamento.

Nos intervalos entre as sessões de clareamento de todos os grupos, os espécimes ficaram armazenados em saliva artificial, especificamente formulada para a remineralização, (JOSEY et al. ${ }^{43}$, 1996; JUNQUEIRA et al. ${ }^{44}$, 2000; LEONARD JR.; BENTLEY; HAYWOOD ${ }^{51}$, 1994; SERRA; CURY ${ }^{74}$, 1992; WORSCHECH et al. ${ }^{82}$, 2003), diminuindo a erosão superficial, mais uma vez valorizando o que ocorre realmente durante um tratamento clareador completo na cavidade bucal.

O tempo de aplicação do peróxido de carbamida é um fator importante a ser analisado, uma vez que, no trabalho pioneiro de HAYWOOD; HEYMANN ${ }^{32}$, em 1989, era preconizado que o peróxido permanecesse pelo tempo de 8 a 12 horas diárias, de preferência à noite, durante 2 a 5 semanas (BEM-AMAR et al. ${ }^{9}, 1995$; HUNSAKER; CHRISTENSEN; CHRISTENSEN ${ }^{41}$, 1990; McGUCKIN; BABIN; MAYER ${ }^{57}$, 1992; SHANNON et al. ${ }^{76}$, 1993). Estudos mais recentes indicam uma posologia mais branda, com um tempo de 4 a 6 horas diárias, por um período de 1 a 3 semanas, sendo desejável, inclusive, que se empregue a moldeira durante 0 período diurno (LEE et al. ${ }^{50}$, 1995; McCRACKEN; HAYWOOD ${ }^{55}$, 1996; RIHEL $^{70}$, 2002; SPALDING ${ }^{77}$, 2000). Este estudo utilizou o peróxido de carbamida durante 2 horas diárias, por 2 semanas.

O equipamento simulador de escovação é dotado de um sensor de temperatura que viabiliza a escovação a $37^{\circ} \pm 2^{\circ} \mathrm{C}$ através de um monitoramento 
preciso e livre de interferências externas. A importância do monitoramento da temperatura é explicada por HARTE; MANLY ${ }^{30}$ (1975). Segundo esses autores, testes realizados a $37^{\circ} \mathrm{C}$, são $28 \%$ menos abrasivos em comparação aos realizados a temperatura ambiente e em temperaturas muito elevadas a rigidez das cerdas das escovas dentais diminui.

A amplitude da excursão dos movimentos de escovação varia, na literatura, de 15mm (ASHMORE; VAN ABBE; WILSON ${ }^{6}, 1972 ;$ HEATH; WILSON $^{37}$, 1976) e 85mm (REDMALM; RYDÉN ${ }^{68}$, 1979). A influência entre o comprimento do movimento da escova dental com o desgaste é explicada por HEATH; WILSON ${ }^{37}$ (1976), os quais, quando utilizaram o comprimento de $45 \mathrm{~mm}$ associado a um dentifrício, constataram que o desgaste foi significantemente maior em relação ao comprimento de $15 \mathrm{~mm}$. Por outro lado, na ausência de dentifrício o desgaste foi menor para o comprimento de $45 \mathrm{~mm}$ em relação ao de $15 \mathrm{~mm}$. Ainda em percursos de 15mm, o desgaste foi igual quando o teste foi ou não associado ao dentifrício, isso porque excursões maiores fazem diminuir o contato entre as cerdas e o espécime e excursões menores desgastam os espécimes por ruptura de partículas. A excursão dos movimentos de escovação, para o presente estudo, foi ajustada em 20mm, por se tratar de uma amplitude próxima da condição oral (TURSSI ${ }^{81}, 2001$; ANSEJO-MARTINEZ $\left.{ }^{5}, 2004\right)$.

A carga aplicada sobre os espécimes durante a escovação também pode exercer forte influência sobre o desgaste, essa correlação é constatada no trabalho realizado por STOOKEY; MUHLER ${ }^{78}$, em 1968. Os autores submeteram esmalte e dentina a teste de escovação simulada com o aumento progressivo da carga exercida pela escova, variando de 75 a $300 \mathrm{~g}$, e obtiveram aumento progressivo do desgaste para os dois substratos. Esses dados vêm ao encontro daqueles obtidos por HEATH; WILSON ${ }^{37}$ (1976), os quais sugerem que o aumento da carga de escovação leva a uma maior perda de material, e que existe um limite de carga até o qual a escova irá exercer a sua função adequadamente, $7 \mathrm{~N}$ acima desse valor promoverá um declive dos valores de desgaste, provavelmente devido ao "envergamento" das cerdas. O que se nota na literatura é uma margem grande do valor de carga utilizada, variando de $75 \mathrm{~g}$ (STOOKEY; MUHLER ${ }^{78}, 1968$ ), $200 \mathrm{~g}$ (RIOS et al. ${ }^{71}$, 2002; SULIEMAN et al. ${ }^{79}, 2004$; WORSCHECH et al. ${ }^{82}, 2003$ ) a $700 \mathrm{~g}$ 
(|HEATH; WILSON ${ }^{37}$, 1976). TURSSI ${ }^{81}$, 2001, e ASENJO-MARTINEZ ${ }^{5}, 2004$, utilizaram $300 \mathrm{~g}$, sendo este último o valor adotado para o presente estudo, uma vez que foram empregadas máquinas de escovação semelhantes.

A suspensão utilizada nos testes do presente trabalho foi constituída de dentifrício (Colgate MFP) e água destilada deionizada (ANSEJO-MARTINEZ ${ }^{5}, 2004$; MOTTA et al. ${ }^{63}$, 1998; RIOS et al. $^{71}$, 2003; TURSSI $^{81}$, 2001) na proporção de 1:2 em peso (ISSO/TS 14569-1), sendo este dentifrício considerado de média abrasividade por BASTOS ${ }^{8}$, em 1985.

Uma das grandes discussões sobre os testes in vitro utilizando escovação simulada refere-se a sua "equivalência" cronológica in vivo. De acordo com SEXSON; PHILLIPS ${ }^{75}$ (1951), a cada escovação o paciente costuma realizar 15 ciclos em uma determinada região. HEATH; WILSON ${ }^{37}$ (1976) testaram a resistência ao desgaste de uma série de materiais, entre eles, o ouro, amálgama e resinas quimicamente ativadas, e consideraram o maior percentual de desgaste obtido pela resina sem carga calculando que levaria cerca de 1750 anos para se abrasionar $1 \mathrm{~mm}$ de esmalte na cavidade oral. Os autores ignoraram outras influências, dentre elas a mastigação, concluindo que 20.000 ciclos de escovação simulada equivaleriam a aproximadamente 10 meses in vivo. Para HARRINGTON et al. ${ }^{29}$, em 1982, 240.000 ciclos equivalem a 4 anos de escovação. A correlação mais aceitável parece ser a estabelecida por BUCHALLA; ATTIN; HELLWIG ${ }^{12}$, em 2000, onde um paciente costuma realizar em média 4,5 ciclos de escovação por segundo, supondo que cada sextante é escovado por cerca de 20 segundos, 90 ciclos serão realizados até o término do procedimento, de forma que 6.000 ciclos de escovação teriam a equivalência de 1 a 2 meses na cavidade oral. No presente estudo, o esmalte bovino foi submetido a 100.000 ciclos de escovação simulada, equivalendo aproximadamente a 2 anos de escovação in vivo.

As primeiras investigações e preocupações em relação ao desgaste dentário são atribuídas a MILLER ${ }^{60}$ (1907) que considerou os diversos fatores capazes de produzir esse desgaste, como a erosão, abrasão, atrição, levando à exposição dentária. O autor enfatizou a avaliação de ocorrências de desgastes por abrasão nos elementos dentários submetidos à escovação. Segundo GRANBSTETTER et al. ${ }^{25}$, em 1958, o método da marcação radioativa para a quantificação da perda estrutural 
de espécimes submetidos aos testes de desgaste é mais rápido e preciso que os outros métodos empregadas. HEFFERREN ${ }^{38}$ (1976) afirmou que o método baseado na perda de peso não é recomendado para os tecidos dentários, uma vez que leva a resultados falhos. O melhor método seria a contagem radioativa do material desgastado. BARBAKOW; LUTZ; IMFELD ${ }^{7}$ (1987) afirmaram que a marcação radioativa e a perfilometria superficial são os métodos mais largamente utilizados para avaliar o desgaste dental, entretanto estes também podem ser feitos através da perda de massa. RIOS et al. $^{71}$ (2002) determinaram o desgaste por meio da quantidade de massa perdida, mensurada por uma balança eletrônica. MENEZES; FIROOZMAND; HUHTALA ${ }^{59}$ (2003), estudaram a perda superficial do esmalte após clareamento, através de uma máquina de ensaio de medição tridimensional.

Para mensuração do desgaste, foi utilizado neste trabalho a perfilometria por meio do rugosímetro que, através de sua pequena ponta apalpadora, percorre toda a superfície a ser testada, traçando o seu perfil (CARPINETTI et al. ${ }^{13}$, 1996; HONÓRIO 39 2003; ARSENJO-MARTINEZ ${ }^{5}$, 2004). Em função de sua rugosidade natural, o perfil do esmalte bovino hígido apresenta-se com um desenho extremamente variável e irregular e, caso o tratamento clareador e a escovação simulada fossem realizados sobre essa superfície, dificilmente o perfil após o tratamento permitiria a visualização da perda estrutural resultante dos tratamentos empregados. Assim sendo, após a regularização da superfície com o polimento, o perfil se apresentou como uma linha reta, ou seja, qualquer variação encontrada após o clareamento e escovação simulada seria resultado do tratamento realizado.

Essa evidência do desgaste resultante do tratamento executado fica ainda mais visível em função da forma como foram feitos os procedimentos de clareamento e escovação simulada, pois foi utilizada uma fita adesiva protegendo metade do corpo-de-prova, da ação do agente clareador e uma base metálica que protegia esta porção da ação da escova dental, ou seja, o desgaste não ocorreu sobre toda a superfície do fragmento, apenas sobre a área exposta (ANSEJOMARTINEZ ${ }^{5}$, 2004; HONÓRIO ${ }^{39}$, 2003; MENEZES; FIROOZMAND; HUHTALA ${ }^{59}$, 2003).

Dessa forma, quando a ponta apalpadora do rugosímetro percorreu a superfície do espécime após o tratamento, ela teve contado inicialmente com o lado 
controle, superfícies não desgastadas e depois, com o lado teste, submetidos aos tratamentos de clareamento e escovação simulada, o que resultou num perfil semelhante a uma linha reta no lado controle. qualquer variação encontrada após o clareamento e escovação, seria resultado do tratamento clareador.

O protocolo empregado neste estudo teve como objetivo simular tratamentos clareadores completos, que ocorrem na cavidade oral, quanto à concentração do agente clareador, a técnica de utilização desses agentes, a escovação e a imersão em solução remineralizadora de saliva artificial.

\subsection{Discussão Relacionada aos Resultados Encontrados}

Os resultados da presente pesquisa indicaram haver influência das diferentes técnicas clareadoras no desgaste e na rugosidade superficial do esmalte bovino após escovação simulada.

Ao avaliar os testes de rugosidade superficial, observou-se que nenhuma das três técnicas clareadoras empregadas promoveram alterações estatisticamente significantes na superfície do esmalte após o tratamento clareador, comparando com a rugosidade inicial, como podem atestar as tabelas referentes à média, à análise de variância e o teste de Tukey. Esse resultado está de acordo com os achados de alguns autores, como ERNEST; MARROQUIN; ZONNCHEN ${ }^{19}$, 1996; HAYWOOD et al. $^{33}$, 1990, HAYWOOD; HOUCK; HEYMANN ${ }^{34}$, 1991, HUNSAKER; CHRISTENSEN; CHRISTENSEN $^{41}$, 1990; SPALDING ${ }^{77}$, 2000; SULIEMAN et al. $^{79}$, 2004 e WORSCHECH et al. $^{82}$, 2003. Os quais afirmaram a ausência de alterações na textura superficial do esmalte dentário quando submetido ao tratamento com agentes clareadores. GULTZ et al. $^{26}$ (1999) verificaram, através da microscopia eletrônica de varredura, que agentes clareadores fotossensíveis, de alta concentração e de uso em consultório, não causaram mudanças significativas na superfície do esmalte. SULIEMAN et al. $^{79}$ (2004) estudaram os efeitos do clareamento com peróxido de hidrogênio sobre a integridade do esmalte e da dentina, concluindo que a utilização de agentes em alta concentração não causam efeitos deletérios ao esmalte e à dentina. 
Porém, outros autores relatam os efeitos dos agentes clareadores na estrutura dentária, mostrando que eles podem alterar a microdureza do esmalte (CIMILLI; PAMEIJER, 2001 ${ }^{15}$; PINHEIRO JR. et al. ${ }^{67}$, 1997; RIEHL ${ }^{70}$, 2002), a composição química (CIMILLI; PAMEIJER ${ }^{15}$, 2001; ERNEST; MARROQUIN; ZONNCHEN $^{19}$, 1996), a força de adesão dos sistemas adesivos e resinas compostas ao esmalte recém clareado (BEM-AMAR et al. ${ }^{9}, 1995$; JOSEY et al. ${ }^{43}$, 1996), o desgaste e a rugosidade superficial (HAYWOOD; HOUCK; HEYMANN ${ }^{34}$, 1991; HOSOYA et al. ${ }^{40}$, 2003; JOSEY et al. ${ }^{43}$, 1996; JUNQUEIRA et al. $^{44}$, 2000; LEE et al. ${ }^{50}$, 1995; PIMENTA et al. ${ }^{66}$ 2003; RIEHL ${ }^{70}, 2002$; TITLEY; TORNECK; SMITH ${ }^{80}$, 1988).

Ao comparar, neste estudo, os valores de rugosidade superficial dos diferentes grupos; após a escovação simulada, com a rugosidade superficial inicial e após o clareamento, verificou-se que o procedimento abrasivo aumenta a rugosidade de todos os grupos, inclusive a do grupo controle que não recebeu nenhum tratamento clareador. Porém os grupos que receberam tratamento clareador apresentaram uma diferença estatística maior no valor da rugosidade que o grupo controle. Os resultados estão de acordo com os achados na literatura, onde o clareamento torna a superfície do esmalte mais susceptível ao processo de abrasão (JOSEY et al. ${ }^{43}, 1996$; KALILI ${ }^{45}$ et al., 1991; WORSCHECH et al. ${ }^{82}$, 2003).

O grupo clareado com peróxido de carbamida a 16\%, apresentou os maiores valores de rugosidade. O grupo clareado com peróxido de hidrogênio a 35\% ativado por fonte de luz halógena (Curing Light 2500-3M/ESPE, Dental Products) não mostrou diferença estatística em relação aos outros dois grupos, e o grupo clareado com peróxido de hidrogênio a 35\%, ativado por fonte de luz híbrida (LED e laser de diodo, Ultrablue IV - DMC Equipamentos), apresentou valores de rugosidade estatisticamente menores. Esses resultados vão de encontro com alguns autores, como LEE et al. ${ }^{50}$, 1995; McGUCKIN; BABIN; MAYER ${ }^{57}, 1992$; RIEHL ${ }^{70}, 2002$; ZALKIND et al. ${ }^{83}$, 1996, os quais encontraram valores maiores de rugosidade superficial para os grupos tratados com agentes clareadores de alta concentração. No entanto outros autores localizaram alterações morfológicas significantes no esmalte após clareamento com peróxido de carbamida em baixa concentração, como porosidades, crateras, erosões e irregularidades (BEM-AMAR et al. ${ }^{9}, 1995$; 
BITTER $^{10}$, 1992; CONVINGTON et al. ${ }^{17}$, 1990; SHANNON et al. ${ }^{76}$, 1993). Isso sugere que o maior tempo de contato do agente clareador na superfície do esmalte, o que ocorre com as técnicas de clareamento caseiro (HAYWOOD; HEYMANN ${ }^{32}$, 1989), torna o esmalte mais susceptível a alterações morfológicas. Por outro lado, as técnicas que utilizam agentes clareadores em alta concentração ativados por uma fonte de luz ou calor, acelera a decomposição do peróxido (CHEN; XU; SHING ${ }^{14}$, 1993; LORENZO et al. ${ }^{53}$, 1996; REYTO ${ }^{69}$, 1998; MONDELLI ${ }^{62}$, 2003), levando ao clareando em um menor tempo.

A ativação com os sistemas à base de laser e LED demonstraram melhores resultados provavelmente devido à decomposição do peróxido ocorrer parte pela luminosidade e parte pelo aquecimento, gerado pelo laser de diodo, uma vez que, o LED é composto por luz fria (KUTSCH${ }^{48}$, 1993; GOLDSTEIN ${ }^{24}$, 1997). Assim ocorrem emissões fotônicas, não ionizantes e concentradas que ao interagir com os tecidos produzem efeitos fotoquimícos e mínimo efeito fototérmico, pois tem como alvo moléculas escurecidas, as quais são excitadas absorvendo a energia do laser, potencializando o processo de clareamento. Gerando mínimo aumento de temperatura, uma vez que aquece o agente clareador e não a estrutura dental, fazendo com que a decomposição e a penetração do peróxido seja menor do que quando do uso do calor (KUTSCH ${ }^{48}$, 1993; GABER ${ }^{22}, 1997$; REYTO ${ }^{69}$, 1998; GIOIA $^{23}$, 2000; MONDELLI ${ }^{62}$, 2003; ZANIN ${ }^{84}$, 2003). O aumento de temperatura, entretanto, que ocorre com a luz halógena aumenta a permeabilidade do esmalte, possivelmente levando a estrutura dentária a sofrer mais diretamente os efeitos do agente clareador (CHEN; XU; SHING ${ }^{14}$, 1993; LORENZO et al. ${ }^{53}$, 1996; ROTSTEIN; TOREK; LEWINSTEIN $\left.{ }^{72}, 1991\right)$.

Alguns trabalhos verificaram o efeito dos agentes clareadores na composição do esmalte. CONVINGTON et al. ${ }^{17}$ (1990) verificaram perda de componentes orgânicos nas superfícies dos grupos tratados com peróxido de carbamida por, 4 horas, durante três semanas. McCRACKEN; HAYWOOD ${ }^{55}$ (1996) constataram perda de cálcio no esmalte quando exposto ao peróxido de carbamida a 10\%, por 6 horas. JOSEY et al. ${ }^{43}$ (1996), observaram através da microscopia ótica perda de mineral na superfície de esmalte clareado com peróxido de carbamida e escovado, concluindo que o clareamento altera as camadas superficiais e subsuperficiais do 
esmalte. MENEZES; FIROOZMAND; HUHTALA ${ }^{59}$ (2003), observaram que, após clareamento com peróxido de carbamida e escovação, há uma perda superficial clinicamente significante do esmalte a depender da abrasividade do dentifrício. $\mathrm{O}$ presente estudo avaliou quantitativamente o desgaste superficial do esmalte, utilizando três diferentes técnicas de clareamento após escovação simulada.

O esmalte bovino apresenta uma superfície extremamente irregular e rugosa, e os trabalhos referentes ao desgaste em esmalte humano ou bovino apresentam perdas estruturais infinitamente menores que as próprias irregularidades da superfície do esmalte dental bovino (RIEHL ${ }^{70}$, 2002; HONÓRIO ${ }^{39}$, 2003; STOOKEY; MUHLER $^{78}$, 1968). SULIEMAN et al. $^{79}$, em 2004, após simularem tratamento clareador em esmalte humano, verificaram um desgaste de 0,08 $\mu \mathrm{m}$ na superfície dental. Assim sendo, sabendo que os desgastes encontrados seriam microscópicos e que as irregularidades da superfície do substrato a ser testado são macroscópicas, o seu polimento permitiu a visualização exata da área desgastada através da metodologia empregada para a quantificação da perda estrutural.

Os resultados demonstram que 100.000 ciclos de escovação simulada levam ao desgaste da estrutura dentária, sendo este maior nos grupos que receberam tratamento com agente clareador: peróxido de hidrogênio a 35\% ativado com luz híbrida (LED e Lazer de Diodo) desgastou 12,4 $\mu \mathrm{m}$; peróxido de hidrogênio a 35\% ativado com luz halógena $13,7 \mu$ m e peróxido de carbamida a 16\% 13,7 $\mu \mathrm{m}$, quando comparado ao grupo controle que recebeu apenas escovação simulada e desgastou 9,1 $\mu \mathrm{m}$. Entre as diferentes técnicas clareadoras, não houve diferença estatística no desgaste superficial do esmalte. Os resultados deste estudo estão de acordo com a literatura, onde o processo de abrasão leva à perda de estrutura dentária (GRABENSTETTER et al. ${ }^{25}$, 1958; MENEZES; FIROOZMAND; HUHTALA ${ }^{59}$, 2003; RELDMALN; RYDÉN ${ }^{68}$, 1979; STOOKEY; MUHLER $\left.{ }^{78}, 1968\right)$, e que quando associado ao tratamento clareador, esta se torna maior (JOSEY et al. ${ }^{43}$, 1996; KALILI et al. ${ }^{45}$, 1991; WORSCHECH et al. ${ }^{82}$, 2003). Levando-se em consideração que 100.000 ciclos de escovação simulada equivalem, em média, a 2 anos de escovação in vivo, como já foi discutido, um desgaste entre 12 e $13 \mu \mathrm{m}$ não seria clinicamente significante, uma vez que outros fatores concorrem para a 
7. CONCLUSÕES 


\section{CONCLUSÕES}

- Após o clareamento, nenhuma das técnicas utilizadas alterou de forma significante a rugosidade superficial do esmalte bovino.

- O peróxido de carbamida a 16\%, após escovação simulada, determinou a maior alteração superficial de rugosidade, enquanto o peróxido de hidrogênio, a 35\%, ativado pela fonte de luz híbrida (LED e Laser de Diodo - Ultrablue IV) proporcionou a menor alteração.

- As técnicas de clareamento empregadas proporcionaram desgaste semelhante do esmalte bovino após escovação simulada.

- O clareamento leva a superfície do esmalte a uma maior susceptibilidade, ao aumento de rugosidade e desgaste superficial, quando submetido á escovação simulada. 
REFERÊNCIA BIBLIOGRÁFICA 


\section{Referências Bibliográficas}

1. AMERICAN DENTAL ASSOCIATION. Council on Scientific Affairs. Laser assisted bleaching: an update. J Amer Dent Assoc, v.129, n.10, p.14847, Oct. 1998.

2. AMES, J.W. Removing stains from mottled enamel. J Amer Dent Assoc I Dent Cosmos, p. 1674-7, Oct. 1937.

3. ANDERSON, P.; LIVINKIND, M.; ELLIOTT, J.C. Scanning microradiographic studies of rates of in vitro demineralization in human and bovine dental enamel. Arch Oral Biol, v.43, n.8, p.649-56, Aug. 1998.

4. ARENDS, J.; SCHUTHOF, J.; JONGEBLOED, W.G. Lesion depth and microhardness indentations on artificial white spot lesions. Caries Res, v.14, n.4, p.190-5, 1980.

5. ASENJO-MARTINEZ, M.A.J. Avaliação do desgaste e da rugosidade superficial de uma resina composta, após escovação simulada, em função de diferentes energias e fontes de luz usadas na polimerização. Bauru, 2004. 149p. Dissertação (Mestrado) - Faculdade de Odontologia de Bauru, Universidade de São Paulo.

6. ASHMORE, H.; VAN ABEE, N.J.; WILSON, S.J. The measurement in vitro of dentine abrasion by toothpaste. Brit Dent J, v.133, n.2, p.60-6, July 1972.

7. BARBAKOW, F.; LUTZ, F.; IMFELD, T. Relative dentin abrasion by dentifrices and prophylaxis pastes: implications for clinicians, manufacturers and patients. Quintessence Int, v.18, n.1, p.29-34, Jan. 1987.

*Normas recomendadas para uso no âmbito da Universidade de São Paulo, com base no documento "Referências Bibliograficas: exemplo", emanado do Conselho Superior do Sistema Integrado de Bibliotecas da USP, em reunião de 20 de setembro de 1990. 
8. BASTOS, J.R.M. et al. Contribuição à posologia de dentifrícios pelo cirurgião dentista no Brasil. Rev Gaúcha Odont, v.33, n.3, p.202-5, jul./set. 1985.

9. BEN-AMAR, A. et al. Effect of mouthguard bleaching on enamel surface. Amer J Dent, v.8, n.1, p.29-32, Feb. 1995.

10.BITTER, N.C. A scanning electron microscopy study of the effect of bleaching agents on enamel: A preliminary report. J Prosthet Dent, v.67, n.6, p.8525, June 1992.

11.BOWLES, W.H.; UGWUNERI, Z. Pulp chamber penetration by hydrogen peroxide following vital bleaching procedures. J Endod, v.13, n.8, p.375-7, Aug. 1987.

12.BUCHALLA, W.; ATTIN, T.; HELLWIG, E. Brushing abrasion of luting cements under neutral acidic conditions. Oper Dent, v.25, p.482-7, 2000.

13. CARPINETTI, L.C.R. et al. Rugosidade superficial: conceitos e princípios de medição. São Carlos, Seção de Publicidade da EFESC-USP, 1996.

14. CHEN, J.H.; XU, J.W.; SHING, C.X. Decomposition rate of hydrogen peroxide bleaching agents under various chemical and physical conditions. J Prost Dent, v.69, n.1, p.46-8, Jan. 1993.

15. CIMILLI, H.; PAMEIJER, C.H. Effect of carbamida peroxide bleaching agents on the physical properties and chemical composition of enamel. Am J Dent, v.14, n.2, p.63-66, Apri 2001.

16. CHRISTENSEN, G.J. Bleaching vital tetracycline stained teeth. Quintessence Int, v.9, n. 6, p.13-9, 1978. 
17. COVINGTON, J.S. et al. Carbamide peroxide tooth bleaching: effects on enamel composition and topography. J Dent Res, v.69, p.175, 1990 labstract 530/.

18.DWINELLE, W.W. Ninth Annual Meeting of American Society of Dental Surgeons. Article X. Amer J Dent Sci, v.1, p.57-61, 1850.

19. ERNEST, C.P.; MARROQUIN, B.B.; ZONNCHEN, B.W. Effects of hydrogen peroxide-containing bleaching agents on the morphology of human enamel. Quintessence Int, v.27, n.1, p.53-6, Jan. 1996.

20. FISCHER, G. The bleaching of discolored teeth with $\mathrm{H}_{2} \mathrm{O}_{2}$. Dent Cosmos, v.53, p.246-7, Apr 1910.

21. FLOYD, R.A. The effect of peroxides and free radicals on body tissues. $\mathbf{J}$ Amer Dent Assoc, v.128, p.37S-40S, Apr 1997.

22. GARBER, D.A. Dentist-monitored bleaching: a discussion of combination and laser bleaching. J Amer Dent Assoc, v.128, p.26S-30S, Apr 1997.

23. GIOIA, T. Avaliação de quatro técnicas de clareamento para dentes não vitalizados: HI-LITE ativado por luz halógena, peróxido de hidrogênio ativado por laser de argônio, peróxido de hidrogênio ativado por espátula aquecida e "walking bleaching" - estudo, in vitro, em dentes bovinos. São Paulo, 2000. 142p. Dissertação (Mestrado) - Faculdade de Odontologia, Universidade de São Paulo.

24. GOLDSTEIN, R.E. In-office bleaching: where we came from, where we are today. J Amer Dent Assoc, v.128, p.11S-15S, Apr 1997. 
25. GRABENSTETTER, R.J. et al. The measurement of the abrasion of human teeth by dentifrice abrasives: a test utilizing radioactive teeth. J Dent Res, v.37, n.6, p.1060-8, Nov./Dec. 1958.

26.GULTZ, J. et al. Two in-office bleaching systems: a scanning electron microscope study. Comp Continuing Educ Dent, v.20, n.10, p.965-72, Oct. 1999.

27. HANKS, J.C. et al. Cytotoxicity and dentin permeability of carbamida peroxide and hydrogen peroxide vital bleaching materials, in vitro. J Dent Res, v.72, n.5, p.931-38, May 1993.

28. HARLAN, A.W. Proceeding of the American Dental Association: Twenty Third Annual Session. Dent Cosmos, v.26, n.7, p.97-8, 1884.

29. HARRINGTON, E. et al. Toothbrush-dentifrice abrasion. Brit Dent J, v.153, n.4, p.135-38, Aug. 1982.

30. HARTE, D.B.; MANLY, R.S. Effect of toothbrush variables on wear of dentin produced by four abrasives. J Dent Res, v.54, n.5, p.993-8, Sept./Oct. 1975.

31. HARTE, D.B.; MANLY, R.S. Four variables affecting magnitude of dentifrice abrasiveness. J Dent Res, v.55, n.3, p.322-7, May/June 1976.

32. HAYWOOD, V.B.; HEYMANN, H.O. Nightguard vital bleaching. Quintessence Int, v.20, n.3, p. 173-176, Mar. 1989.

33. HAYWOOD, V.B. et al. Nightguard vital bleaching: effects on enamel surface texture and diffusion. Quintessence Int, v. 21, n.10, p. 801-4, Oct. 1990. 
34.HAYWOOD, V.B.; HOUCK, V.M.; HEYMANN, H.O. Nightguard vital bleaching: effects of various solutions on enamel surface texture and color. Quintessence Int, v. 22, n.10, p. 775-82, Oct. 1991.

35. HAYWOOD, V.B. History, safety, and effectiveness of current bleaching techniques and applications of the nightguard vital bleaching technique. Quintessence Int, v. 23, n.7 p. 471-85, 1992.

36. HAYWOOD, V.B. Nightguard vital bleaching: current concepts and research. J Amer Dent Assoc, v. 128, p.19s-25s, Apr 1997.

37. HEATH, J.R.; WILSON, H.J. Abrasion of restorative materials by toothpaste. J Oral Rehabil, v.3, n.2, p.121-138, May 1975.

38. HEFFERREN, J.J. A laboratory method for assessment of dentifrice abrasivity. J Dent Res, v.55, n.4, p.563-73, July/Aug. 1976.

39. HONÓRIO, H.M. Avaliação do desgaste de diferentes métodos de profilaxia sobre o esmalte bovino hígido e desmineralizado. Bauru, 2003. 70p. Dissertação (Mestrado) - Faculdade de Odontologia de Bauru, Universidade de São Paulo.

40. HOSOYA, N. et al. Changes in enamel surface roughness and adhesion of Streptococcus mutans to enamel after vital bleaching. J Dent, v.31, p.5438, 2003.

41.HUNSAKER, K.J.; CHRISTENSEN, G.J.; CHRISTENSEN, R.P. Tooth bleaching chemicals: influence on teeth and restorations J Dent Res, v.69, p.303, 1990 /Abstract1558/. 
42. INTERNATIONAL ORGANIZATION FOR STANDIZATION. Technical specification 14569-1. Dental materials: Guidance on testing of wear resistance. Part 1: wear by tooth brushing. Switzerland, ISO, 1999.

43. JOSEY, A.L. et al. The effect of a vital bleaching technique on enamel surface morphology and the bonding of composite resin to enamel. J Oral Rehab v.23, n.4, p.244-50, Apr. 1996.

44.JUNQUEIRA, J.C. et al. Efeito da técnica de clareamento utilizando peróxido de carbamida a 35\%, sobre o esmalte dental - avaliação por microscopia de luz polarizada e microscopia eletrônica de varredura. JBC, v.4, n.24, p. 61-5, nov./dez. 2000.

45. KALLILI, T.; et al. Toothbrush abrasion and bond strength of bleaching enamel. J Dent Res, v.70, p.546, 1991 /Abstract 2243/.

46. KINGSBURY, C.A. Discoloration of dentine. Dent Cosmos, v.3, n.2 p.57-60, Sept. 1861.

47.KIRK, E.C. The chemical bleaching of teeth. Dent Cosmos, v.31, p.273-5, 1889.

48. KUTSCH, V.K. Lasers in dentistry: comparing wavelengths. J Amer Dent Assoc, v. 124, p. 49-54, Feb. 1993.

49. KWON, Y.H., et al. Effects of hydrogen peroxide on the light reflectance and morphology of bovine enamel. J Oral Rehabil, v.29, p.473-7, 2002.

50. LEE, C. ET AL. Effect of bleaching on microhardness, morphology and color enamel. Gen Dent, v.43, n.2, p.158-62, April 1995. 
51.LEONARD JUNIOR., R.H.; BENTLEY, C.D.; HAYWOOD, V.B. Salivary pH changes during 10\% carbamide peroxide bleaching. Quintessence Int, v.25, n.8, p.547-50, Aug. 1994.

52. LYNCH, E. et al. Molecular mechanisms of the bleaching actions associated with commercially-available whitening oral health care products. J Ir Dent Assoc, v.41, n.4, p. 94-102, 1995.

53. LORENZO, J.A. et al. Clinical study of a halogen light-activated bleaching agent in nonvital teeth: case reports. Quintessence Int, v.27, n.6, p.3838, June 1996.

54.MANNING, R.H.; EDGAR, W.M. Intra-oral models for studying de- and remineralization in man: methodology and measurement. J Dent Res, v.71, p.895-900, Apr. 1992. Special issue.

55. MCCRACKEN, M.S.; HAYWOOD, V.B. Demineralization effects of $10 \%$ carbamide peroxide. J Dent, v.24, n.6, p.395-8, Nov. 1996.

56. McEVOY, S. Chemical agents for removing intrinsic stains from vital teeth. II. Current techniques and their clinical application. Quintessence Int, v.20, n.6, p. 379-84, June 1989.

57. McGUCKIN, R.S.; BABIN, J.F.; MEYER, B.J. Alteration in human enamel surface morphology following vital bleaching. J Prosthet Dent, v.68, n.5, p.754-60, Nov. 1992.

58. MELLBERG, J.R. Hard-tissue substrates for evaluation of cariogenic and anticariogenic activity in situ. J Dent Res, v.71, p.913-9, Apr. 1992. Special Issue. 
59. MENEZES, M.M.; FIROOZMAND, L.M.; HUHTALA, M.F.R. Avaliação do desgaste superficial do esmalte escovado com dentifrícios e submetido à ação de agentes branqueadores. Cienc Odontol Brás, v.6, n.1, p.44-50, jan./mar. 2003.

60. MILLER, W.D. Experiments and observations on the wasting of tooth tissue variously designated as erosion, abrasion, chemical abrasion, denudation, etc. Dent Cosmos, v.49, n.1, p.1-23, Jan. 1907.

61. MONDELLI, R.F.L. Clareamento dental. Rev Dent Rest, v.1, n.4, out./nov. 1998.

62. MONDELLI, R.F.L. Clareamento de dentes polpados: técnicas e equipamentos. Rev Odontol Biodonto, v.1, n.1, p. 10-71, jan./fev. 2003.

63. MOTTA, L.G. et al. Análise do conteúdo abrasivo de dentifrícios. Rev ABO Nac, v.6, n.3, p.147-8, jun./jul. 1998.

64. NAVARRO, M.F.L.; MONDELLI, R.F.L. In: Odontologia estética. Riscos com o clareamento dental. São Paulo: Ed. Santos, 2002. Cap. 20, p. 397-418.

65.PASHLEY, D.H.; THOMPSON, S.M.; STEWART, F.P. Dentin permeability: effects of temperature on hydraulic conductance. J Dent Res, v.62, n.9, p.956-9, Sept. 1983.

66. PIMENTA, L.A.F.; et al. Efeito da utilização in vitro de agentes clareadores de consultório na rugosidade superficial do esmalte. Pesqui Odontol Brás, v. 17, p.188. Suplemento /Abstract Pb244 Apresentado na $20^{a}$ Reunião Anual da SBPqO, Lindóia 2003/. 
67. PINHEIRO JUNIOR, E.C. et al. In vitro action of various carbamide peroxide gel bleaching agents on the microhardness of human enamel. Braz Dent J, v.7, n.2, p.75-9, Feb. 1996.

68. REDMALM, G.; RYDÉN, H. Dentifrice abrasivity. Swed Dent J, v.3, p.91100, 1979.

69. REYTO, R. Laser tooth whitening. Dent Clin North Amer, v.42, n.4, p.75562, Oct. 1998.

70. RIEHL, H. Estudo in vitro do efeito de três diferentes agentes clareadores sobre a dureza e rugosidade do esmalte dentário bovino. Bauru, 2002. Tese (Doutorado) - Faculdade de Odontologia de Bauru, Universidade de São Paulo. 102p.

71.RIOS, D. et al. Wear and superficial roughness of glass ionomer cements used as sealants, alter simulated toothbrushing. Pesqui Odontol Bras, v.16, n.4, p.343-8, 2002.

72.ROTSTEIN, I.; TOREK, Y.; LEWINSTEIN, I. Effect of bleaching time and temperature on the radicular penetration of hydrogen peroxide. Endod Dent Traumat, v.7, n.5, p.196-8, Oct.1991.

73. SATO, I. et al. Comparison between deciduous and permanent incisor teeth in morphology of bovine enamel. Okajimas Folia Anat Jap, v.76, n.2-3, p.131-5, 1999.

74.SERRA, M,C.; CURRY, J.A. The in vivo effect of glass-ionomer cement restoration on enamel subjected to a demineralization and demineralization model. Quintessence Int v.24, n.2, p.143-7, 1992. 
75. SEXSON, J.C.; PHILLIPS, R.W. Studies on the effects of abrasives on acrylic resins. J Prosthet Dent, v.1, n.4, p. 454-71, July 1951.

76.SHANNON, H.; et al. Characterization of enamel exposed to $10 \%$ carbamida peroxide bleaching agents. Quintessence Int, v.24, n.1, p.39-44, 1993.

77. SPALDING, M. Estudo "in vitro" do aspecto morfológico da superfície do esmalte e alteração na permeabilidade dentária após clareação. Bauru, 2000, 137p. Dissertação (Mestrado) - Faculdade de Odontologia de Bauru, Universidade de São Paulo.

78.STOOKEY, G.K.; MUHLER, J.C. Laboratory studies concerning the enamel and dentin abrasion properties of common dentifrice polishing agents. $\mathbf{J}$ Dent Res, v.47, n.4, p.524-32, July/Aug. 1968.

79. SULIEMAN, M.; et al. A safety study in vitro for the effects of an in-office bleaching system on the integrity of enamel. J Dent, v.32, p.581-90, 2004.

80.TITLEY, K.C.; TORNECK, C.D.; SMITH, D. The effect of concentrated hydrogen peroxide solutions on the surface morphology of human tooth enamel. J Endod, v.14, n.2, p.69-74, Feb. 1988.

81.TURSSI, C.P. Micromorfologia superficial de materiais estéticos submetidos a diferentes processos de degradação. Piracicaba, 2001. Dissertação (Mestrado). Faculdade de Odontologia de Piracicaba Universidade Estadual de Campinas.

82. WORSCHECH, C.C. et al. In vitro evaluation of human dental enamel surface roughness bleached with 35\% carbamide peroxide and submitted to abrasive dentifrice brushing. Pesqui Odontol Bras, v.17, n.4, p.342-8, out./dez. 2003. 
83. ZALKIND, M. et al. Surface morphology changes in human enamel, dentin and cementum following bleaching: scanning electron microscopy study. Endod Dent Traumat, v.12, n.2, p.82-8, Apr. 1996.

84.ZANIN, F.; et al. Clareamento dental com luz laser e LED. RGO, v.51, n.3, p.143-6, Jul./Set. 2003. 
ABSTRACT

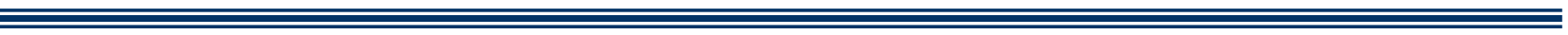




\section{ABSTRACT}

The purpose of this study was to evaluate the surface roughness and wear of bovine enamel submitted to three different bleaching techniques (two in-office and one home bleaching) and simulated brushing. Enamel fragments $(1.5 \mathrm{~cm} \times 0.5 \mathrm{~cm}$ and $0.4 \mathrm{~cm}$ high) were obtained. Half of each specimen was treated with a bleaching agent and submitted to simulated brushing, and the other half was used as control. The specimens were polished and five readings of initial surface roughness were carried out using a perfilometer (Hommel Tester $T$ 1000). The average surface roughness $(\mathrm{Ra})$ was obtained. The specimens were randomly divided into 4 groups ( $n=10$ ) according to treatment: $\mathrm{G} 1=$ artificial saliva (control); G2= 35\% hydrogen peroxide (HP) (Lase Peroxide, DMC Equipments), activated with a hybrid light (LED and Diode laser) Ultrablue IV (DMC Equipments); G3= 35\% HP (Lase Peroxide) activated with halogen light (Curing Light-3M ESPE). The 35\% hydrogen peroxide agent was applied on the enamel surface for three consecutive times; G4= 16\% PC bleaching agent (Whiteness Perfect, FGM) for 2 hours daily during 14 days. The samples were stored in artificial saliva for the remaining time. After bleaching treatment, the surface roughness (Ra) was measured and the specimens were stored in artificial saliva for 7 days, and then subjected to 100,000 cycles of simulated brushing. The final roughness (Ra) was determined and three readings of superficial wear were carried out (Hommel Tester $\mathrm{T}$ 1000). The superficial roughness average values were statistically analyzed by two-way ANOVA and Tukey test. There were no significant differences among groups comparing initial and pos-bleaching roughness. After brushing, there were significant differences between control group and experimental groups. G4 showed a significant increase in roughness values compared to G2. Wear was significantly less for G1 compared to other groups (one-way ANOVA and Tukey test). Bleaching techniques promote increased bovine enamel surface roughness and superficial wear, when submitted to simulated brushing. 